\title{
Geologic Map of the Cochetopa Park and North Pass Calderas, Northeastern San Juan Mountains, Colorado
}

\author{
By Peter W. Lipman
}

Pamphlet to accompany

Scientific Investigations Map 3123

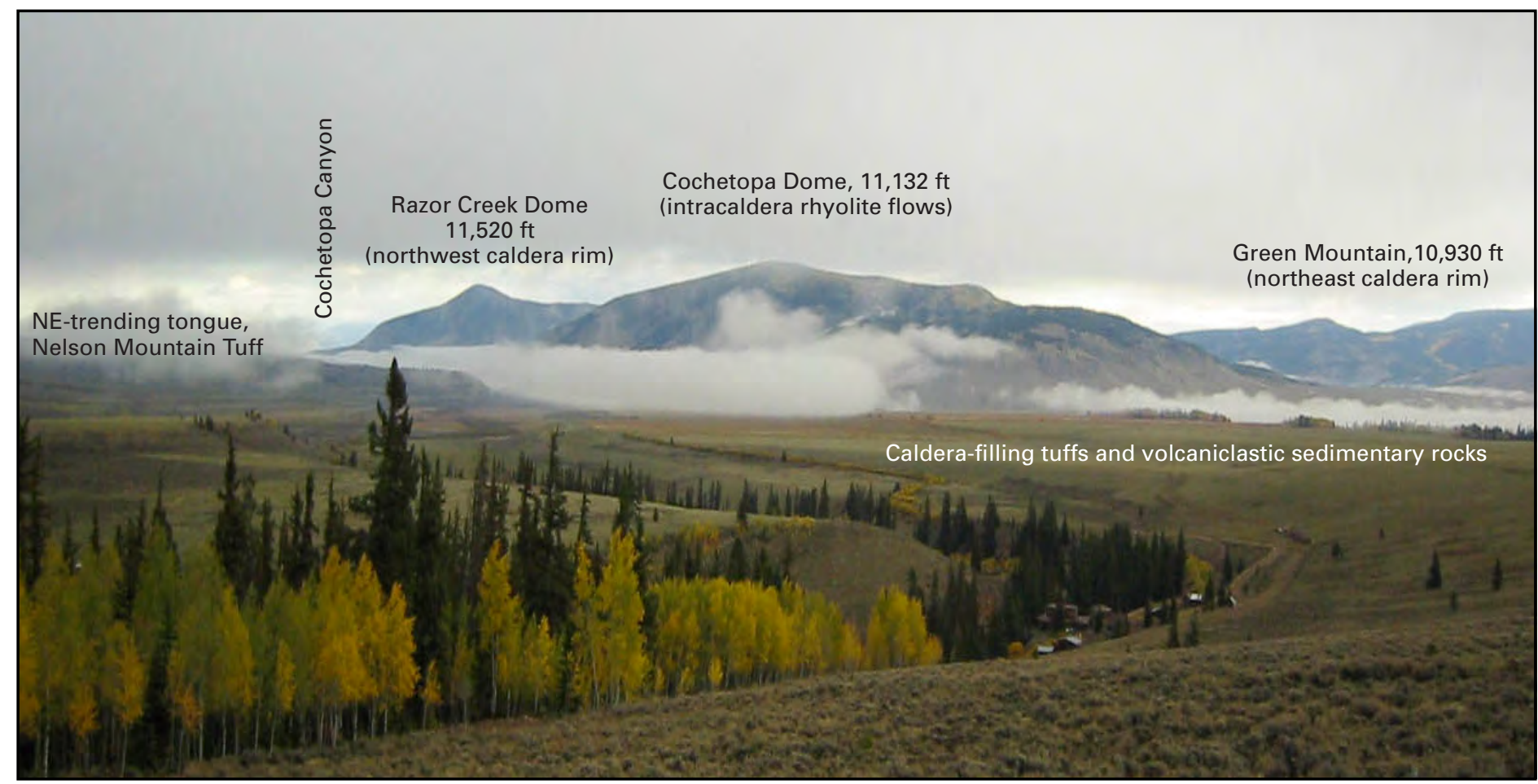

Panoramic view of Cochetopa Dome (sequence of rhyolitic lava flows within caldera) and north walls of Cochetopa Park caldera, viewed from south. Cloud-obscured northwest caldera rim, at left of image, is Sawtooth Mountain $(12,147 \mathrm{ft})$; northeast caldera rim is marked by Razor Creek Dome and Green Mountain on right side. Light-colored eroding outcrops in foreground are weakly indurated tuff and volcaniclastic sedimentary fill of the caldera basin. 
This page intentionally left blank 


\section{CONTENTS}

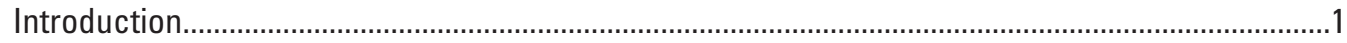

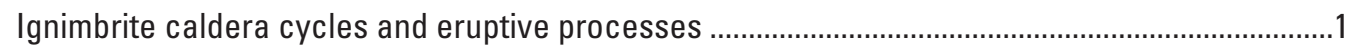

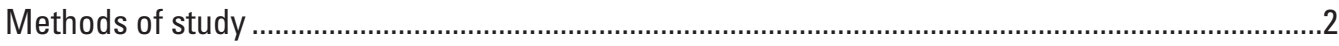

Regional framework

Early northern volcanism along the Sawatch trend .................................................................

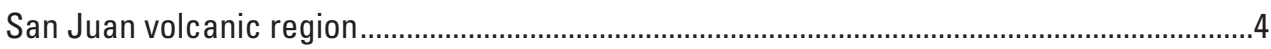

Early lavas and intrusions: Saguache-Cochetopa region (35-32 Ma) ..............................................

Saguache Creek Tuff and North Pass caldera cycle (32.2 Ma) .....................................................

Precursor(?) lavas (32.2 Ma) and tuff of Spanish Creek (32.5 Ma) ...........................................

Saguache Creek Tuff (32.25 Ma) ...........................................................................................

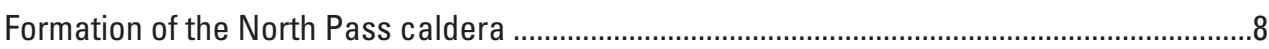

Caldera-filling lavas (volcanics of Cochetopa Hills, $32.2 \mathrm{Ma}$ ) .................................................

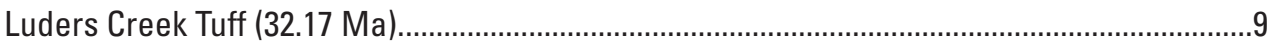

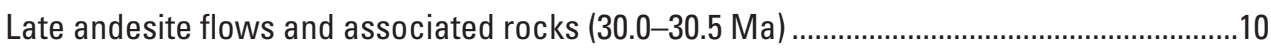

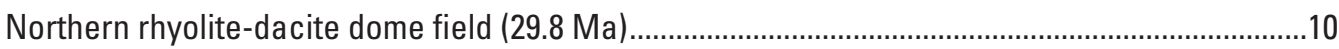

Younger eruptions from other San Juan calderas (28.3-26.9 Ma)................................................11

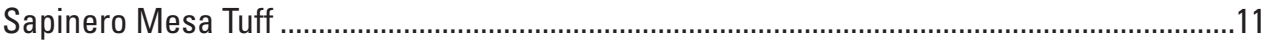

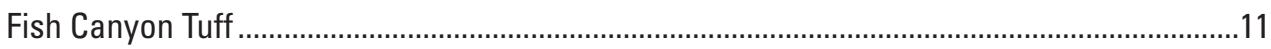

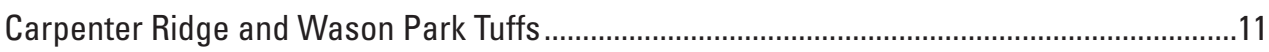

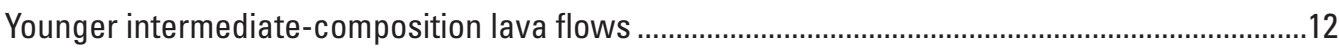

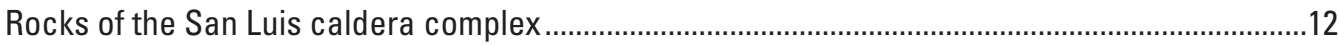

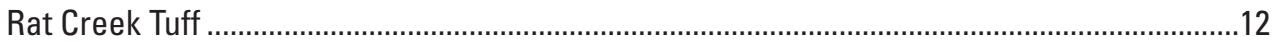

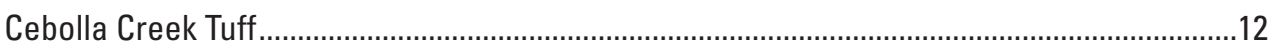

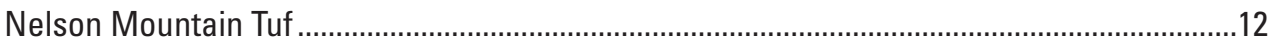

Cochetopa Park caldera: Relation to Nelson Mountain Tuff (26.9 Ma)................................13

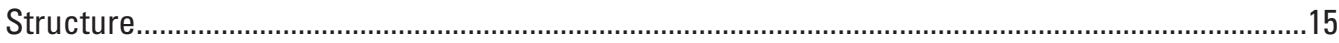

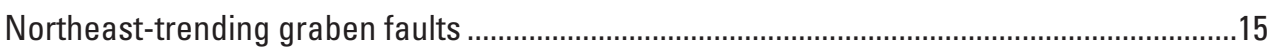

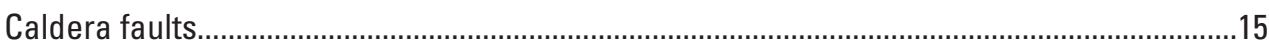

Rio Grande rift faults and associated volcanism.................................................................

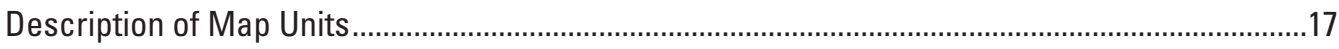

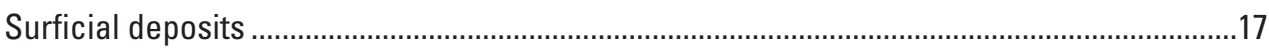

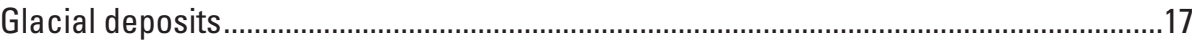

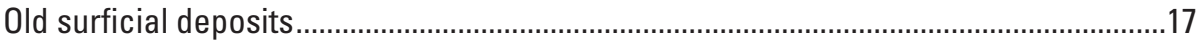

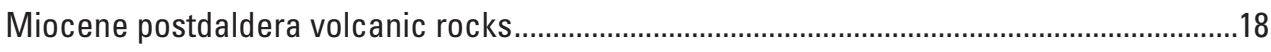

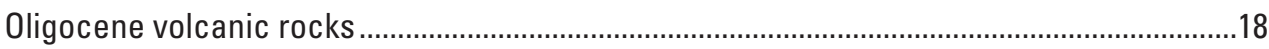

Rocks of Cochetopa Park caldera and San Luis caldera complex .................................18

Rocks of the Nelson Mountain caldera cycle.......................................................18

Caldera-fill flows and intrusions ...................................................................18

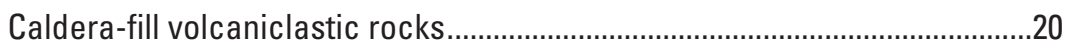

Nelson Mountain Tuff...................................................................................21

Rocks erupted from the Cebolla Creek caldera.....................................................22

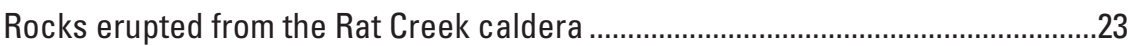

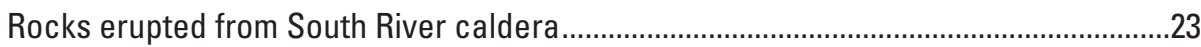

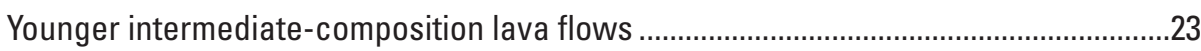

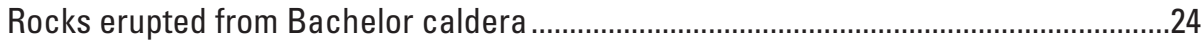

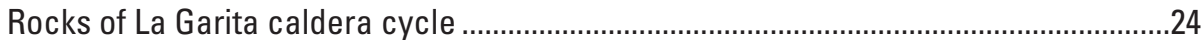

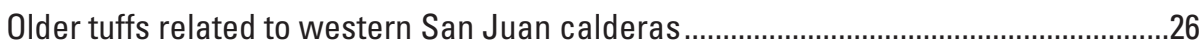

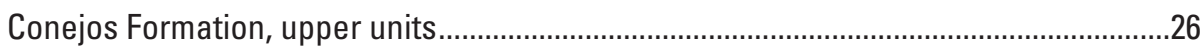


Caldera-related rocks predating the western and central caldera clusters...................28

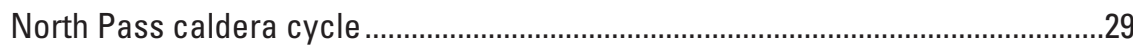

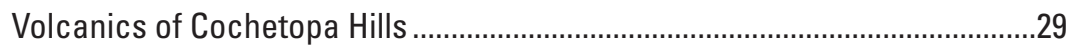

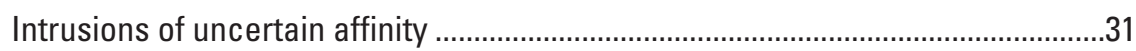

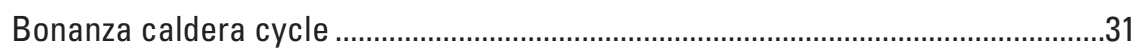

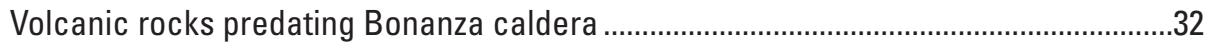

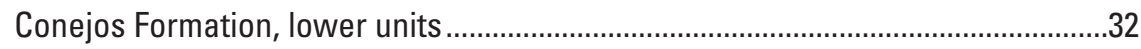

Early ignimbrites erupted from Sawatch Range calderas .............................................34

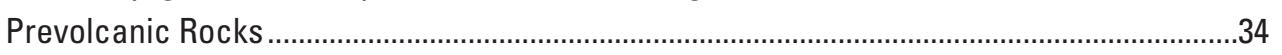

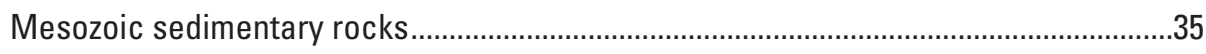

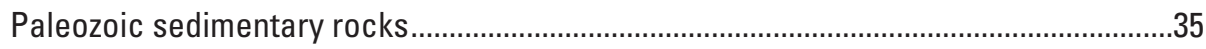

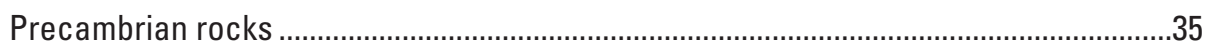

References Cited

Figures

1. Map of Southern Rocky Mountain volcanic field .......................................................sheet 2

2. Map showing calderas in San Juan volcanic region and location of map area .......sheet 2

3. Map showing northeastern San Juan region and geologic mapping responsibilities.

sheet 1

4. Generalized geologic map and section, northeast San Juan region ..........................sheet 2

5. Oblique view (Google Earth) of Cochetopa and North Pass calderas.............................eet 2

6. Summary of ${ }^{40} \mathrm{Ar} /{ }^{39} \mathrm{Ar}$ age determinations............................................................................. 2

7. Age-distance-volume plot.......................................................................................sheet 2

8. Photograph showing east wall of North Pass caldera...............................................sheet 2

9. Schematic east-west stratigraphic section, along Saguache valley into the North Pass caldera sheet 2

10. Generalized geologic map of San Luis complex in relation to Cochetopa Park caldera....... sheet 2

Tables

1. Regional ignimbrites and calderas of the Southern Rocky Mountain Volcanic Field ........41

2. Summary of new ${ }^{40} \mathrm{Ar} /{ }^{39} \mathrm{Ar}$ age determinations for Tertiary volcanic rocks ........................42

3. Compilation of ${ }^{40} \mathrm{Ar} /{ }^{39} \mathrm{Ar}$ age determinations for Tertiary volcanic rocks

CD-ROM

4. Representative chemical analyses of Tertiary volcanic rocks ...........................................4

5. Compilation of chemical analyses of Tertiary volcanic rocks....................................ROM

6. Characteristic features of ignimbrite sheets in the central and northeastern San Juan

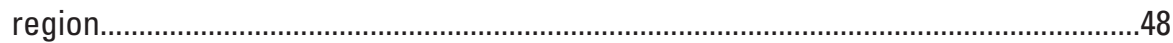




\section{Introduction}

The San Juan Mountains in southwestern Colorado (fig. 1, sheet 2) have long been known as a site of exceptionally voluminous mid-Tertiary volcanism (Cross and Larsen, 1935; Larsen and Cross, 1956), including at least 22 major ignimbrite sheets (each 150-5,000 $\mathrm{km}^{3}$ ) and associated caldera structures active at 33-23 Ma (fig. 2, sheet 2; table 1, Steven and Ratté, 1965; Lipman and others, 1970; Steven and Lipman, 1976). Recent volcanologic and petrologic studies in the San Juan region have focused mainly on several ignimbrite-caldera systems: the southeastern area (Platoro complex: Lipman, 1975; Dungan and others, 1989; Lipman and others, 1996), western calderas (Uncompahgre-Silverton-Lake City: Lipman and others, 1973; Hon and Lipman, 1989; Bove and others, 2001), and the central cluster (La Garita-Creede calderas: Lipman and others, 1989, 1997; Riciputi and others, 1995; Lipman, 2000, 2006; Schmitz and Bowring, 2001; Bachmann and others, 2002, 2007; Parat and others, 2005).

Far less studied has been the northeastern San Juan region (fig. 2), which occupies a transition between earlier volcanism in central Colorado and large-volume younger ignimbrite-caldera foci farther south and west (fig. 1). Other than mineral-resource studies of small areas, much of this northeastern area previously had been mapped only in broad reconnaissance for the Colorado State geologic map (Tweto and others, 1976; Tweto, 1979). The present map is based on new field coverage of volcanic rocks in seventeen 7.5' quadrangles in northeastern parts of the volcanic field (fig 3, sheet 1 ; fig. 4, sheet 2), high-resolution age determinations for 120 new sites (table 2; table 3, CD-ROM; Lipman and McIntosh, 2008), and petrologic studies involving several hundred new chemical analyses (table 4; table 5, CD-ROM). Among topics explored are previously little-understood complexities of pyroclastic eruption and emplacement, geometric interrelations between caldera subsidence and resurgence, petrologic diversity of sequential ignimbrite eruptions, recurrent eruption of intermediate-composition lavas after caldera-forming events, associated regional fault development, volume relations between ignimbrite eruptions and associated calderas, growth of subvolcanic batholiths, and involvement of mantle-derived mafic materials in magma-generation processes. This mapping and the accompanying lab results (1) document volcanic evolution of the previously unrecognized North Pass caldera and the morphologically beautifully preserved but enigmatic Cochetopa basin (fig. 5, sheet 2), including unique features not previously described from ignimbrite calderas elsewhere; (2) provide evidence for a more rapid recurrence of large ignimbrite eruptions than previously known elsewhere; (3) quantify the regional time-space-volume progression from the earlier Sawatch magmatic trend southward into the San Juan region; and (4) permit more rigorous comparison between the broad mid-Tertiary magmatic belt in the western U.S. Cordillera and the type continental-margin arc volcanism in the central Andes.

This pamphlet is intended (1) to provide a guide to the geologic evolution of the Cochetopa and North Pass calderas (modified from Lipman and McIntosh, 2008) within a conceptual framework of caldera processes and the regional setting for these newly interpreted caldera systems within the Southern Rocky Mountain volcanic field of mid-Tertiary age (Lipman, 2007) and (2) to offer brief descriptions for each of the 100-plus rock units depicted on the accompanying geologic map.

\section{Ignimbrite Caldera Cycles and Eruptive Processes}

As previously interpreted for silicic volcanism in the San Juan Mountains and elsewhere, lavas, volcaniclastic sedimentary rocks, and intrusions emplaced concurrently with ignimbrites in the northeastern San Juan region define multiple caldera cycles, based on affinities of geographic distribution and stratigraphic sequence, isotopic age and paleomagnetic pole positions, and petrologic character. Interpretation of some units remains ambiguous, especially assignment of certain lavas and tuffs to the late stages of one cycle versus inception of the next one. The revised analysis of caldera development and regional volcanic history (table 1) builds upon earlier syntheses for the San Juan region (Lipman and others, 1970, 1978; Steven and Lipman, 1976; Lipman, 2000), utilizing general concepts of caldera geometry and eruptive cycles summarized by Smith and Bailey (1968) and Lipman (1984, 1997, 2007). These overview papers provide a framework for broader understanding of the map relations depicted on this map.

Briefly, many large ignimbrite calderas, such as those in the San Juan region, form at sites of preceding volcanism that records shallow accumulation of caldera-related magma. Large eruptions ( $>50-100 \mathrm{~km}^{3}$ of ignimbrite magma) cause caldera collapse concurrently with volcanism, as indicated by thick intracaldera ignimbrite fill and interleaved collapse slide breccias. Volumes of intracaldera and outflow tuff tend to be subequal; correlation between them is commonly complicated by contrasts in abundance and size of phenocrysts and lithic fragments, degree of welding, devitrification, alteration, and even chemical composition of magmatic material. Structural boundaries of calderas commonly are single ring faults or composite ring-fault zones that dip steeply. Scalloped topographic walls beyond the structural boundaries of most calderas are due to secondary gravitational slumping during subsidence. The area and volume of caldera collapse are roughly proportional to the amount of erupted material. Postcollapse volcanism may occur from varied vent geometries within ignimbrite calderas; ring-vent eruptions are most common in resurgent calderas, reflecting renewed magmatic pressure. Resurgence within calderas may result in a symmetrical dome or more geometrically complex forms. In addition to resurgence within single calderas, broader magmatic uplift occurs within some silicic volcanic fields, reflecting isostatic adjustment to emplacement of associated subvolcanic batholiths. Large intrusions related to resurgence are exposed centrally or along the margins of some deeply eroded calderas. Hydrothermal activity and mineralization accompany all stages of ignimbrite magmatism, becoming dominant late during caldera evolution. Much rich mineralization formed millions of years later than caldera collapse, when 
the caldera served primarily as a structural control for late intrusions and associated hydrothermal systems.

\section{Methods of Study}

Geologic mapping, initiated to characterize the geologic setting for the Creede Scientific Drilling Project (Bethke and Hay, 2000), was gradually expanded to cover the entire central caldera cluster and adjacent areas to the northeast as multiple stratigraphic, structural, geochronologic, and volcanologic problems emerged (fig. 2). In addition to the published geologic map of the central San Juan caldera complex (Lipman, 2006), field study of the Cochetopa and North Pass caldera areas by Lipman totaled about 30 weeks, mainly between 2000 and 2005; assistance during initial fieldwork was provided by Joel Robinson (2000) and Pierre Christe (2001). Continuing field studies (starting in 2006) farther to the east are focused on interpretation of the Bonanza caldera system (fig. 4) and a newly identified caldera fragment exposed east of the Continental Divide that probably continues into upper Marshall Creek (Gregory and McIntosh, 1996). Small parts of the map area, especially preTertiary rocks in northwestern quadrangles, were recompiled from published maps (Hedlund and Olson, 1974; Olson and others, 1975; Olson, 1976a,b; Olson and Steven, 1976a,b); all Tertiary volcanic rocks and other areas that required significant reinterpretation were remapped (fig. 3). Fieldwork and primary map compilation were at a scale of 1:24,000, using 7.5' topographic quadrangle maps as base materials (fig. 3); these data are included as digital files in the database accompanying this report. In total, 102 map units are distinguished. Most of the fieldwork preceded use of GPS for locations; some Quaternary deposits in flat-lying areas were compiled by photogrammetric methods. Two recently mapped 7.5' quadrangles (Stork and others, 2006, 2007) are adjacent to the northwest corner of the map area.

The digital files were compiled using ArcMap GIS software, mainly by Joel Robinson. The geologic map data were transferred to the 1:50,000-scale county map series by GIS methods to provide a more legible base than would have been possible by photo reduction of the 1:24,000-scale quadrangle maps. In the Description of Map Units, needed references to map locations are by abbreviations of the 7.5' quadrangle names, as listed on figure 3; for example, the Cochetopa Park quadrangle is referenced as CP. Some unit descriptions, age determinations, and geologic interpretations are based partly on features from adjacent quadrangles to the south (Lipman, 2006) or east (Bonanza area, fieldwork in progress) of the map area (fig. 3); these are also referenced by quadrangle abbreviations where appropriate.

Volcanic rock names are used in general accord with the IUGS classification system (Le Bas and others, 1986); in particular, the term "silicic dacite" is used for rocks designated quartz latite in many prior publications. Most of the volcanic rocks constitute a high- $\mathrm{K}$ assemblage that is transitional between subalkaline and alkaline suites, similar to those at other Tertiary volcanic fields in the Southern Rocky Mountains. For simplicity and continuity with previous usage, such modifiers as "high-K" or "trachy" are omitted from most rock names. Names, divided on the basis of percent $\mathrm{SiO}_{2}$, are $<52$, basalt; 52-57, basaltic andesite; 57-62, andesite; 62-66, dacite; 66-70, silicic dacite (formerly quartz latite); 70-75, rhyolite; $>75$, silicic rhyolite (all compositions for bulk-rock analyses recalculated to reported summations volatile-free, all $\mathrm{FeO}$ as $\mathrm{Fe}_{2} \mathrm{O}_{3}$ ). Phenocryst assemblages distinguish many of the major ignimbrite sheets (table 6). Cited chemical and petrographic data include 130 new majoroxide and trace-element analyses for samples from the map area (table 4; table 5, CD-ROM), supplemented by data for regional units from Lipman (2004). Sanidine compositions, initially determined from $\mathrm{x}$-ray cell parameters (Lipman, 1975) and later by electron-microprobe analysis (Lipman and Weston, 2001; Lipman, unpub. data, 2000-2007), have also provided useful discriminants to test correlations among some ignimbrite sheets. Mineral-chemical data for other phenocrysts (biotite, augite) show less variation among San Juan ignimbrites.

Critical to many of the interpretations presented here is the large array (120 localities; in total, 125 mineral and groundmass ages, table 3, CD-ROM) of new high-resolution ${ }^{40} \mathrm{Ar} /{ }^{39} \mathrm{Ar}$ age determinations for volcanic rocks in the San Juan region (Lipman and McIntosh, 2008). Age results for sites within the northeastern San Juan map area (81 samples) are plotted on the map. Especially useful have been single-crystal laser-fusion ages (SCLF) on sanidine phenocrysts, obtained wherever this phase was present; additional determinations are incrementalheating plateau ages for biotite and hornblende phenocrysts and for groundmass concentrates from lavas lacking datable phenocryst phases. The ages were determined at the New Mexico Geochronology Research Laboratory by methods similar to those described in McIntosh and Chapin (2004). Multiple samples were dated for most major volcanic units to evaluate correlations and to improve precision of pooled ages. For most single-crystal laser-fusion ages, 10-15 feldspar grains were analyzed for each site; as many as 36 grains were dated for a few stratigraphically critical sites. All new and previously published ages are calibrated to Fish Canyon Tuff at 28.02 Ma. Analytical uncertainties for individual samples are reported to two standard deviations ( $95 \%$ confidence level); pooled sanidine ages for multiple sites from a single unit are listed as weighted means, with uncertainties as the standard error (Se). Interpreted preferred ages (table 2; fig. 6, sheet 2) are influenced by stratigraphic relations, supplemented by additional age determinations from beyond the map area; interpretive problems with ages for some units are discussed in Lipman (2000) and Lipman and McIntosh (2008).

Cited paleomagnetic-pole directions for the San Juan rocks are from published sources (Tanaka and Kono, 1973; Diehl and others, 1974; Rosenbaum and others, 1987; Lipman and McIntosh, 2008).

In addition to the data summarized in the pamphlet, complete analytical results for the new ${ }^{40} \mathrm{Ar} r{ }^{39} \mathrm{Ar}$ determinations, whole-rock chemistry of volcanic units present in the northeastern San Juan region, and supplemental photographs of major rock units and caldera features are included on the CD-ROM that accompanies the printed report or at 
http://pubs.usgs.gov/sim/3123/. Successful completion of fieldwork and interpretations of the caldera history have been strongly dependent on the productive multi-year collaborative studies with William McIntosh of the New Mexico Institute of Mining and Technology, principle results of which have been reported elsewhere (Lipman and McIntosh, 2008). In addition to technical collaboration with numerous other geologists, as noted or referenced in this report, I also thank many friends in the San Juan region who provided diverse hospitality, logistical support, help with back-country and property access, and other assistance during fieldwork: especially John and Patty Judson of Quarter-Circle Circle Ranch in Cochetopa Park; Billy, Curt, and Lee Ann Cadwell of Cathedral Creek Ranch; Robert Sharp of the Old Agency Ranch along Los Pinos Creek; and Pip and Aaron Conrad of the Rafiki Ranch near Villa Grove.

\section{Regional Framework}

Mid-Tertiary volcanic deposits once formed continuous cover across much of the Colorado Rocky Mountains and into northern New Mexico (fig. 1), constituting a composite Southern Rocky Mountain volcanic field (SRMVF), for which the San Juan region is the largest erosional remnant (Steven, 1975; Lipman, 2007). Subareas of the SRMVF, dismembered by subsequent erosion, have commonly been described as multiple separate volcanic fields (San Juan, Sawatch, Thirtynine Mile, Latir, West Elk, Central Colorado, and others) rather than as time-space transgressive magmatic foci within a large composite field.

Activity in the SRMVF peaked between 37 and $26 \mathrm{Ma}$ (McIntosh and Chapin, 2004; Lipman, 2007; Lipman and McIntosh, 2008). Dominantly intermediate-composition lavas and breccias (andesite-dacite) erupted from widely scattered central volcanoes were characteristic early phases of SRMVF activity. Major volcanic foci, initially established by clustered stratocones, became eruption sites for about 30 caldera-associated ignimbrites of more silicic compositions (table 1; fig. 7, sheet 2), in response to increased magmatic input focused at these sites. Composite volumes of the earlyintermediate volcanoes are large; in the San Juan region stratigraphic sequences commonly are more than a kilometer thick, and total volume, estimated at $25,000 \mathrm{~km}^{3}$ (Lipman and others, 1970), exceeds that of the later-erupted ignimbrites by about 50 percent.

The original areal extent of the overall SRMVF appears to have exceeded $100,000 \mathrm{~km}^{2}$, with a total volume of volcanic deposits greater than $50,000 \mathrm{~km}^{3}$ (Lipman, 2007). Peak magmatic volumes in the SRMVF, associated with ignimbrite eruptions, define a general (if imperfect) progression (fig. 7) from early eruptions along the Sawatch Range in central Colorado (37-33 Ma; McIntosh and Chapin, 2004), southward into the San Juan region (32-27 Ma; Lipman and others, 1970), and later to the 25-Ma Latir-Questa magmatic center in northern New Mexico (Lipman, 1988; Johnson and others, 1989) and the 23-Ma Lake City caldera in the far western San Juan Mountains (Lipman, 1976; Bove and others, 2001).
Mid-Tertiary volcanic rocks of the northeastern San Juan Mountains lie along the broad boundary between Precambriancored uplifts of the Southern Rocky Mountains, which formed by contraction during low-angle plate subduction in Late Cretaceous and Early Tertiary time, and less-deformed Paleozoic and Mesozoic sedimentary rocks along the northeast flank of the Colorado Plateau. These differences in geologic setting exerted important controls on structural and morphologic evolution during volcanism. To the south and west in the San Juan region, ignimbrite volcanism generated a well-stratified plateau, interrupted by local complexities associated with calderas. The original mid-Tertiary volcanic terrain was much like the Altiplano of the central Andes, because voluminous eruptions buried and subdued most of the pre-existing topography. In contrast, northeastern parts of the San Juan volcanic accumulation lap onto rugged paleotopography associated with earlier Tertiary uplifts of the Southern Rocky Mountains. Valleys, developed during erosion of the early Tertiary uplifts and during the growth of central volcanoes prior to large ignimbrite eruptions, strongly influenced the distribution of subsequently emplaced volcanic deposits (Chapin and Lowell, 1979; Steven and others, 1995). Some major paleovalleys survived the entire period of volcanism, and many present-day San Juan drainages are directly inherited from the mid-Tertiary landscape, leading to our fieldwork expression "once a valley, always a valley." Most conspicuous within the map area is the course of lower Saguache Creek, which empties into the San Luis Valley at the town of Saguache (fig. 4). This modern drainage coincides with a broad paleovalley between Oligocene stratocones to the north and south. All the major Oligocene ignimbrites of the region were deposited preferentially along this paleovalley. Similarly, the present-day basin of Cochetopa Park is similarly inherited morphology from an Oligocene caldera.

Exposed pre-Tertiary rocks also provide useful information on paleotopography at the inception of volcanism and subsequent events. Notably, small windows of Precambrian granite, but no Mesozoic sedimentary rocks, are exposed around margins of the North Pass caldera, showing that this caldera formed within a prevolcanic highland, probably a southern continuation of the Sawatch Range uplift of Late Cretaceous age. In eastern parts of the map area, considerable paleorelief existed on the Precambrian rocks prior to burial by Tertiary volcanism. Farther west and north, gently dipping Mesozoic sedimentary rocks are widely present beneath the volcanic cover, reflecting proximity to the Colorado Plateau.

Due to greater paleorelief, the stratigraphic record of sequential eruptions is less complete in the northeastern San Juan Mountains than in central parts of this volcanic region. Many volcanic deposits in the northeast sector accumulated in deep valleys, which were incompletely filled and then re-excavated by erosion between successive eruptions. The regional ignimbrites, rather than forming a stratified plateau, can be preserved in inverted topographic order, with earlier tuff sheets capping ridges and younger units exposed at lower levels within paleovalleys. In many places, welded tuffs are exposed as isolated scabs, unconformably against slopes of paleovalleys, without stratigraphic continuity between sequential deposits. 
Frequent miscorrelations of ignimbrite units in previously mapped local areas of the northeastern San Juan region have resulted from such complexities, as well as from limited exposures due to forest cover, incomplete knowledge of the regional eruptive sequence, and inadequate recognition of petrographic distinctions among tuff sheets.

Erosional postvolcanic dissection to depths of as much as $1.5 \mathrm{~km}$ in the San Juan region has exposed diverse features of intracaldera ignimbrite and associated caldera-fill deposits that accumulated to multikilometer thickness within concurrently subsiding caldera structures. The calderas display a variety of postcollapse structures, and caldera-forming events produced complex fault geometries that localized late mineralization, especially at Platoro, Creede, and several western San Juan calderas. Most of the San Juan calderas have been severely eroded, exposing internal deep structures of the caldera, and their identification has been dependent on detailed geologic mapping. In the map area, however, the near-pristine Oligocene morphology of the Cochetopa Park caldera has been exceptionally preserved because of rapid infilling by moat sediments, which were preferentially eroded only during the past few million years. Cochetopa Park is also marked by a large negative gravity anomaly (Plouff and Pakiser, 1972; Drenth and Keller, 2004). As a result, this feature has long been recognized as a major caldera (Steven and Lipman, 1976), even though its association with a specific ignimbrite eruption has remained obscure (Lipman, 2000, p. 37). In contrast, the newly recognized North Pass caldera is largely concealed beneath erosion-resistant calderafilling lavas that form an inverted present-day topography, in the Cochetopa Hills along the present-day Continental Divide.

\section{Early Northern Volcanism Along the Sawatch Trend}

Volcanism in northern parts of the SRMVF began at least as early as $38 \mathrm{Ma}$, as recorded by andesitic lavas and breccias in the Thirtynine Mile volcanic area (McIntosh and Chapin, 2004). Caldera sources for all early-erupted (37-33 Ma) large ignimbrites of the SRMVF (table 1) form a north-northwesterly alignment along the crest of the Sawatch Range (fig. 1). The first major regional ignimbrite was the far-traveled Wall Mountain Tuff (Chapin and Lowell, 1979) erupted at 36.9 Ma (McIntosh and Chapin, 2004) from vents above the 25- x 35-km Mount Princeton batholith (Johnson and others, 1989; Lipman, 2007), the largest Tertiary intrusion in the Rocky Mountains (fig. 1, table 1). Distal Wall Mountain Tuff spread eastward more than $100 \mathrm{~km}$ from its source, onto the High Plains between Denver and Colorado Springs (Chapin and Lowell, 1979). This ignimbrite (Twm) has now been recognized as local valley-fill deposits in the west-central map area (photo 1, CD-ROM), 80-90 km southwest of Mount Princeton, which represent the only known localities west of the Sawatch Range.

North of the Mount Princeton batholith is the Grizzly Peak caldera and associated tuff (Fridrich and others, 1998), active at 34.3 Ma (McIntosh and Chapin, 2004). Nested within the south margin of the Princeton batholith is the slightly younger Mount Aetna caldera (fig. 1), source of the 34.1-Ma Badger Creek Tuff
(Epis and Chapin, 1974; Johnson and others, 1989) and associated intrusions (34.1-29.6 Ma; McIntosh and Chapin, 2004).

Small remnants of Badger Creek Tuff ( $\mathrm{Tbc}$ ) are preserved at the northeast corner of the map area.

Just east of the map area, small exposures of megabreccia, mapped by Olson (1983) in upper Marshall Creek at the northeast margin of the San Juan Mountains, were interpreted by Gregory and McIntosh (1996) as collapse breccia within an inferred Marshall caldera. Recent studies east of the Continental Divide have located a previously unrecognized caldera margin, at a striking topographic feature known as "The Gate" near the boundary between the Bonanza and Mount Ouray quadrangles (fig. 4); thick welded tuff of intracaldera type banks against Precambrian wall rocks (P. Lipman, unpub. data, 2008). This caldera margin continues across Marshall Pass and connects with the megabreccia in Marshall Creek, but much of the Marshall caldera is concealed beneath younger lava flows and truncated to the southeast by the Bonanza caldera. The Marshall caldera appears to have been the source of the 33.9-Ma Thorn Ranch Tuff, a widespread ignimbrite in the Thirtynine Mile volcanic remnant to the northeast (Epis and Chapin, 1974; McIntosh and Chapin, 2004). Surprisingly, no preserved outflow remnants of Thorn Ranch Tuff or other ignimbrite sheet that could have erupted from this caldera have been found farther west or south in the San Juan Mountains.

The more completely preserved Bonanza center, including the caldera source of the Bonanza Tuff at 33.2 Ma (photo 2, CD-ROM), also lies within the San Juan Mountains (fig. 4) but is equally appropriately considered the youngest and southernmost caldera along the Sawatch trend (Varga and Smith, 1984; McIntosh and Chapin, 2004). The Bonanza and The Marshall calderas mark the beginning of caldera progression to the southwest into the core of the San Juan volcanic region. The Bonanza center contains voluminous andesite erupted before and after ignimbrite eruptions, as well as postcaldera intrusions.

\section{San Juan Volcanic Region}

The San Juan Mountains are the largest erosional remnant of the SRMVF (fig. 1). Preserved rocks of the San Juan region occupy an area of more than $25,000 \mathrm{~km}^{2}$ and have a volume of about $40,000 \mathrm{~km}^{3}$. They cover a varied basement of Precambrian to early Tertiary rocks along the uplifted and eroded west margin of the Late Cretaceous to early Tertiary (Laramide) uplifts of the Southern Rocky Mountains and adjoining portions of the San Juan Basin on the eastern Colorado Plateau (fig. 1). The San Juan region is one of many loci of Tertiary volcanic activity - including the Sierra Madre Occidental, Trans-Pecos, Mogollon-Datil, Absaroka, Challis, and Lowland Creek fields - that developed along the eastern Cordilleran margin of the North American plate, probably in a complex response to changing subduction geometry along its west margin.

As mid-Tertiary volcanism migrated southward from the Sawatch Range trend, widely scattered intermediate-composition centers (dominantly andesite, lesser dacite, minor rhyolite) erupted lava flows and flanking volcaniclastic breccias in the 
San Juan region starting at 35-34 Ma (Lipman and others, 1970; Lipman and McIntosh, 2008). The intermediate-composition assemblage, which constitutes about two-thirds the volume of the preserved volcanic assemblage, is widely overlain by numerous large-volume compositionally diverse ignimbrite eruptions and associated caldera collapses (Steven and Lipman, 1976). After about $26 \mathrm{Ma}$, volcanism shifted to a bimodal assemblage dominated by trachybasalt and silicic rhyolite, concurrent with the inception of regional extension during establishment of the Rio Grande rift.

Large ignimbrite eruptions began in the northeast San Juan Mountains with eruption of the newly recognized Saguache Creek Tuff (Tsc) from the North Pass caldera at 32.2 Ma (Lipman and McIntosh, 2008). Ignimbrite eruptions gradually became widespread in the southeast San Juan region at about 29.4 Ma (Platoro caldera complex), followed shortly by eruptions mainly of crystal-poor rhyolite from western San Juan calderas (Steven and Lipman, 1976; Bove and others, 2001). Ignimbrite activity progressively focused in the central San Juan Mountains, leading to eruption of the enormous Fish Canyon Tuff $\left(5,000 \mathrm{~km}^{3}\right.$ of monotonously uniform crystal-rich dacite) and collapse of the $35 \times 75 \mathrm{~km}$ La Garita caldera at $28.0 \mathrm{Ma}$ (Lipman, 2000, 2006; Bachmann and others, 2002). In the central San Juans, seven major eruptions of compositionally diverse ignimbrite, with volumes of $100-1,000 \mathrm{~km}^{3}$, erupted during a 1.1-m.y. interval from calderas nested within the enormous La Garita caldera (fig. 2). At each caldera, initial post-ignimbrite volcanism consisted of intermediate-composition to silicic lavas and breccias that variably filled the caldera depressions, some to overflowing.

The eruptive and subsidence history of the most northerly of the central San Juan systems, the San Luis complex from which three regional ignimbrite sheets were erupted in rapid succession at 26.9 Ma (Lipman and McIntosh, 2008), is closely intertwined with development of the Cochetopa Park caldera (figs. 2, 4). In particular, the final large eruption, which produced the Nelson Mountain Tuff, appears to have triggered subsidence both at the eruption site in the San Luis complex and at Cochetopa Park, as discussed below.

\section{Early Lavas and Intrusions: Saguache- Cochetopa Region (35-32 Ma)}

As elsewhere in the San Juan region, ignimbrite sheets and other rocks associated with calderas in the SaguacheCochetopa region overlie thick lava sequences that erupted from large central volcanoes (fig. 4). In comparison with the early-intermediate assemblage farther south and west in the San Juan Mountains, (1) the northeastern area contains higher proportions of proximal lavas and breccias relative to distal laharic conglomerates and other volcaniclastic rocks (photo 3A, CD-ROM ), and (2) dacite and rhyolite are more voluminous components of the dominantly andesitic lava assemblage.

These early flows are broadly correlative with the Conejos Formation elsewhere in the San Juan region (Lipman and others, 1970; Dungan and others, 1989), but several earlyerupted tuff sheets are interstratified with lavas of ages that predate all ignimbrite units from farther south and west in the San Juan Mountains. These interstratified tuff sheets, including several from caldera centers along the Sawatch trend, and datable sanidine phenocrysts in some silicic lavas help define the eruptive history of early lavas in more detail than has been possible elsewhere in the region. The lavas that are interstratified with the early tuff sheets, as well as andesitic and dacitic lavas that ponded within ignimbrite calderas throughout the San Juan region and are described as late phases of individual caldera cycles, are compositionally indistinguishable from earliererupted lavas of the Conejos assemblage and are concurrently interpreted to constitute eruptive continuity in the dominantly intermediate-composition regional volcanic field (SRMVF).

In the northeastern San Juan region, lavas are locally exposed over a vertical range of more than 1,000 $\mathrm{m}$ from along Saguache Creek to the Continental Divide, although thicknesses decrease northward toward the Gunnison valley. Total thickness and volume is far greater for the early lavas than for interstratified and overlying ignimbrite sheets. At least eight eruptive centers for Conejos lavas lie within the area of figure 4, but several of the best preserved are east of the detailed geologic map. These centers probably include the earliest eruptions in the San Juan region, with activity becoming younger to the west and south:

(1) A large composite stratocone or cluster of early Conejos-age volcanoes, within which the Bonanza caldera is centered, is overlain by the 33.2-Ma Bonanza Tuff on its flanks and must be among the oldest of these centers, although detailed mapping and ${ }^{40} \mathrm{Ar} /{ }^{39} \mathrm{Ar}$ dating are incomplete for much of the area. These lavas, locally designated the Rawley Andesite (Burbank, 1932; Varga and Smith, 1984), include dacite and rhyolite flows low in the section, resting directly on Precambrian basement. An upper lava sequence of the Bonanza center, including caldera-filling flows, is also dominantly andesitic; its age is bracketed as 33-32 Ma by the underlying Bonanza Tuff and overlying 32.2-Ma Saguache Creek Tuff.

(2) South of the Saguache valley, a thick lava pile marks the north flanks of another large central volcano of Conejos age, also east of the map area but separate from the Bonanza center. The Bonanza Tuff wedges out within these southern lavas, above a sequence of dark andesite flows, but below capping lavas of porphyritic dacite on Tracy Mountain (fig. 4, LG). A petrographically unusual dacite flow high in this assemblage, containing sanidine phenocrysts as large as $2 \mathrm{~cm}$ across, yielded $\mathrm{a}^{40} \mathrm{Ar} /{ }^{39} \mathrm{Ar}$ age of $32.72 \pm 0.09 \mathrm{Ma}$, consistent with its inferred position beneath the Saguache Creek Tuff.

(3) Well-exposed radial dikes and outward-dipping andesitic lavas just east of the North Pass caldera define the core of another eastern volcano centered in the Jacks Creek drainage (fig. 4, LMNE; Bruns and others, 1971) that is about the same age as Rawley Andesite at Bonanza. The Jacks Creek volcano predates eruption of the Bonanza Tuff, which laps out against its eroded flanks and onto dikes in its core; in-progress ${ }^{40} \mathrm{Ar} /{ }^{39} \mathrm{Ar}$ determinations for lavas and intrusions of this center are mostly in the range 34-35 Ma (W. McIntosh and P. Lipman, unpub. 
data, 2007-08), among the oldest dated rocks from the San Juan region. Andesitic to rhyolitic lavas that are capped by scattered small erosional remnants of Bonanza Tuff as far east as the Continental Divide just north of the North Pass caldera (fig. 4, NP) also must be roughly correlative to the Rawley Andesite.

(4) Farther northwest of the Continental Divide, the large (3.5 x $9 \mathrm{~km}$ ) Needle Creek intrusion (fig. 4, WB) is exposed at near roof level and is texturally variable, ranging from nearly aphanitic andesite to fine-grained granodiorite. This body in places appears to have grown as coalesced dikes; elsewhere, subhorizontal upper contacts suggest growth as a laccolithic complex. Despite its northeasterly trend, aligned with ignimbrite-related structures farther southwest, phases of this intrusion have yielded hornblende ${ }^{40} \mathrm{Ar} /{ }^{39} \mathrm{Ar}$ ages of $34.3-34.4 \mathrm{Ma}$ (table 2), suggesting that it constitutes the early-Conejos-age source of the large surrounding sequence of proximal andesitic lavas. This intrusion and associated dikes (photo 3B, CD-ROM) likely mark the core of another large andesitic stratovolcano. A nearby dacite flow, low in the lava assemblage, has sanidine ${ }^{40} \mathrm{Ar} /{ }^{39} \mathrm{Ar}$ ages of $34.0-34.1 \mathrm{Ma}$. The Needle Creek intrusion is also spatially associated with voluminous younger silicic lava flows within the upper Conejos Formation (rhyolite of Barret Creek; 29.6-30.1 Ma; fig. 4), an unusual assemblage for the precaldera assemblage. Unroofed southern parts of the Needle Creek intrusion are overlain by unaltered Fish Canyon Tuff, indicating that deep erosion occurred prior to eruption of this ignimbrite at $28 \mathrm{Ma}$.

(5) The near-horizontal roof zone of another large highlevel intrusion (at least $3.5 \mathrm{~km}$ across), composed of variably altered porphyritic dacite and fine-grained granodiorite, is exposed along lower canyon slopes in upper Long Branch (SM). This body, with an isotopic age of about $33 \mathrm{Ma}$ (table 2), was erosionally unroofed (or nearly so) prior to eruption of the Bonanza Tuff at 33.2 Ma and appears likely to constitute the late-intruded core of another early volcanic edifice, east of the Needle Creek intrusion.

(6) The core of yet another large central volcano that consists dominantly of andesite is marked by an elliptical pluton of porphyritic hornblende andesite, the Sawtooth intrusion (1 x 1.5 $\mathrm{km}$ across), and associated smaller plugs and dikes farther south that intrude Conejos lavas and breccias on the northwest inner slope of the Cochetopa Park caldera (photo 3C, CD-ROM). A cluster of northwest-trending dikes of compositionally similar hornblende andesite cut Conejos rocks exposed on the floor of the caldera across the valley of Cochetopa Creek to the east (RD). Both groups of hornblende-bearing intrusions appear to be central parts of a large stratocone that is flanked to the northwest and northeast by the lava piles on Sawtooth Mountain and Razor Creek Dome (fig. 4, ST, RD). The age of this volcano is convincingly bracketed only by the underlying Wall Mountain Tuff (Twm, 36.9 Ma) and overlying Sapinero Mesa Tuff (Tws, $28.3 \mathrm{Ma}$ ). The volcano may be largely or entirely younger than the Saguache Creek Tuff (Tsc, 32.2 Ma), but field and age relations remain ambiguous. The capping flow on Sawtooth Mountain yielded a hornblende age of $32.00 \pm 0.09 \mathrm{Ma}$, but a dike cutting the Conejos lava sequence low on the south flank of Razor Creek Dome has a hornblende ${ }^{40} \mathrm{Ar} /{ }^{39} \mathrm{Ar}$ age of
34.61 \pm 0.16 Ma. Erosional remnants of Saguache Creek Tuff rest directly on prevolcanic rocks around the northwest flank of Sawtooth Mountain, and poor exposures of this tuff on heavily timbered north slopes appear to be overlain by andesite lava flows on both sides of upper East Beaver Creek (SH). In this case, the entire Sawtooth Mountain lava sequence would have been emplaced during the interval 32.2-32.0 Ma. Alternatively (and seemingly less likely), this edifice might predate and have been severely eroded prior to eruption of the Saguache Creek Tuff, which then banked unconformably against its northwest flank.

(7) A highly altered Conejos-age intrusion of porphyritic biotite-plagioclase dacite that forms an erosional basin within a structural ridge between two northeast-trending grabens, exposed in Blue Creek along the southwest margin of Cochetopa Park caldera (CS), is a probable center for thick andesitic lavas that underlie the 32.2-Ma Saguache Creek Tuff along the Continental Divide and separate Cochetopa Park from La Garita caldera to the south (fig. 4). These altered rocks are surrounded and covered by unaltered Fish Canyon and Carpenter Ridge Tuffs. West of the map area, along the north margin of La Garita caldera, some dacite and rhyolite lavas are as young as 29.7 Ma (Lipman, 2006), but direct stratigraphic relations to Saguache Creek or Bonanza Tuffs are absent.

(8) A dike-like plug of nearly aphanitic basalt at point Benny (NP; triangulation station herein named point Benny), about $5 \mathrm{~km}$ east of the North Pass caldera, is an exceptionally mafic late Conejos intrusion (Tbpi) that forms the vent for a basaltic cone and an associated basaltic flow (photo 4, CD-ROM). A mean groundmass ${ }^{40} \mathrm{Ar} /{ }^{39} \mathrm{Ar}$ age of $30.2 \pm 0.1 \mathrm{Ma}$ and onlap by Fish Canyon Tuff show that this vent and flow are part of the Conejos Formation (upper units), rather than related to compositionally similar Miocene basalt (Hinsdale Formation).

\section{Saguache Creek Tuff and North Pass Caldera Cycle (32.2 Ma)}

A recurrent problem in studies of San Juan volcanism has been establishing reliable regional correlations for multiple widespread but discontinuously exposed ignimbrite units of similar petrologic characteristics. Among such puzzles has been the inferred extreme northeast extent of the Sapinero Mesa Tuff (Tws), a large-volume ignimbrite erupted from the western San Juan caldera cluster (fig. 10 of Steven and Lipman, 1976). Since the late 1960s, the Sapinero Mesa has been inferred to include densely welded crystal-poor rhyolite ignimbrite that crops out widely in the valley of Saguache Creek, as much as $90 \mathrm{~km}$ from the western San Juan caldera cluster (Bruns and others, 1971; Simon and Wendlandt, 1999). This distribution of the Sapinero Mesa is highly asymmetric to the source caldera, and the ignimbrite in the Saguache valley is atypically thick and densely welded, compared to similarly distal portions of this unit elsewhere. 
Such concerns, along with recognition of problems with published interpretations of the Cochetopa Park caldera (Lipman, 2000, p. 37), led to tentative inference that the rhyolitic ignimbrite in Saguache Creek might be a separate ignimbrite erupted from this more proximal caldera. Initial results from restudy of the Cochetopa area demonstrated (1) that the ignimbrite in Saguache Creek was indeed a different ignimbrite, now named the Saguache Creek Tuff (Lipman and McIntosh, 2008) and distinguishable from the Sapinero Mesa Tuff by hand-lens petrography (absence of biotite), more alkalic rock and mineral compositions, and isotopic ages (Lipman and Calvert, 2003), but (2) that at least the last major subsidence at Cochetopa Park was too young to be associated with eruption of this ignimbrite (postdating emplacement of the Fish Canyon Tuff, which overlies the welded ignimbrite in Saguache Creek). Detailed mapping in Cochetopa Park and farther east has now documented that the previously unrecognized North Pass caldera (figs. 4, 5) was the source of the Saguache Creek Tuff.

As interpreted here, the North Pass caldera is a filled depression, about $15 \mathrm{~km}$ across, that straddles the present-day Continental Divide in the Cochetopa Hills (fig. 4, NP). This caldera cycle includes precursor tuffs and lavas of probable small volume and limited areal extent, the regional calderarelated Saguache Creek Tuff, a thick sequence of lava flows and volcaniclastic rocks that filled the caldera, and the lateerupted Luders Creek Tuff that may have erupted from within central parts of this caldera that are now covered by younger ignimbrites from the San Juan central caldera complex. Small preserved areas of younger andesite flows ( $\sim 30 \mathrm{Ma})$ may be late parts of the North Pass cycle or just continued background flux of intermediate-composition magmatism. An alternative proposed caldera source for the Saguache Creek Tuff, $30 \mathrm{~km}$ farther northeast along the Continental Divide (Turner and others, 2003), instead appears to mark the core of a large andesitic stratovolcano that predated the 33-Ma Bonanza Tuff; no mapped geologic features support the presence of a major ignimbrite caldera in this area.

In contrast to Cochetopa Park, no well-defined gravity low is associated with the North Pass caldera, perhaps due to the presence of thick dense caldera-filling lavas and (or) presence of relatively mafic subvolcanic intrusions. Similar lack of strong gravity expression characterizes several other calderas along the east side of the San Juan Mountains, including Bonanza and Platoro calderas (Plouff and Pakiser, 1972).

High-resolution ${ }^{40} \mathrm{Ar} /{ }^{39} \mathrm{Ar}$ dating (Lipman and McIntosh, 2008) shows that the entire North Pass caldera cycle, including a possible precursor ignimbrite of small volume, the culminating eruption of the Saguache Creek Tuff, post-caldera lavas, and late eruption of the Luders Creek Tuff, developed within a brief interval at 32.5-32.2 Ma (table 2). For the subsequent 4 m.y., volcanism was relatively quiescent within and adjacent to the caldera area, limited to a few small andesite lava flows, and erosion was dominant. In many places, the 28-Ma Fish Canyon Tuff rests directly on Saguache Creek Tuff or occupies paleovalleys eroded below depositional levels of the Saguache Creek.

\section{Precursor(?) Lavas (32.2 Ma) and Tuff of Spanish Creek (32.5 Ma)}

Three small areas of distinctive rhyolitic ignimbrite, the tuff of Spanish Creek, are exposed within short distances east and north of the North Pass caldera; this unit has yielded ages only a few hundred thousand years older than the main ignimbrite eruption from this caldera. These crystal- and quartz-rich tuffs (sanidine ${ }^{40} \mathrm{Ar} /{ }^{39} \mathrm{Ar}$ ages of $32.5 \mathrm{Ma}$ ) overlie the assemblage of early lavas, are younger than the Bonanza Tuff, and seem plausibly interpreted as initial eruptions broadly associated with the North Pass cycle. Some of these tuffs were initially considered potential candidates for distal deposits from Sawatch Range centers, but their younger ages preclude such correlations. Breccia clasts from the tuff of Spanish Creek are present along the northwest margin of the North Pass caldera, which helps constrain the timing of caldera collapse.

A large rhyolite lava dome centered between Archuleta and Los Creeks (CP) and an east-west-trending stubby dike-like body of altered dacite porphyry just west of Cochetopa Pass at the southwest margin of the North Pass caldera (NP) have both yielded ${ }^{40} \mathrm{Ar} /{ }^{39} \mathrm{Ar}$ ages of about 32.2 Ma (table 3, CD-ROM). Although these ages are analytically indistinguishable from the time of caldera formation, both units appear to be truncated unconformably by the caldera topographic wall and caldera-fill lavas, indicating late-precaldera emplacement.

\section{Saguache Creek Tuff (32.25 Ma)}

The Saguache Creek Tuff (Tsc), as named by Lipman and McIntosh (2008), is a distinctively alkalic crystal-poor rhyolitic ignimbrite $\left(72.3-75.4 \% \mathrm{SiO}_{2}\right)$ that is widely preserved in the Saguache basin (photo 5, CD-ROM), as well as in scattered erosional remnants farther northwest. It is especially well exposed along Saguache Creek along the east edge of the map area, where it overlies the Conejos Formation and is overlain by Fish Canyon Tuff. Its newly mapped distribution is roughly symmetric around the North Pass caldera, if allowance is made for more Oligocene erosion in the northwest sector and widespread cover by younger rocks to the southwest. On published U.S. Geological Survey (USGS) geologic quadrangle maps, many of the scattered northwestern outcrop areas, which are now reliably identified as Saguache Creek Tuff by composition and isotopic age, were previously miscorrelated with diverse regional ignimbrites from the central caldera cluster.

The maximum exposed thickness of the tuff, 50-75 m, occurs along the axial Saguache paleovalleys. Although widely eroded elsewhere, the areal extent and thickness of preserved densely welded exposures yield an estimated $250 \mathrm{~km}^{3}$ of magmatic volume for the outflow sheet. If this tuff is thickly ponded within its source caldera, as is typical of other large San Juan ignimbrites, its total volume (neglecting downwind ash) could be $\sim 500 \mathrm{~km}^{3}$. Where thickness of the Saguache Creek Tuff exceeds a few tens of meters, the interior of the sheet is densely welded (photos 5A,B, CD-ROM), commonly with gray pumice lenses (to $10 \mathrm{~cm}$ ) in a purple-brown matrix. A central zone of spherical to lenticular gas cavities $5-10 \mathrm{~cm}$ 
in longest dimension is common where densely welded (photo 5D, CD-ROM), similar to other crystal-poor ignimbrites in the region. In places, the Saguache Creek is densely welded nearly to its base, but the lower 5-10 m commonly is nonwelded white to tan tuff. Where not eroded, 10-20 m of upper nonwelded vapor-phase to glassy tuff is widely present, though typically largely covered by talus and slope wash from overlying units (photo 5B, CD-ROM).

The Saguache Creek Tuff widely rests on early (35-33 Ma) andesitic lavas, but as much as 10-20 m of water- and windreworked tuffaceous sediments are present locally between andesite and overlying ignimbrite along the axial Saguache paleovalley (photo 5C, CD-ROM). In the paleovalley, this ignimbrite is widely overlain conformably by Fish Canyon Tuff that is $4 \mathrm{~m}$.y. younger, with only thin intervening tuffaceous sediments. Weakly welded biotitic rhyolitic ignimbrite that appears to be distal Sapinero Mesa Tuff and discontinuous 30-Ma andesite lavas are also present locally between the Saguache Creek and Fish Canyon Tuffs along Saguache Creek. To the northeast, the Saguache Creek laps out against Bonanza Tuff and overlying andesite on the flank of the Bonanza caldera center. In contrast to the conformable sequence in the Saguache paleovalley, the discontinuous erosional remnants of Saguache Creek Tuff typically cap ridges and mesas to the northwest (HG, IR), while Fish Canyon Tuff was deposited topographically lower, within re-excavated paleovalleys. In places, paleolandside and talus of Saguache Creek clasts are overlain by Fish Canyon Tuff along walls of such paleovalleys, documenting times of valley erosion.

No in-place Saguache Creek Tuff or older rocks are exposed within central parts of the North Pass caldera, but an exceptionally thick $(>200 \mathrm{~m}$ ) elliptical exposure of tuff interpreted as the wedge edge of an intracaldera accumulation is banked against the western topographic margin (NP). This high ridge of Saguache Creek Tuff dips $15^{\circ}-25^{\circ}$ into the caldera and is overlain by caldera-fill units. In contrast, proximal outflow ignimbrite sheets are typically absent or thin on high-standing caldera rims elsewhere in the San Juan region. Only small scattered patches of outflow Saguache Creek Tuff, seemingly remnants of discontinuous deposits against high-standing irregular paleotopography, bank against older rocks of the Conejos Formation at varied topographic levels adjacent to the west caldera margin. Along the east margin of the North Pass caldera (TM), small remnants of outflow Saguache Creek Tuff are truncated abruptly and are covered by the lava sequence that is interpreted to have filled the caldera (fig. 8, sheet 2). All dated caldera-filling dacite and rhyolite lavas have yielded ages similar to, or younger than, the Saguache Creek Tuff (table 2).

Major phenocrysts (3-10\% total) of the Saguache Creek Tuff are sodic low-barium sanidine $\left(\mathrm{Or}_{51} \mathrm{Ab}_{46} \mathrm{An}_{2.7} \mathrm{Cn}_{0.4}\right)$ and plagioclase; biotite is absent or extremely sparse. Otherwise similar-appearing crystal-poor rhyolitic ignimbrites of the San Juan region, such as the Sapinero Mesa and Carpenter Ridge Tuffs, contain biotite phenocrysts, have more potassic sanidine compositions (typically $\mathrm{Or}_{60-65}$ ), and have less alkalic majorand trace-element compositions (lower $\mathrm{Na}, \mathrm{Zr}$, and light $\mathrm{REE}$ such as La and Ce; higher Sr and Ba: table 4). Despite broad similarities to other crystal-poor rhyolite tuffs of the area, these details show that the Saguache Creek Tuff is compositionally unique in the San Juan region. The eruption age is tightly constrained at $32.25 \pm 0.05 \mathrm{Ma}$, from the weighted mean of six new laser-fusion sanidine ${ }^{40} \mathrm{Ar} /{ }^{39} \mathrm{Ar}$ determinations from geographically diverse sites (table 2). The Saguache Creek Tuff has a reversed paleomagnetic direction, based on sample sites along Saguache Creek and west of the North Pass caldera (Lipman and McIntosh, 2008, table 3).

\section{Formation of the North Pass Caldera}

Eruption of the Saguache Creek Tuff from a nonresurgent caldera in the North Pass area, which was then filled by younger lavas, is documented by the distribution of this ignimbrite, abrupt truncations of regional units, local hydrothermal alteration along caldera margins, and the ages and compositions of caldera-filling rocks. The regional distribution of the Saguache Creek Tuff is broadly symmetric around flanks of the caldera, as shown by erosional remnants preserved as much as $15 \mathrm{~km}$ east, $10 \mathrm{~km}$ south, and $30 \mathrm{~km}$ northwest (fig. 4). Absence of distal exposures to the southwest is due to widespread cover by young volcanic units of the central caldera cluster. Small isolated paleohills of Precambrian granitic rocks exposed around the margins of the caldera-filling assemblage, but nowhere within the depression, also help define limits of the North Pass caldera. Rocks filling the North Pass caldera, as well as the entire volcanic sequence east of the Continental Divide, dip gently eastward $\left(5^{\circ}-10^{\circ}\right)$, probably in response to regional tilting along the entire west flank of the San Luis Valley segment of the Rio Grande rift zone (fig. 1). As a result, deeper older caldera-fill units crop out along the west margin of the North Pass caldera; younger deposits are preserved to the east.

Caldera subsidence at North Pass postdates emplacement of the Saguache Creek Tuff, which is truncated along exposed sectors of both the east and west caldera margins, and predates the Fish Canyon Tuff. The caldera-margin unconformity that defines surface expression of the North Pass caldera, although unimpressive around much of its perimeter because precaldera Conejos (Rawley) andesite and dacite are lithologically similar to the caldera-filling lavas and volcaniclastic rocks, is well exposed on the east side just east of Sheep Creek, a tributary of Saguache Creek (TM). Here bleached and otherwise hydrothermally altered Conejos lavas and overlying Saguache Creek Tuff are abruptly truncated along a steep westward-facing contact, against which are banked thick ponded flows of andesite, overlain by anomalously thick and densely welded Fish Canyon Tuff (fig. 8; photo 6, CD-ROM).

A similar truncation of regional units, including Saguache Creek Tuff, is associated with local hydrothermal alteration along the west caldera margin, although relations are less clear on this flank because of fault complexities and more limited exposures. On this side of the caldera, in roadcuts along Colorado Hwy 114 (northwest NP), highly disrupted Conejos rocks and small masses of welded Bonanza Tuff and tuff of Spanish Creek are intermixed with nonwelded Saguache Creek Tuff on scales too complex to depict even on a detailed geologic 
map (photo 7, CD-ROM ); the assemblage is interpreted as caldera-margin megabreccia. At the mouth of Pine Creek and in Hwy 114 roadcuts just to the north, blocks of tuff of Spanish Creek, along with fragments of Bonanza Tuff, probably represent more finely comminuted caldera-collapse breccia. The North Pass caldera-fill assemblage is also notably less altered than adjacent Conejos lavas and volcaniclastic rocks that define the east caldera margin east of lower Sheep Creek and the west margin along Lujan Creek (NP).

The caldera was filled with thick dacite lava flows and local rhyolite domes (volcanics of Cochetopa Hills) that have isotopic ages similar to the 32-Ma Saguache Creek Tuff (photo 8, CD-ROM ). Otherwise lithologically similar precaldera lavas of the Conejos Formation and Rawley Andesite are largely or entirely older (33-35 Ma) in areas adjacent to the North Pass caldera. In addition, laharic volcaniclastic rocks within the caldera area, which mainly contain clasts of intermediate-composition lavas, locally contain sparse fragments of Saguache Creek Tuff, which requires that these deposits are also younger than otherwise similar clastic rocks of the Conejos Formation that underlie this ignimbrite adjacent to the caldera.

The caldera-filling lavas are resistant to erosion and support a segment of the present-day Continental Divide; as a result, the caldera remains largely buried. The thickness of exposed caldera fill exceeds $500 \mathrm{~m}$, but erosion has been insufficient to expose underlying rocks. As a result, neither the total subsidence nor the likely presence of thick intracaldera Saguache Creek Tuff can be evaluated from present-day exposures.

\section{Caldera-filling Lavas (Volcanics of Cochetopa Hills, $32.2 \mathrm{Ma}$ )}

The volcanics of Cochetopa Hills are a diverse assemblage of lava flows and volcaniclastic deposits that accumulated rapidly within the North Pass caldera after subsidence during eruption of the Saguache Creek Tuff. The bulk of the lavas at exposed levels are flows of porphyritic dacite that overlie diverse volcaniclastic rocks and scattered lava domes of crystalpoor rhyolite that have compositions similar to the Saguache Creek Tuff (table 4).

Massive flows of gray to tan crystal-rich dacite (Tnpd, dacite of East Pass Creek) are the dominant exposed fill in the caldera. The thickest and most widespread accumulations are north of North Pass (photo 8, CD-ROM ), where multiple flows are locally mappable, based on zones of basal vitrophyre and upper carapace breccia. Individual flows are as thick as 200 $\mathrm{m}$; total exposed thickness is greater than $500 \mathrm{~m}$. These flows are petrographically fairly uniform, containing 20-30 percent phenocrysts of blocky plagioclase (to $1 \mathrm{~cm}$ ), biotite, and clinopyroxene \pm hornblende; sanidine is absent. Compositionally, this unit is typical dacite of the region $\left(\mathrm{SiO}_{2}, 61.4-66.0 \%\right)$. Biotite plateau ${ }^{40} \mathrm{Ar} /{ }^{39} \mathrm{Ar}$ ages for three samples from the main area of exposure are 32.07-32.31 Ma, consistent with eruption soon after the Saguache Creek Tuff at 32.25 $\pm 0.05 \mathrm{Ma}$ (table 2). A small outlier of similar dacite that is banked unconformably against a slope along the inferred south margin of the North
Pass caldera (GC) yielded slightly older ages of $32.82 \pm 0.08 \mathrm{Ma}$ (bio) and $32.75 \pm 0.15 \mathrm{Ma}(\mathrm{hbl})$; interpretation of this flow as part of the caldera fill remains ambiguous.

Scattered lava domes of phenocryst-poor gray to light-tan rhyolite (Tnpr, rhyolite of Taylor Canyon), exposed locally beneath the dacite of East Pass Creek, are also interpreted as fill of the North Pass caldera. Flow layering, glassy carapace breccia, and ramp structures near upper surfaces are typical (photo 8A, CD-ROM). Analyses from several flows, exposed along the west caldera wall and farther to the east $\left(74-76 \% \mathrm{SiO}_{2} ; 1-5 \%\right.$ sanidine, plagioclase), are similar to the Saguache Creek Tuff in lacking biotite phenocrysts and containing elevated levels of incompatible trace elements. One flow yielded a sanidine age of $32.15 \pm 0.10 \mathrm{Ma}$. Exposed thickness of the rhyolite is as much as $150 \mathrm{~m}$.

At lowest exposed levels, laharic conglomerate, sandstone, and water-reworked tuff (Tsa) are interlayered with and underlie the lava flows within the North Pass caldera. Most widespread are crudely bedded laharic breccias, along with better bedded conglomerate, that mainly contain clasts of dark-gray andesite and dacite in weakly indurated lighter-gray sandy matrix. Outcrops are rare; the unit typically forms loose cobbles on subdued slopes. These rocks, likely recording rapid postcollapse erosion of Conejos (Rawley) lavas along the inner caldera slopes, closely resemble volcaniclastic sediments of the older Conejos Formation. A key to identification as a younger volcaniclastic deposit is the presence of rare clasts of Saguache Creek Tuff.

Thin deposits of white to light-tan bedded rhyolitic tuff (Tst), deposited in shallow-lake or low-energy-stream environments, are preserved discontinuously along the west caldera margin (NP), where they interfinger with and overlie older caldera-fill units. These deposits resemble younger tuffaceous sedimentary fill of the Cochetopa Park caldera to the west, but their higher topographic level and location along margins of the North Pass caldera suggest that they are late sedimentation in this caldera, probably in conjunction with eruption of rhyolitic lava flows or the Luders Creek Tuff. Obscure gully exposures along the west side of the Continental Divide demonstrate that at least some lake beds underlie the Luders Creek Tuff. The preserved thickness is less than $30 \mathrm{~m}$, consistent with rapid filling of the North Pass caldera by the volcanics of Cochetopa Hills without any persistent lake or other sediment-filled basin.

\section{Luders Creek Tuff (32.17 Ma)}

A distinctive compositionally zoned ignimbrite, the Luders Creek Tuff (named by Lipman and McIntosh, 2008), crops out on the Continental Divide along the west side of the North Pass caldera. The Luders Creek Tuff grades from weakly welded tan rhyolite (TIr: $72-73 \% \mathrm{SiO}_{2} ; 5-10 \%$ plagioclase and sanidine phenocrysts, sparse biotite) upward into densely welded dark dacite (Tld: $66-68 \% \mathrm{SiO}_{2} ; 20-30 \%$ plagioclase, sanidine, biotite, sparse clinopyroxene). It appears to be a late eruptive unit of the North Pass cycle, based on its location and age.

Four sanidine ${ }^{40} \mathrm{Ar} /{ }^{39} \mathrm{Ar}$ ages for the Luders Creek Tuff (weighted mean: $32.17 \pm 0.04 \mathrm{Ma}$ ) are only slightly younger 
than the Saguache Creek Tuff $(32.25 \pm 0.02 \mathrm{Ma})$, providing a tight age bracket for the entire sequence of lavas and volcaniclastic deposits within the North Pass caldera (table 2; table 3, CD-ROM). Limited preserved distribution of the Luders Creek Tuff suggests probable eruption either from within the North Pass caldera beneath subsequent cover by Fish Canyon and Carpenter Ridge Tuffs or from within adjacent parts of the Cochetopa Park area.

The Luders Creek Tuff is similar in appearance and phenocryst mineralogy to the much younger Nelson Mountain Tuff (26.9 Ma), with which this ignimbrite had been correlated previously (Cochetopa Creek Tuff of Steven and Lipman, 1976, fig. 24). The small remaining areas of in-place Luders Creek Tuff overlie dacite and rhyolite flows (volcanics of Cochetopa Hills), and widespread laharic debris-flow deposits of Buffalo Creek Campground (Tdb), derived from Luders Creek Tuff, overlie the Saguache Creek Tuff and underlie Fish Canyon Tuff across much of the Saguache paleovalley. Some areas of shattered megablocks in the debris-flow deposit, as much as $25 \mathrm{~m}$ across (photo 8C, CD-ROM), are sufficiently large and conspicuous to map separately (Tdbm). The volume of Luders Creek Tuff in the debris-flow deposits exceeds that of preserved in-place exposures. The origin of this large debris flow is unknown, but it is locally interleaved with $~ 30$-Ma andesitic lava flows and, therefore, $\sim 2$ m.y. younger than eruption of the Luders Creek Tuff.

\section{Late Andesite Flows and Associated Rocks (30.0-30.5 Ma)}

Several small areas of andesitic lava and a thin partly welded dacite tuff of similar age, deposited at about $30 \mathrm{Ma}$ along the east side of the North Pass caldera (fig. 9, sheet 2), may be late phases broadly associated with this caldera cycle or, alternatively, local phases of the regional flux of dominantly intermediate-composition lava eruptions (Conejos Formation, upper units).

Oldest are a porphyritic hornblende andesite on hill 9519 (Tahh: $58.1 \% \mathrm{SiO}_{2}$ ) and an overlying aphyric andesite flow (Taha) that bank thickly against the sloping east wall of the caldera at Sheep Creek (figs. 8, 9, southwest TM). The thick hornblende andesite and its inclined columnar-jointed contact against the caldera wall somewhat resemble an intrusive body, but emplacement as a ponded lava flow is indicated by the presence of elliptical vesicles, even within the most massive parts of the unit, and by continuity with subhorizontal eastern parts of the flow that directly overlie Saguache Creek Tuff where the lava overflowed the caldera margin. These flows, which are overlain by the widespread laharic breccia derived from the Luders Creek Tuff, have yielded ${ }^{40} \mathrm{Ar} /{ }^{39} \mathrm{Ar}$ ages of $30.41 \pm 0.79$ Ma (hornblende) and 29.98 $\pm 0.31 \mathrm{Ma}$ (groundmass concentrate), respectively (table 2 ; table $3, \mathrm{CD}$ ROM). The ponding of these lavas, as well as the anomalously thick and densely welded character of overlying Fish Canyon Tuff, demonstrate that the east side of the North Pass caldera remained incompletely filled at the time of their eruption, 2 m.y. after initial caldera collapse.

A thin weakly-welded ignimbrite of crystal-poor dacite (Tbg, tuff of Big Dry Gulch) that has restricted areal extent and small volume along the upper Saguache valley (fig. 9) is a distinctive local marker unit above the Saguache Creek Tuff and the laharic debris-flow deposit with Luders Creek clasts and below andesitic lavas. This gray ignimbrite sheet $\left(67.1 \% \mathrm{SiO}_{2}\right)$ contains 3-5 percent phenocrysts of plagioclase and abundant biotite; sanidine is absent, in contrast to otherwise similarappearing distal portions of crystal-poor regional ignimbrites such as Sapinero Mesa (Tws) or Carpenter Ridge Tuffs (Tcr). Its ${ }^{40} \mathrm{Ar} /{ }^{39} \mathrm{Ar}$ plateau age of $30.47 \pm 0.08 \mathrm{Ma}$ (biotite) links it in time to the late andesite that may represent final stages of the North Pass cycle.

Several well-stratified andesitic lava flows $\left(59 \% \mathrm{SiO}_{2}\right)$ and associated volcaniclastic rocks (Tla, Tlav, andesite of Lone Tree Gulch) separate the tuff of Big Dry Gulch from overlying Fish Canyon Tuffs along the paleo-Saguache valley, on the southeast flank of Trickle Mountain and adjacent areas (photo 9, CD-ROM). Individual flows are 5-10 m thick; maximum total thickness is about $50 \mathrm{~m}$. A groundmass-concentrate ${ }^{40} \mathrm{Ar} /{ }^{39} \mathrm{Ar}$ age of $30.21 \pm 0.17 \mathrm{Ma}$ links this andesite assemblage closely to the andesite flows ponded against the east wall of the North Pass caldera, but the location of these flows well to the east suggests that they represent continued regional flux of intermediate-composition volcanism unrelated to any caldera cycle.

Chaotic breccia and some possibly intact lava flows of dark-gray crystal-poor andesite (Tab, andesite of Big Dry Gulch) form rugged massive outcrops in upper reaches of Big Dry Gulch, a southern tributary of Saguache Creek (LM). Much of this unit appears to have been emplaced by chaotic landslides; some parts may be primary eruptive deposits, perhaps on a proximal flank of the source eruptive edifice. These masses of andesite breccia remained topographic highs at time of eruption of the Fish Canyon Tuff. Age and emplacement relations are unknown relative to the andesite of Lone Tree Gulch; they may represent proximal and more distal portions of the same eruptive sequence.

A flow of silicic alkalic basalt (Tbpf, Tpbv: 52.0\% $\mathrm{SiO}_{2}$ ), erupted from a vent (point Benny, NP) centrally located within the North Pass caldera (fig. 4), also overlies the laharic breccia deposit containing Luders Creek clasts (photo 4, CD-ROM). This finely olivine-phyric basalt contains widely distributed sparse xenocrysts of quartz and feldspar, derived from disaggregated fragments of Precambrian granite. This flow and vent intrusion (Tbpi) are the only known Oligocene basalt in the San Juan region. The weighted mean ${ }^{40} \mathrm{Ar} /{ }^{39} \mathrm{Ar}$ age of $30.22 \pm 0.10 \mathrm{Ma}$ for groundmass-concentrate determinations on five samples, sampled to bracket diverse amounts of Precambrian xenocrystic detritus, is consistent with stratigraphic position beneath Fish Canyon Tuff and also with eruption nearly concurrent with the late andesite ponded against the east wall of the North Pass caldera.

\section{Northern Rhyolite-Dacite Dome Field (29.8 Ma)}

Spatially unrelated to the North Pass caldera system, but broadly concurrent with the late-erupted andesitic lavas just 
described, is a cluster of silicic domes and flows centered on upper Barret Creek, in the north-central part of the map area (fig. 4). These rocks range from nearly aphyric rhyolite (Tbfa: $1-5 \%$ sanidine and plagioclase, sparse biotite; $73-76 \% \mathrm{SiO}_{2}$ ) to crystal-rich silicic dacite and low-Si rhyolite (Tbfc: 15-35\% plagioclase-sanidine-quartz-biotite; $\left.67-74 \% \mathrm{SiO}_{2}\right)$. Individual flows are 50 to $150 \mathrm{~m}$ thick; preserved exposures of the composite flow field cover an area of about $150 \mathrm{~km}^{2}$. The range of laser-fusion ${ }^{40} \mathrm{Ar} /{ }^{39} \mathrm{Ar}$ ages for sanidine phenocrysts from four separate lava flows is 29.63-29.85 Ma; biotite from a fifth flow yielded a slightly older age of $30.08 \pm 0.09 \mathrm{Ma}$ (table 2). These silicic flows lap onto the eroded core of an older andesitic volcano, including a central intrusion (northwest WB) of fine-grained granodiorite (pooled ${ }^{40} \mathrm{Ar} /{ }^{39} \mathrm{Ar}$ plateau age of $34.36 \pm 0.07 \mathrm{Ma}$ for hornblende from three sites) that is the largest early intrusion $(5 \times 10 \mathrm{~km})$ in the San Juan region.

The rhyolite-dacite dome field at Barret Creek constitutes the only sizable area of silicic volcanism, anywhere in the San Juan region, in the time interval between peak activity of the North Pass cycle at $32 \mathrm{Ma}$ and inception of ignimbrite eruptions from the Platoro caldera complex in the southeastern mountains at 29.4 Ma. The most dacitic lavas are compositionally and petrographically similar to the voluminous Fish Canyon Tuff, documenting that generation of this regionally distinctive magma type began relatively early in the San Juan region, well north of the area that would become La Garita caldera (the 34.0-Ma Badger Creek Tuff, erupted from a caldera source in the Sawatch Range, is also petrologically similar to the Fish Canyon Tuff). The Barret Creek lavas, which possibly represent an aborted or failed caldera system, provide a further bridge in the transition between earlier ignimbrite activity along the Sawatch trend and younger silicic centers in the San Juan region.

\section{Younger Eruptions from Other San Juan Calderas (28.3-26.9 Ma)}

The northeastern San Juan Mountains were formerly blanketed by regional Oligocene ignimbrites erupted from areas to the south and west, and widespread remnants of this cover have survived erosion. Locally erupted intermediate-composition lava flows and volcaniclastic rocks interfinger with these ignimbrites within the map area. The following sections summarize new age data and aspects of these tuffs that bear on development of the North Pass and Cochetopa Park calderas.

\section{Sapinero Mesa Tuff}

The Sapinero Mesa Tuff (Tws), a crystal-poor rhyolite erupted from the western San Juan caldera cluster at $28.27 \pm 0.06 \mathrm{Ma}$ (table 2), is among the largest ignimbrites in the San Juan region, with an estimated volume of $1,000 \mathrm{~km}^{3}$ or more (Lipman and others, 1973; Bove and others, 2001). With the unit now recognized as Saguache Creek Tuff excluded from this ignimbrite, the preserved distribution of Sapinero Mesa Tuff is mainly confined to scattered erosional remnants in the western and northern map area. In these distal areas, the Sapinero Mesa Tuff is rarely more than $20 \mathrm{~m}$ thick, only partly welded, and light gray in color due to vapor-phase crystallization; phenocrysts are sparse, small, and more broken than in more proximal sites.

Small areas of lithologically similar ignimbrite are also discontinuously present just east of the map area along the Saguache paleovalley, especially in the tributary of Houselog Creek (LG), where the tuff has a similar sanidine ${ }^{40} \mathrm{Ar} /{ }^{39} \mathrm{Ar}$ age $(28.20 \pm 0.06 \mathrm{Ma})$ and reverse paleomagnetic pole position as the Sapinero Mesa Tuff farther west (Lipman and McIntosh, 2008). This apparently distal eastern area of thin Sapinero Mesa Tuff probably was channeled down the Saguache paleovalley, resulting in an overall distribution much like that depicted previously (Steven and Lipman, 1976, fig. 10), even though the thick densely welded ignimbrite sheet formerly identified as Sapinero Mesa in this area is now recognized to be the older Saguache Creek Tuff.

\section{Fish Canyon Tuff}

The crystal-rich dacitic Fish Canyon Tuff (Tfc), erupted from the 75- x 35-km La Garita caldera at 28.02 Ma (fig. 2), is the most voluminous ignimbrite in the SRMVF, with a volume greater than 5,000 $\mathrm{km}^{3}$ (Lipman and others, 1970; Lipman, 2000; Bachmann and others, 2002). Seven additional large ignimbrite sheets erupted from within La Garita caldera during the next $1.1 \mathrm{~m} . \mathrm{y}$. (table 1), forming the central caldera cluster (Lipman, 2000, 2006). The north margin of La Garita caldera is just south of the map area (fig. 2), and proximal Fish Canyon Tuff originally blanketed most or all of the northeastern San Juan region, banking out locally against paleotopographic highs such as the early central volcanoes. Within the North Pass caldera (photo 10, CD-ROM), the Fish Canyon Tuff is as much as $300 \mathrm{~m}$ thick, exceptionally densely welded, and widely preserved, indicating that the subsidence basin had been incompletely filled. Eruption of the Fish Canyon Tuff is also inferred to be closely intertwined with early development of the unusual caldera structure at Cochetopa Park, as discussed later.

\section{Carpenter Ridge and Wason Park Tuffs}

The Carpenter Ridge Tuff (Tcr), another $>1,000-\mathrm{km}^{3}$ ignimbrite erupted at $27.55 \pm 0.05 \mathrm{Ma}$ from the Bachelor caldera centrally within La Garita caldera (fig. 2), also once covered much of the northeastern San Juan region as a widespread thin sheet of densely welded crystal-poor rhyolite (photo 11, CD-ROM). This crystal-poor rhyolitic ignimbrite commonly contains a near-basal black vitrophyre and a central lithophysal zone, even where only a few tens of meters thick. In addition to its stratigraphic position above the Fish Canyon Tuff, the Carpenter Ridge can be distinguished in outcrop from the otherwise similar-appearing Saguache Creek Tuff by the presence of biotite phenocrysts. Proximal Sapinero Mesa Tuff closely resembles the Carpenter Ridge, but the distal Sapinero Mesa within the map area is only partly welded and lacks lithophysae. The Carpenter Ridge Tuff provides an important stratigraphic 
marker that helps distinguish faults and structures associated with eruption of the Fish Canyon Tuff from younger features formed during later subsidence at Cochetopa Park.

The Wason Park Tuff (Tw), a crystal-rich rhyolite erupted at 27.38 $\pm 0.05 \mathrm{Ma}$ from the South River caldera of the central San Juan cluster (fig. 2), mainly ponded within La Garita caldera, but locally escaped to the northeast following paleovalleys that breached the caldera wall (photo 12, CD-ROM). The most northeastern preserved outcrops of the Wason Park tuff are at Sheep Creek (northwest TM), against the east margin of the North Pass caldera, which demonstrates that this side of the caldera remained a topographic low nearly 5 m.y. after initial subsidence.

\section{Younger Intermediate-Composition Lava Flows}

Several mesa-capping erosional remnants of aphanitic to sparsely porphyritic andesitic to dacitic lava southeast of the North Pass caldera (younger lava flows, fig. 4) were erupted concurrently with ignimbrites from the central caldera cluster. Older flows that overlie the Fish Canyon Tuff in the vicinity of Mount Lion (photo 13, CD-ROM; LM) have yielded ages of 28.0-27.6 Ma (7 samples) on groundmass separates (Lipman and McIntosh, 2008); flows on the west flank of Lake Mountain are overlain by a thin remnant of Carpenter Ridge Tuff (27.55 $\mathrm{Ma})$, stratigraphically consistent with the isotopic results. These flows are thus equivalent to the Huerto Andesite (Thu), a major unit within and adjacent to the La Garita caldera to the southwest.

Other mesa-capping flows that overlie the Carpenter Ridge Tuff directly south of the North Pass caldera (fig. 2) have ages of 27.51-27.46 Ma, consistent with eruption before the Wason Park Tuff at 27.38 Ma. These flows, which have no stratigraphic counterparts in northern parts of the central caldera cluster, are informally designated the andesite of Mountain Lion Creek (Tal). Most of these localities were previously interpreted as Miocene Hinsdale Formation (Tweto, 1979), but only one small mesa cap of Hinsdale lava has been confirmed in the northeastern San Juan region - a flow on Houghland Hill just east of the map area (fig. 4; LMNE) dated at 21.81 $\pm 0.21 \mathrm{Ma}$.

\section{Rocks of the San Luis Caldera Complex}

Three compositionally diverse ignimbrites and associated lavas of the San Luis caldera complex (photos 14-16, CD-ROM), nested along the northwest side of La Garita caldera (figs. 2, 10), are the youngest major eruptions from the central San Juan caldera cluster, other than the Snowshoe Mountain Tuff from the Creede caldera farther south (Lipman, 2000, 2006). New age results show that these three ignimbrites were erupted geologically rapidly between $26.91 \pm 0.02$ and $26.90 \pm 0.02 \mathrm{Ma}$ (table 2, weighted means), a time span too brief to resolve reliably by ${ }^{40} \mathrm{Ar} /{ }^{39} \mathrm{Ar}$ dating (Lipman and McIntosh,
2008). The eruptive history of the San Luis caldera complex (Lipman, 2000) is summarized briefly, because the last-erupted Nelson Mountain Tuff is interpreted as closely intertwined with subsidence at Cochetopa Park.

\section{Rat Creek Tuff}

The initial ignimbrite erupted from the San Luis caldera complex, the Rat Creek Tuff, is compositionally zoned (73-65\% $\mathrm{SiO}_{2}$ ) from weakly indurated light-tan crystal-poor rhyolite (Trr) upward into welded crystal-rich dacite (Trdn). The Rat Creek Tuff is the smallest of the San Luis ignimbrites in estimated volume $\left(\sim 150 \mathrm{~km}^{3}\right)$ and the most restricted in known extent, and its source is the least understood (Lipman, 2000, p. 32-33). Within the map area, preserved exposures of the Rat Creek Tuff are limited to weakly welded distal ignimbrite along the northeast-trending Los Pinos graben (fig. 5; RC, CS). Eight samples from geographically widespread sites have a weightedmean laser-fusion sanidine age of $26.91 \pm 0.02 \mathrm{Ma}$.

\section{Cebolla Creek Tuff}

The Cebolla Creek Tuff (Tcc) is a distinctive compositionally uniform ignimbrite (photo $15, \mathrm{CD}-\mathrm{ROM}$ ) of gray to lightbrown, weakly vapor-phase-devitrified mafic dacite (62-66\% $\mathrm{SiO}_{2} ; 25-40 \%$ phenocrysts of plagioclase, biotite, hornblende, sparse clinopyroxene). In contrast to other dacitic tuffs of the San Luis caldera complex, the Cebolla Creek lacks sanidine, and hornblende is abundant. Hornblende and biotite plateau ages for this unit (27.07-27.13 Ma) are about $0.2 \mathrm{~m}$.y. older than sanidine ages for the underlying Rat Creek Tuff (table 2). Such slightly older ages for these mafic minerals relative to sanidine are fairly common among dated volcanic rocks in the San Juan region (Lipman and McIntosh, 2008).

Like the underlying Rat Creek Tuff, exposures of outflow Cebolla Creek deposits are weakly welded and are limited to ponded fill within the northern La Garita caldera and along the Los Pinos graben (fig. 5). These lower ignimbrite sheets were widely eroded prior to eruption of the overlying Nelson Mountain Tuff, which rests directly on older units in many places within the general distribution area of the Rat Creek and Cebolla Creek Tuffs. The source caldera for the Cebolla Creek Tuff, although now largely concealed beneath the Nelson Mountain caldera source and flanking postcollapse volcanoes, appears to be the largest among the three calderas of the San Luis complex, with dimensions of $12 \times 17 \mathrm{~km}$ at present erosional levels (fig. 10, sheet 2).

\section{Nelson Mountain Tuff}

This unit includes a regional ignimbrite sheet and thick intracaldera fill; like the Rat Creek Tuff, it grades upward in composition (73-63\% $\mathrm{SiO}_{2}$ ) from weakly welded crystal-poor rhyolite (Tnr) to densely welded dark crystal-rich dacite (Tnd). The Nelson Mountain Tuff is the most densely welded and voluminous outflow deposit erupted from the San Luis caldera complex (estimated $>500 \mathrm{~km}^{3}$ ), and its eruption was followed 
by growth of large volcanoes on the east and west caldera flanks (Stewart Peak Volcanics, Baldy Cinco Dacite), roughly concurrent with resurgent uplift of the caldera interior (Steven and Lipman, 1976; Lipman, 2000, 2006).

Exposed intracaldera Nelson Mountain Tuff is more than $800 \mathrm{~m}$ thick on San Luis Peak, and erosional remnants of the outflow sheet are preserved widely around southwest and southeast sides of the San Luis caldera complex, where this ignimbrite spread across northern parts of La Garita caldera (Lipman, 2006). A northeastern outflow lobe of the Nelson Mountain was able to cross the La Garita caldera wall, following paleovalleys of the Los Pinos and Cochetopa Creek grabens (figs. 4-5; RC, CS) into Cochetopa Park caldera (photos 14, 16A, CD-ROM), and a weakly welded distal facies of this unit (photo 16B, CD-ROM) reached the southeast side of the Cochetopa Park caldera (fig. 4). The northeast lobe was previously considered to be a separate younger ignimbrite sheet (tuff of Cochetopa Creek or Cochetopa Park Tuff) interpreted to have erupted from the Cochetopa Park caldera (Steven and Bieniewski, 1977; Olson and Steven, 1976a; Olson, 1988), but more detailed mapping, paleomagnetic pole positions, and age determinations have documented its correlation as outflow Nelson Mountain Tuff (Lipman, 2000, p. 37).

New single-crystal sanidine age determinations for the Nelson Mountain Tuff, both outflow and intracaldera (table 2; Lipman and McIntosh, 2008), have resolved some enigmatic problems concerning this unit. Previously determined ${ }^{40} \mathrm{Ar} /{ }^{39} \mathrm{Ar}$ incremental-heating plateau ages on multiple-grain sanidine concentrates, although analytically reproducible, differed by as much as 1 m.y. among samples from different geographic localities and for intracaldera versus outflow parts of this ignimbrite unit (fig. 6; discussion in Lipman, 2000). The new single-crystal laser-fusion ages document the presence of sanidine xenocrysts, and also grains with degassed melt inclusions, that yielded scattered ages substantially older or younger than the average for closely grouped grains in individual samples (Lipman and McIntosh, 2008). When statistically anomalous crystals are excluded, sanidine from eight outflow samples yield a weighted mean age of $26.90 \pm 0.02 \mathrm{Ma}$, and two samples of intracaldera Nelson Mountain have a mean of $26.91 \pm 0.04 \mathrm{Ma}$ (table 2).

The new mapping has also shown that many areas of ridgecapping ignimbrite north of the Los Pinos graben and extending nearly to the Gunnison valley, which were depicted as Nelson Mountain Tuff and (or) tuff of Cochetopa Creek (Cochetopa Park Tuff) on previously published geologic quadrangle maps (Olson, 1976a,b; Olson and Steven, 1976a,b; Olson, 1988), instead consist entirely of diverse pre-Nelson-Mountain regional units, including at various sites the Wall Mountain, Saguache Creek, Fish Canyon, and Carpenter Ridge Tuffs. The Nelson Mountain Tuff and earlier tuffs from the San Luis complex may well have originally been deposited over sizable areas to the north, but as the youngest and topographically highest deposits, they have been entirely eroded. No tuff of Cochetopa Creek or Nelson Mountain Tuff remains preserved north of the Cochetopa Park caldera.

There is a sizable discrepancy between the volume of the Nelson Mountain Tuff and the amount of subsidence at its eruptive source. The widespread outflow and thick intracaldera accumulation of the Nelson Mountain Tuff $\left(500 \mathrm{~km}^{3}\right)$ constitutes the largest of the three San Luis ignimbrites in eruptive volume (table 1). In contrast, the subsidence basin at its eruptive source within the San Luis caldera complex is anomalously small relative to the estimated eruptive volume. The basin defined by the unconformity between wall rocks and caldera fill is $10 \times 15 \mathrm{~km}$ (fig. 10), but the southern third of the basin is a truncated paleovalley, as documented by mapping and mineralexploration data (Lipman, 2000). The paleovalley is well outside of the structurally subsided block, which has estimated maximum dimensions of only about $8 \times 10 \mathrm{~km}$ and an area of about $65 \mathrm{~km}^{2}$. About $8 \mathrm{~km}$ average caldera subsidence would thus be needed to accommodate the $500 \mathrm{~km}^{3}$ erupted volume of the Nelson Mountain Tuff, but the asymmetric trap-door subsidence geometry at this caldera (Lipman, 2000) permits only about $500 \mathrm{~m}$ of subsidence on the north side of the caldera and no more than 1.5-2 km at the more deeply subsided south side. This apparent inconsistency between eruptive and subsidence volumes associated with eruption of the Nelson Mountain Tuff is interpreted as the result of complex interrelations with subsidence at the much larger Cochetopa Park caldera centered $30 \mathrm{~km}$ to the northeast.

\section{Cochetopa Park Caldera: Relation to Nelson Mountain Tuff (26.9 Ma)}

Cochetopa Park (cover photo) is among the larger and most morphologically obvious caldera basins (about $30 \mathrm{~km}$ in diameter) in the region (photos 17-19, CD-ROM), but its depth of subsidence appears to be less than for other San Juan calderas. Subsidence was only about $300 \mathrm{~m}$ along the south margin, where constrained by downdropped Saguache Creek Tuff and underlying rocks on the caldera floor (SA), just south of the map area (Lipman, 2006). Subsidence was as much as 700-800 $\mathrm{m}$ on the north side where precollapse lavas on the caldera floor are structurally coherent, as shown by the continuity of andesite dikes and lava flows (photos 3C, 20, CD-ROM). In contrast, geometric modeling of other large San Juan calderas suggests structural subsidence of 3-5 km (Lipman, 1997), similar to caldera-fill sections exposed in tilted calderas elsewhere in the western United States (Seager and McCurry, 1988; Lipman 1993; John, 1995; John and others, 2008).

The earliest caldera-fill deposits at Cochetopa Park are thick massive aprons of coarse landslide breccia, banked against the inner caldera slopes (photos 20, 21, CD-ROM). This distribution is in contrast to slide breccias at other more deeply subsided calderas in the San Juan region, where the landslide deposits spread widely across the subsided basin and interfinger with thick intracaldera tuff. The location of slide breccias at Cochetopa Park, hanging on slopes of the inner caldera wall, is consistent with the relatively limited subsidence interpreted from offsets of the caldera floor. In places, distal Nelson Mountain Tuff directly overlies the landslide deposits (photo 16B, CD-ROM), documenting subsidence at Cochetopa 
Park and rapid slump failures of the oversteepened inner walls to generate the slide breccias during eruption of this ignimbrite, before it reached distal areas of deposition.

The landslide deposits reflect lithologies on the adjacent caldera rims: around the north side, breccia consisting of andesitic clasts (Tpba) is dominant, along with areally restricted lenses of monolithologic breccia derived from Saguache Creek Tuff (Tpbs); around the south and east sides are monolithologic slide breccias of shattered Fish Canyon Tuff (Tpbf; photo 21A-D, CD-ROM), in places containing sparse clasts derived from Carpenter Ridge Tuff (Tpbm; photo 21E, CD-ROM). Confident identification of the crystal-poor biotite-bearing rhyolite clasts as derived from the Carpenter Ridge Tuff, rather than lithologically similar Sapinero Mesa Tuff, is critical evidence in interpreting the time of major caldera subsidence. Sanidine ${ }^{40} \mathrm{Ar} /{ }^{39} \mathrm{Ar}$ ages on two clasts from the west and northeast caldera sectors are $27.59 \pm 0.05$ and $27.48 \pm 0.05 \mathrm{Ma}$ (table 2; Lipman and McIntosh, 2008), which confirm identity as Carpenter Ridge Tuff.

Some massive slide breccias of monolithologic Fish Canyon debris, characterized by closely packed clasts with little or no interstitial matrix fines (photos 21B-C, CD-ROM), were initially considered candidates for a hot emplacement mechanism, but random paleomagnetic pole orientations of clasts for sites both on west and southeast sides of the caldera are inconsistent with this hypothesis (Lipman and McIntosh, 2008, table 2).

The caldera was further filled by fanglomerates along caldera walls (photos 22, 23, CD-ROM) and a thick central pile of crystal-poor silicic lava flows of Cochetopa Dome Rhyolite (photos 18, 19, 24, CD-ROM), here named for compositionally distinctive rocks previously described only briefly (Steven and Lipman, 1976, p. 27; Lipman and McIntosh, 2008). The rhyolite flows on Cochetopa Dome overlie and are surrounded by thin nonwelded pyroclastic flow deposits, airfall ash, and tuffaceous sediments (cover photo). These lavas, the most petrologically evolved Oligocene rhyolites in the San Juan region (table 4), have ${ }^{40} \mathrm{Ar}{ }^{139} \mathrm{Ar}$ ages (weighted mean of eight samples: $26.86 \pm 0.03$ ) that are only slightly younger than the Nelson Mountain Tuff (26.90 \pm 0.02$)$. Although subsidence is relatively modest in outer parts of the caldera, based on the floor geometry, exposures are inadequate to exclude deeper subsidence centrally within this little-eroded caldera. Cochetopa Park is also the site of a large Bouguer gravity low (25-30 mgal; Plouff and Pakiser, 1972; Drenth and Keller, 2004), suggesting the presence of thick low-density fill in central parts of the caldera and (or) a shallow subcaldera silicic pluton.

The morphologic preservation of the Cochetopa Park caldera is especially striking (fig. 5; cover photo; photo 17 , CD-ROM). It is among the few calderas in the SRMVF for which the original topographic rims can still be reconstructed with confidence (fig. 4). Survival of the constructional geometry at Cochetopa Park caldera is due to a combination of (1) late development, thereby less obscured by subsequent volcanism; (2) relatively shallow subsidence and only a modest volume of postcaldera volcanism, thus never filled by dense rocks that would resist erosional excavation; (3) partial fill by weakly indurated tuffaceous sediments that have been exhumed geologically recently; and (4) presence of erosion-resistant rocks (Precambrian) at the present-day (and probable Tertiary) drainage outlet (Cochetopa Canyon) that has limited downcutting and dissection of the caldera basin. The contrasting lack of morphologic expression at the North Pass caldera reflects the absence of all these factors.

The time of collapse at Cochetopa Park caldera and identity of an associated regional ignimbrite have been long-standing problems (Steven and Lipman, 1976, p. 22-25; Lipman, 2000 , p. 37). Cochetopa Park caldera was previously interpreted as associated with eruption of the tuff of Cochetopa Creek (Steven and Bieniewski, 1977; Olson and Steven, 1976a; Olson, 1988), but all rocks south of Cochetopa Park caldera formerly interpreted as tuff of Cochetopa Creek are now known to be Nelson Mountain Tuff (Lipman, 2000). My mapping also shows that all rocks previously interpreted as tuff of Cochetopa Creek north of the caldera are diverse ignimbrite units older than the Nelson Mountain Tuff. Based on clasts in the slide breccias deposited along the caldera wall, the timing of last major subsidence at Cochetopa Park is now firmly established as postdating eruption of the Fish Canyon and Carpenter Ridge Tuffs. All younger large-volume ignimbrite sheets were demonstrably erupted from vents to the south, within the central San Juan caldera cluster. As a result of these reinterpretations, no tuff of Cochetopa Creek or other obvious late ignimbrite sheets remain that could have had an eruptive source from the Cochetopa Park caldera, even though this large morphologic and structural basin clearly formed by subsidence.

As reinterpreted here, the Cochetopa Park area has been a site of recurrent structural events associated with several large eruptions, perhaps including the Luders Creek Tuff at 32.2 Ma, followed by graben formation and possible modest subsidence during Fish Canyon eruptions of La Garita cycle at 28.0 Ma. Indicators for events associated with eruption of the Fish Canyon Tuff include (1) formation of the northeast-trending Los Pinos and parallel Cochetopa Creek grabens (figs. 4, 5) during or after eruption of the Fish Canyon Tuff, but prior to eruption of the Carpenter Ridge Tuff at 27.55 Ma (Lipman, 2000); (2) development of fault-scarp breccias in Fish Canyon Tuff where it is downdropped along the west margin of Cochetopa Park caldera (west CS), prior to emplacement of the Carpenter Ridge Tuff; (3) exceptionally thick densely welded Fish Canyon Tuff $(<300 \mathrm{~m})$ that is locally preserved where deposited against steep slopes along the southwest margin of Cochetopa Park caldera; and (4) post-Fish Canyon andesite flows northeast of Cochetopa Park, which predate the Carpenter Ridge Tuff and are analogous in stratigraphic position to the caldera-related Huerto Andesite to the south. Thus, the Cochetopa Park area may have been the site of a northerly fourth segment of caldera subsidence during eruption of the Fish Canyon Tuff, directly on line with the composite La Garita structure (fig. 2), which then would have a north-south extent of about $100 \mathrm{~km}$. No deep subsidence in the Cochetopa Park area seems likely at that time, however, as indicated by the apparent absence of thick ponded Carpenter Ridge Tuff that would have accumulated within the resulting basin.

Much of the record of structural development in the Cochetopa Park area during the Fish Canyon eruptions is concealed by the sizable later subsidence event that formed most of 
the presently exposed features of the caldera basin. This beautifully preserved structure owes its modern appearance largely to passive collapse during discharge of the 26.9-Ma Nelson Mountain Tuff $\left(\sim 500 \mathrm{~km}^{3}\right)$, from the underfit depression within the San Luis caldera complex $30 \mathrm{~km}$ to the southwest. Evidence is strong that the Nelson Mountain Tuff erupted from the San Luis complex (Lipman, 2000) but is completely lacking for any venting from the Cochetopa area. The preserved distribution of outflow Nelson Mountain Tuff is symmetrical around the San Luis complex, while Cochetopa Park is at the northeastern distal limit of the distribution of this tuff. Intracaldera Nelson Mountain Tuff is $>800 \mathrm{~m}$ thick, densely welded, and propylitically altered within the San Luis caldera system (Lipman, 2000, 2006), while preserved exposures of the Nelson Mountain Tuff become nonwelded and wedge out within eastern parts of Cochetopa Park caldera. Neither Nelson Mountain nor the earlier Fish Canyon Tuff accumulated to a multi-kilometer thickness at Cochetopa Park, nor did they acquire the welding and alteration features typical of intracaldera deposits within other San Juan calderas. Relatively shallow caldera collapse is also indicated by the widespread accumulation of landslide and talus breccias high along the inner caldera walls, rather than farther downslope and across the caldera floor as observed at more deeply subsided San Juan calderas (Lipman, 1976, 2000).

During the Nelson Mountain eruption, magma is interpreted to have moved from the Cochetopa to San Luis areas along a southwest-trending dike system, expressed at the surface by the large Cochetopa graben (Lipman and McIntosh, 2008). Cochetopa Park caldera must have begun to subside before or early during eruption of the compositionally zoned Nelson Mountain Tuff (crystal-poor rhyolite to crystal-rich dacite), as evidenced by deposition of rhyolite and thick dacite within western parts of the caldera (photos 14, 16A, CD-ROM), after landslides had already been generated from oversteepened caldera walls. Such passive (noneruptive) subsidence at a site distant from the associated ignimbrite vent is uncommon. Previously, such a configuration appears to have been thoroughly documented only for the much smaller 1912 eruption ( $\sim 13 \mathrm{~km}^{3}$ magma volume) from Novarupta crater in the Aleutians, where the main caldera collapse was $10 \mathrm{~km}$ distant at Katmai volcano (Hildreth and Fierstein, 2000). A geometrically somewhat similar analog, involving linked subsidences, may be the paired ignimbrites that erupted concurrently from the Rotorua and Ohakuri calderas in the Taupo zone of New Zealand (Gravley and others, 2007). Another geometrically comparable configuration could be the genetically enigmatic Mono Basin in eastern California, which is connected to the Long Valley caldera by a zone of extensional faults; the Bishop Tuff erupted from Long Valley at $0.76 \mathrm{Ma}$, without known concurrent eruptive activity at Mono Basin $20 \mathrm{~km}$ to the north (Bailey and others, 1976).

\section{Structure}

Structural features of the northeastern San Juan Mountains involve complex interactions between regional northeast-trending graben systems that were influenced by structural grain in the Precambrian craton; diverse localized faulting associated with volcanism, especially the large calderas; and effects of regional extension associated with inception of the north-south Rio Grande rift zone (Lipman, 2000, fig. 14).

\section{Northeast-Trending Graben Faults}

Several linear grabens and other faults adjacent to calderas appear largely to have been established during segmented subsidence of La Garita caldera, then passively buried by younger ignimbrite sheets and lava flows (photos 11A, 14, CD-ROM). These include the Los Pinos and Cochetopa Creek grabens (figs. 4, 5), which connect the northern La Garita segment to the Cochetopa Park caldera at the southwest margin of the map area (RC, CS), and probable obscure faults of similar trend that localized the elongate high-level intrusion (34.4 Ma) in the Needle Creek area (WB).

\section{Caldera Faults}

Many faults are present within the map area, but erosion levels are insufficient to expose large-displacement ring faults related to deep caldera collapse, such as those present within the Lake City and Silverton calderas in the western San Juan Mountains (Steven and Lipman, 1976). Exposed peripheral faults of the Cochetopa Park caldera can accommodate only modest subsidence; either larger faults are present more centrally within the caldera, or total subsidence was more modest than at most other San Juan calderas.

At Cochetopa Park, peripheral arcuate faults along the northwest and south margins of the caldera basin, which have displacements down toward the caldera interior and bound subsided caldera floor rocks of the Conejos Formation, appear to permit, at most, a few hundred meters of subsidence. The southern arcuate fault (CP, south of the map area; Lipman, 2006) has a maximum of about $250 \mathrm{~m}$ of displacement, as marked by downdropped Saguache Creek Tuff. On the northwest side of the caldera, a series of faults step down Precambrian and Mesozoic units in increments of a few tens of meters each toward the caldera interior; these are oriented appropriately to accommodate a portion of the 400-600 m maximum subsidence of Conejos lavas and breccias that make up the outer caldera floor in this area. Some of these faults may mark hinge zones that accommodated initial caldera downsag along zones of relatively modest peripheral subsidence, compared to other more deeply subsided San Juan calderas. Much of the northern arcuate fault system is interpreted to lie concealed beneath subsidence-related landslide breccia and fanglomerate (units Tpba, Tpcf; photo 20, CD-ROM). Some monolithologic slide breccias appear to represent shattered slump blocks that detached along faults associated with inward-sagging caldera walls, then moved semicoherently partway down into the subsiding basin.

No peripheral faults are exposed in eastern Cochetopa Park, but a linear array of north-trending faults along the west margin, north of McDonough Reservoir (CS, RC), appears related, at least in part, to recurrent caldera subsidence. This 
set of faults is designated the Ralston Creek fault zone, for the prominent tributary of Los Pinos Creek that transects the fault array where it is widest and best developed. These faults clearly displace the Sapinero Mesa Tuff and older units of the Conejos Formation, but complex relations with the Fish Canyon Tuff suggest offsets closely associated with emplacement of this ignimbrite. The Ralston Creek faults merge to the south with structures of the Los Pinos graben that predate emplacement of the Carpenter Ridge Tuff, and much of their displacement may have been concurrent with subsidence adjacent to north margins of the composite La Garita caldera during eruption of the Fish Canyon Tuff. Such an interpretation is supported by intricate distribution of shattered Fish Canyon Tuff (Tfcb) along some fault segments, which merge with adjacent segments that appear concealed beneath coherent welded tuff of the same ignimbrite. Relations between brecciated and coherent tuff are gradational, and in places lower brecciated zones in the Fish Canyon are overlain by unbroken tuff, suggesting that some brecciation resulted from downslope detachment motion within fault-bounded blocks. In places, the brecciated Fish Canyon Tuff mapped as fault related (Tfcb) is also difficult to distinguish in appearance from the monolithologic caldera-margin landslide breccia (Tpbf) that formed during subsidence of the Cochetopa Park caldera, and some areas of breccia may have been misinterpreted. Additionally, the Ralston Creek fault array merges with the projection of northern peripheral faults of the Cochetopa Park caldera, and displacements are progressively down to the east (toward the caldera). Thus, these structures may have moved recurrently and accommodated subsidence of this caldera during eruption of the Nelson Mountain Tuff. Vegetative cover and steep slopes obscure many features of these intricate faults, but exposures are sufficient to document structural relations that are unlike caldera-related faults elsewhere in the region.

No exposed faults are clearly associated with the North Pass caldera. Small faults, with northerly trends along the west margin of this caldera (NP), drop rocks interpreted as part of the caldera-fill sequence down to the east, toward the caldera. These faults may continue farther to the north and south than mapped, along linear valleys where contact relations are obscured by surficial deposits and heavy vegetation. The linear trends and small displacements seem plausible for a regional structure. Nevertheless, these faults appear to die out in or be covered by tuffaceous sediment, interpreted as volcaniclastic fill of the North Pass caldera, suggesting that their movement may have been concurrent with caldera formation. In contrast, the large Sheep Creek fault system along the east side of the North Pass caldera is interpreted as primarily a regional extensional feature associated with the Rio Grande rift system.

\section{Rio Grande Rift Faults and Associated Volcanism}

During late stages of San Juan volcanism, the Rio Grande rift zone became active within the present-day San Luis Valley area to the east of the San Juan Mountains (fig. 1; Lipman and Mehnert, 1975), and a few north- to northeast-trending faults within the map area have appropriate geometry and timing to reflect such regional tectonism. Regional structural trends of the volcanic rocks in the map area-flat in the western part, hinged to the east near the present-day Continental Divide, and dropped mainly down to the west by north-trending faults that have displacements antithetic to the main San Luis Valley segment of the rift zone - are strikingly similar to general trends in the southeastern San Juan region (Lipman, 1975). This structural style reverses just to the northeast of the map area, where volcanic rocks of the Bonanza center are tilted to the west, along faults that appear to constitute a structural transition toward the Sawatch Range-Upper Arkansas Valley segment of the Rio Grande rift zone.

Within the map area, northerly trending faults of the Sheep Creek zone (photo 12, CD-ROM) are the most prominent and largest rift-related structures (TM, west LM). Some of these faults cut the andesite of Mountain Lion Creek (Tal), dated at about 27.5 Ma east of Hat Mountain (GC), which documents relatively late movement. Several smaller faults of similar trend, in the Grouse Creek area farther to the west, displace the Fish Canyon Tuff and older rocks. Thinning, nondeposition, and (or) erosional removal of regional ignimbrite sheets, erupted from the central caldera complex (Carpenter Ridge, Wason Park, Nelson Mountain), on the uplifted east side of the Sheep Creek fault zone suggest that these structures initially may have become active during peak ignimbrite volcanism. The central sector and maximum offset along the Sheep Creek fault zone also coincide closely with the east margin of the North Pass caldera, indicating that structures of the caldera margin influenced location of the younger rift-related faults or that incipient rift faulting was already underway at the time of caldera subsidence.

Bimodal mafic-silicic volcanism, which regionally accompanies Miocene development of the Rio Grande rift system (Lipman and Mehnert, 1975), may have begun relatively early in the northeastern San Juan region. The highly-evolved rhyolite lavas on Cochetopa Dome and associated intrusive bodies, dated at 26.9-27.1 Ma, are only a few hundred thousand years younger than mesa-capping olivine-andesite flows within the map area (Tal, andesite of Mountain Lion Creek); these rocks may define the beginning of the transition to the bimodal suite that characterizes volcanism associated with the Rio Grande rift. Several small intrusions of high-silica rhyolite (Tcdi) are similar in composition and age to the flows of Cochetopa Dome Rhyolite within the caldera. These include a stubby dike elongated north-northeast, exposed at Deer Hill (RD) at the north margin of caldera-fill fanglomerate, and a similarly aligned trend of three equant plugs farther to the north, the largest of which is the conspicuous knob of Prosser Rock (RD; photo 25, CD-ROM). The more northerly trends of the rhyolite plugs, in contrast to the northeastern grain of the earlier caldera-related graben faults and associated Conejos-age intrusions, are an appropriate orientation for inception of rift-related regional extension. 


\section{DESCRIPTION OF MAP UNITS}

[Locations are indicated by abbreviations (fig. 3) for 7.5' quadrangles. For major volcanic units, phenocryst percentages are listed, with principal phases in order of abundance: bi, biotite; cpx, clinopyroxene; hbl, hornblende; pl, plagioclase; qz, quartz; sn, sanidine]

\section{SURFICIAL DEPOSITS}

Qal Alluvium (Holocene) - Silt, sand, gravel, and peaty material in valley bottoms. Locally includes small deposits of colluvium (Qc) and talus (Qt) at margins of valley bottoms

Qc Colluvium (Holocene) - Poorly sorted silt- to boulder-sized material on slopes and in steep valleys. Locally includes small alluvial, talus, landslide, and glacial-moraine deposits

QI Landslide deposits (Holocene and Pleistocene) - Lobate accumulations of poorly sorted soil and rock debris on slopes marked by hummocky morphology and downslope-facing scarps. Derived from bedrock and glacial deposits. Includes small earth-flow, block-slump, and block-slide deposits

Qf Alluvial-fan deposits (Holocene) - Generally poorly sorted material, ranging in size from silt to boulders, that grades into modern colluvium in upper parts of drainages. Only large low-angle fans are shown; smaller steep fan deposits are mapped with colluvium (Qc). Fan deposits largely predate outwash of Pinedale glaciation and are mostly derived from unglaciated drainages

Qt Talus (Holocene) - Angular rock fragments as much as $1 \mathrm{~m}$ in diameter forming talus cones, talus aprons, and scree slopes. Locally well sorted. Grades into colluvium (Qc) as sand and silt content increases

Qlo Older landslide deposits (Pleistocene) — Landslide deposits in which original hummocky morphology has become subdued due to erosion and sedimentation. Eroded landslide material forming high-standing erosional remnants

Qfo Older alluvial-fan deposits (Pleistocene) - High-standing erosional remnants of dissected alluvial fans, consisting mainly of volcanic clasts

\section{GLACIAL DEPOSITS}

Qm Moraine and till (Pleistocene; Pinedale glaciation) - Terminal and lateral moraines; thick valley-bottom till. Poorly sorted and generally unstratified clay, silt, and sand containing cobbles and boulders. Characterized by hummocky or ridgy topography. Some till has been mapped with colluvium (Qc)

Qg Glacial-outwash and other terrace gravels (Pleistocene; Pinedale glaciation) - Moderately sorted to well-sorted stratified terrace and fan deposits consisting of sand, gravel, and wellrounded boulders. In places, difficult to distinguish reliably from alluvial-fan terraces (Qf)

Qgo Older glacial-outwash and other stream gravels (Pleistocene; pre-Pinedale glaciation)-Deposits preserved as local erosional remnants of high-standing outwash terraces. Preserved mainly along ridge between Cochetopa Creek and Van Tassel Gulch (CP, CS). In places, difficult to distinguish reliably from older alluvial-fan deposits (Qfo)

\section{OLD SURFICIAL DEPOSITS}

QTI High-level landslide or debris-flow deposits (Quaternary and Tertiary?)—Erosional patches high on valley walls of Long Branch (SM), containing large blocks of Bonanza and Saguache Creek Tuffs; puzzling erosional hill of unconsolidated bouldery deposit, containing clasts of dacitic Nelson Mountain Tuff (Tnd) and tuffaceous breccia (CS). Emplacement possibly related to subsidence of the Cochetopa Park caldera. Thickness, $>50 \mathrm{~m}$

Deeply dissected alluvial-fan deposits (Quaternary and Tertiary?) - Mainly angular clasts of Precambrian metamorphic rocks $(\mathrm{p} \in \mathrm{m})$ in Iris and Iris NW quadrangles. In places, difficult to distinguish from float derived from underlying Precambrian bedrock; in others, merges with younger colluvium (QC). Previously mapped on the Iris quadrangle as Tertiary gravel deposits and inferred to underlie the Fish Canyon Tuff (Olson, 1976b); mapped on the Iris NW quadrangle as Rat Creek Tuff (Hedlund and Olson, 1974) 
High-level gravel deposits (Quaternary and Tertiary?) - Local erosional remnants of old stream gravels containing mainly volcanic clasts, especially in northeastern map area. Merges with and in places difficult to distinguish from older alluvial-fan deposits (Qfo)

\section{MIOCENE POSTCALDERA VOLCANIC ROCKS}

Hinsdale Formation - The Hinsdale Formation is an assemblage of silicic alkalic basalt (trachybasalt) and basaltic-andesite lavas $\left(50-60 \% \mathrm{SiO}_{2}\right)$ erupted from widely scattered vents, with volumetrically subordinate silicic rhyolite erupted as lava domes and tuffs. These rocks, emplaced intermittently between about 26.5 Ma and $14 \mathrm{Ma}$ in the central and northeastern San Juan Mountains, constitute a bimodal volcanic suite that accompanied regional extension along the Rio Grande rift zone (Lipman and Mehnert, 1975)

Thb Mafic flows-Small mesa-capping erosional remnants of fine-grained dark-gray basaltic andesite that overlie Wall Mountain Tuff (Twm) along the ridge crest between Sugar and Right Creeks (northwestern $\mathrm{SH}$ ). Small sparse olivine phenocrysts, partly altered to rusty brown iddingsite, are typical; these lavas appear less altered and more mafic than adjacent andesite mapped as flows of the Conejos Formation along the same ridge. Tentatively included in the Hinsdale Formation, in continuity with prior assignment by Olson and others (1975); lacking isotopic ages, may be an older unit. The only basaltic flow in the northeastern San Juan region with a confirmed Hinsdale age $\left({ }^{40} \mathrm{Ar} /{ }^{39} \mathrm{Ar}\right.$ groundmass age: $\left.21.81 \pm 0.21 \mathrm{Ma}\right)$ caps Houghland Hill, just east of the map area (LG). Thickness 0-50 m

\section{OLIGOCENE VOLCANIC ROCKS}

\section{ROCKS OF COCHETOPA PARK CALDERA AND SAN LUIS CALDERA COMPLEX}

The San Luis caldera complex (photo 26, CD-ROM) is the composite source for three successive large ignimbrite eruptions (fig. 10) and associated overlapping caldera-subsidence events that successively produced the Rat Creek, Cebolla Creek, and Nelson Mountain Tuffs (Lipman, 2000, 2006). After each ignimbrite eruption, the associated caldera was variably filled by andesitic to rhyolitic lavas. Recent isotopic ages on sanidine phenocrysts by single-crystal laser-fusion ${ }^{40} \mathrm{Ar} /{ }^{39} \mathrm{Ar}$ methods tightly bracket the three regional ignimbrites at $26.90 \mathrm{Ma}$ (Lipman and McIntosh, 2008), greatly improving the age resolution for this eruptive sequence compared to prior isotopic results (fig. 6). Cochetopa Park caldera is interpreted as having last subsided passively during eruption of the Nelson Mountain Tuff from the San Luis complex, after which it was filled by volcaniclastic sediments and rhyolitic lavas

\section{Rocks of the Nelson Mountain caldera cycle}

The Nelson Mountain Tuff (photo 16, CD-ROM) is the most voluminous outflow deposit erupted from within the San Luis caldera complex, and its eruption was followed by growth of large postcaldera volcanoes on its east and west flanks (Stewart Peak Volcanics, Baldy Cinco Dacite), roughly concurrent with resurgent uplift of the caldera interior (Lipman, 2000). Our mapping shows that the Cochetopa Park caldera (probably polycyclic, with some structural subsidence during La Garita caldera cycle and eruption of the Fish Canyon Tuff) last subsided passively during early stages of the Nelson Mountain eruption, then was flooded by later-erupted Nelson Mountain Tuff erupted from vents within the San Luis complex. No evidence exists to indicate that any large pyroclastic eruptions vented directly from within Cochetopa Park caldera; prior proposals for eruption of a tuff of Cochetopa Creek or Cochetopa Park Tuff of Olson (1988) from this caldera were based on regional miscorrelations between different geographic sectors of the Nelson Mountain Tuff (Lipman, 2000). Subsidence at Cochetopa was relatively modest in scale, no more than about $1 \mathrm{~km}$ vertically, compared to other San Juan ignimbrite calderas, and a downdropped segment of floor rocks (mainly Conejos Formation) is exposed on the north side of the caldera. The caldera is less deeply dissected than most other San Juan calderas, in part because of lower overall elevation and because the Precambrian granitic rocks in Cochetopa Canyon, the morphologic outlet, are relatively resistant to erosion. As a result, the filling history of the caldera is known only for late events, and the thickness of fill cannot be estimated for central parts of the caldera

\section{Caldera-Fill Flows and Intrusions}

After the last subsidence at the Cochetopa Park caldera during eruption of the Nelson Mountain Tuff from vents within the San Luis complex $30 \mathrm{~km}$ to the southwest, a sequence of viscous rhyolitic lava flows 
constructed the morphologic feature known as Cochetopa Dome near the center of the caldera (photos 18, 24, CD-ROM). The rhyolite flows overlie diverse volcaniclastic rocks that accumulated soon after caldera collapse, but some upper caldera-fill sedimentary deposits may have interfingered with the lava flows and filled intervening low moat areas between the dome and the inner caldera walls. Because the dome lavas are resistant and the volcaniclastic rocks are relatively readily eroded, Cochetopa Park caldera retains much of its primary morphology, with peripheral high points near the original topographic rim, a low sedimented moat, and a central constructional lava pile (fig. 5)

Cochetopa Dome Rhyolite - Three voluminous lava flows of phenocryst-poor high-silica rhyolite (lower, middle, and upper flows: Tcdl, Tcdm, Tcdu) form the bulk of Cochetopa Dome (photo 19, CD-ROM). A small area of crystal-rich rhyolite (Tcdc), exposed only as float, is a probable fourth flow. The main lava units contain locally mappable carapace breccias (Tcdx). In bulk-sample and phenocryst chemistry, these lavas are the most petrologically evolved rocks within the map area or anywhere among the voluminous Oligocene volcanic rocks of the San Juan region. In the sequence of main lava units on Cochetopa Dome, total phenocrysts decrease upward and sanidine compositions become more sodic as degree of magmatic fractionation increases (defined mainly from trace-element data, Lipman, 2004; table 5, CD ROM). North of Cochetopa Park caldera, small rhyolite plugs (Tcdi) that intrude older volcanic and prevolcanic rocks are similar in age and composition to the lavas on Cochetopa Dome and are probably additional parts of the same caldera-related magmatic system. Outcropping ridges on Cochetopa Dome have a pronounced northeast-trending grain, parallel to graben structures to the southwest and the elongate Needle Creek intrusion to the northeast, but no faults or other structural controls for these trends were recognized during mapping on the heavily vegetated slopes of Cochetopa Dome

Tcdu Upper lava flow-The highest flow on Cochetopa Dome is virtually aphyric light-gray highsilica rhyolite (76.3-76.9\% $\mathrm{SiO}_{2}$ ) preserving small nodules of nonhydrated obsidian (Apache tears) along a basal zone of perlitic glass; distribution of the obsidian Apache tears, which are present only in the upper flow, was helpful in tracing the basal contact of this lava through heavily forested slopes. ${ }^{40} \mathrm{Ar} /{ }^{39} \mathrm{Ar}$ age on obsidian, $26.91 \pm 0.20$. Maximum thickness, $>250 \mathrm{~m}$

Tcdc Crystal-rich flow-Tan rhyolite $\left(76.5-76.6 \% \mathrm{SiO}_{2}\right)$ containing $20-30 \%$ small phenocrysts (sn, pl, bi). Exposed only as float on southwest side of Cochetopa Dome, along a timbered bench between middle and upper main flows. Compositions of sanidine phenocrysts $\left(\mathrm{Or}_{56-58} \mathrm{Ab}_{42-43} \mathrm{An}_{0.6-0.8} \mathrm{Cn}_{0.1}\right)$ are distinctly more sodic than those for underlying crystal-poor rhyolite flows. ${ }^{40} \mathrm{Ar}{ }^{39} \mathrm{Ar}$ age on sanidine, $26.81 \pm 0.04 \mathrm{Ma}$. Thickness, $0-50 \mathrm{~m}$

Tcdm Middle lava flow - Gray to tan rhyolite (76.5-77.0\% $\mathrm{SiO}_{2} ; 1-2 \% \mathrm{sn}$, pl, qtz, bi) forming flowlaminated to massive cliffs around south side of Cochetopa Dome. Compositions of sparse sanidine phenocrysts $\left(\mathrm{Or}_{59-60} \mathrm{Ab}_{38-40} \mathrm{An}_{1.0-1.3} \mathrm{Cn}_{0.05-0.1}\right)$ are slightly more sodic than those for the underlying lower flow. ${ }^{40} \mathrm{Ar} /{ }^{39} \mathrm{Ar}$ age on sanidine, $26.88 \pm 0.05 \mathrm{Ma}$. Maximum thickness, $200 \mathrm{~m}$

Tcdx Glassy flow breccia - Locally mappable green-gray carapace breccia especially well exposed on northeast flank of the middle flow (Tcdm). Contains angular fragments to $1 \mathrm{~m}$ across. Thickness, 0-20 m

Tcdl Lower lava flow-Tan flow-layered rhyolite (75.3-75.8\% $\mathrm{SiO}_{2} ; 2-3 \% \mathrm{sn}$, pl, qtz, bi) exposed only low on the east flank of Cochetopa Dome, where steeply dipping pressure ramps mark the top of this flow. Compositions of sanidine phenocrysts $\left(\mathrm{Or}_{60-63} \mathrm{Ab}_{36-38} \mathrm{An}_{1.0-1.2} \mathrm{Cn}_{0.1-0.3}\right)$ are more potassic than those in overlying flows, but less than in caldera-related Nelson Mountain Tuff. This flow is the most phenocryst rich and the least geochemically evolved; it previously was mapped as landslide deposits (Tweto and others, 1976), perhaps because the ramp structures were interpreted as slump blocks. ${ }^{40} \mathrm{Ar} /{ }^{39} \mathrm{Ar}$ age on sanidine, $26.99 \pm 0.14 \mathrm{Ma}$. Thickness, $>125 \mathrm{~m}$

Tcdi Intrusions - Massive to flow-layered gray to tan crystal-poor rhyolite (75-79\% $\mathrm{SiO}_{2} ; 1-2 \%$ san, pl, qtz) forming equant plugs and elongate dike-like masses. Central parts of the Prosser Rock intrusion (RD) contain as much as $20 \%$ angular to rounded fragments of dark-gray aphanitic andesite in varying stages of disaggregation (photo $25, \mathrm{CD}-\mathrm{ROM}$ ) ${ }^{40} \mathrm{Ar} /{ }^{39} \mathrm{Ar}$ ages on sanidine: Prosser Rock intrusion, $27.14 \pm 0.05 \mathrm{Ma}$ for sample of uniform flow-laminated rhyolite and $27.08 \pm 0.05 \mathrm{Ma}$ for rhyolitic portion of andesite-charged sample; dike-like intrusion at Sage Park (RD), 27.07 $\pm 0.06 \mathrm{Ma}$. The slightly older ages suggest that these intrusions 
may have been precursors to the compositionally similar eruptions at Cochetopa Dome, rather than direct equivalents

\section{Caldera-Fill Volcaniclastic Rocks}

After deposition of the Nelson Mountain Tuff within the concurrently subsiding caldera at Cochetopa Park, the resulting basin was filled by a varied assemblage of landslide tongues from the oversteepened wall, caldera-margin fanglomerate, and fine-grained tuffaceous sediments that accumulated in the moat area, in part concurrently with eruption of rhyolitic lava flows (Cochetopa Dome Rhyolite) centrally within the caldera

Caldera-margin fanglomerate-Alluvial-fan deposits derived by stream erosion of the inner caldera walls (photo 22, CD-ROM). The fanglomerate is only weakly indurated, outcrops are rare, and most occurrences are cobble-strewn slopes. These deposits contain varying clast assemblages, reflecting diverse lithologies along different sectors of the caldera walls. The caldera-margin fanglomerates largely overlie but locally interfinger with the intracaldera tuffaceous sediments that dominate sedimentation in the moat (photo 19B, CD-ROM). The fanglomerate may be largely younger than the Cochetopa Dome Rhyolite, but no direct stratigraphic relation is preserved

Tpff Fanglomerate with clasts of Fish Canyon Tuff-Andesitic clasts are dominant, but scattered clasts of Fish Canyon Tuff (Tfc), as well as rare clasts of dacitic Luders Creek Tuff (Tld), are conspicuous. Best exposures are along Archuleta Creek (CP), along the east margin of Cochetopa Park caldera. Maximum thickness, $>200 \mathrm{~m}$

Tpcf Fanglomerate and sandstone, with clasts of andesitic and rare dacitic lava derived from the Conejos Formation - Typical caldera-fill deposits low along north caldera wall (photo 23, CD-ROM). Best exposures are low along ridges between Homestead and Townsite Gulches (ST). Maximum thickness, $>200 \mathrm{~m}$

Tpt Intracaldera tuffaceous sediments - White to gray tuffs and water-reworked sediments, including laminated lake-bed deposits, deltaic shallow-water sandstone in medial areas of the caldera moat, and coarser river-channel sandstone and local conglomerate in sites more proximal to inner walls of the caldera. Exposures are discontinuous and limited in vertical and lateral extent, due to weak induration of most of the unit and low topographic relief in the moat area. Widespread zeolitic alteration of originally glassy ash. ${ }^{40} \mathrm{Ar} /{ }^{39} \mathrm{Ar}$ ages on sanidine: $26.90 \pm 0.04 \mathrm{Ma}$ for pumice blocks east of Cochetopa Dome; $26.83 \pm 0.05 \mathrm{Ma}$ for small nonwelded ignimbrite deposit south of the dome. Based on phenocryst content, eruption of the dated tuff samples may have been associated with emplacement of the middle flow on the dome. Maximum exposed thickness, $>50 \mathrm{~m}$

Caldera-margin landslide breccias-Massive landslide deposits are widely distributed along lower parts of the gently sloping inner caldera wall (photo 21, CD-ROM). Most are monolithologic, or nearly so, and record dominant lithologies high on the adjacent sector of the caldera rim at the time of subsidence. Sparse matrix is microbreccia of the same lithologies as the clasts. Individual clasts are commonly $<1 \mathrm{~m}$, but large clasts are locally present, and a few seemingly coherent megablocks are as much as several hundred meters across. In places, at upper limits of map units, the landside breccias become more coherent and difficult to distinguish from in-place exposures of the same lithology exposed on the caldera wall. Several megablocks of andesite are parts of the slide breccia near upper map limits of this unit on the southeast slope of Sawtooth Mountain (ST), and a large slab of flow-layered dacite is enclosed by slide breccia along Dry Gulch at about 10,000 ft elev (CS-ST boundary). Emplacement of collapse-related landslide deposits along the inner caldera slope at Cochetopa contrasts with the breccia sheets that spread widely across the caldera floor and intertongue with intracaldera ignimbrite deposits at other calderas of the San Juan region and elsewhere (Lipman, 1976, 2000). This difference probably reflects shallower subsidence (on the order of $1 \mathrm{~km}$ or less) at the noneruptive Cochetopa Park caldera, in contrast to deeper subsidence $(2-5 \mathrm{~km})$ documented at many other calderas that were primary eruptive centers for associated ignimbrite eruptions

Tpbf Massive breccia with clasts solely of Fish Canyon Tuff-Monolithologic breccias consisting of Fish Canyon clasts (TfC) are exposed nearly continuously along the south and east 
margins of the caldera basin. Clast-supported texture, sparse matrix fines, angular blocks, and unfilled voids are consistent with modest transport distance. These slide deposits locally form rugged cliffs of well-indurated breccia (photo 21, CD-ROM), for example along the Saguache Park road in Mexican Joe Gulch (CP and adjacent SA to the south), where they previously were mapped as in-place Fish Canyon Tuff (Steven and others, 1974). Small patches of similar breccia, preserved on the west caldera margin along both sides of Los Pinos Creek (CS), are difficult to distinguish from other breccia deposits (Tfcb) of Fish Canyon clasts in the same area, which are inferred to have formed earlier in association with faulting along a graben related to subsidence of La Garita caldera. Thickness, 0-200 m

Tpbm Breccia with sparse clasts of Carpenter Ridge Tuff-Locally exposed breccia dominated by Fish Canyon fragments but containing mixed clast lithologies (photo 21D, CD-ROM); typically less indurated than the monolithologic breccia (Tpbf) and exposed mainly as float. Distributed discontinuously along the north margin of the caldera, roughly concordantly with preserved outcrops of in-place Carpenter Ridge Tuff (Tcr) on the caldera rim. The mixed-breccia unit is best exposed west of the Samora Creek road (northeast CP), along the Wolverine Creek trail (south RD), and in a small roadcut along Los Pinos Creek road (CS). Presence of Carpenter Ridge clasts in the landslide breccia assemblage is critical evidence for timing of the last major subsidence at Cochetopa Park caldera. The Carpenter Ridge clasts are densely welded red-brown tuff, characterized by sparse biotite phenocrysts. Sparse clasts of densely welded Saguache Creek Tuff (Tsc) are also locally mixed with dominant Fish Canyon blocks in the landslide deposits; clasts of Saguache Creek Tuff are distinguishable from Carpenter Ridge clasts in the field by absence of biotite. Identification of Carpenter Ridge clasts in critical localities has been confirmed by rock and phenocryst (sanidine) chemical analyses and by isotopic ages concordant with dated in-place samples of this tuff (less alkalic and 4.5 m.y. younger than Saguache Creek Tuff). ${ }^{40} \mathrm{Ar} /{ }^{39} \mathrm{Ar}$ age on sanidine from a Carpenter Ridge clast along the Los Pinos Creek road, 27.59 $\pm 0.05 \mathrm{Ma}$; for clast west of Samora Creek, 27.48 \pm 0.05 Ma. Thickness 0-25 m

Tpbs Breccia with clasts of Saguache Creek Tuff-A large breccia lens, consisting of monolithologic fragments of densely welded red-brown Saguache Creek Tuff (Tsc) lies low along the north caldera wall on the ridge south of Homestead Gulch (ST). This lens is interpreted as a landslide deposit emplaced into Cochetopa Park caldera, based on its location along the inner caldera slope and its low topographic elevation relative to scattered preserved outcrops of in-place Saguache Creek Tuff north of the caldera. Lithologically similar breccias consisting of Saguache Creek Tuff (Tscl), which were emplaced in paleovalleys by landslides active prior to eruption of the Fish Canyon Tuff, are present north of the caldera basin, and the Homestead Gulch locality could possibly be such a deposit. Thickness, 0-50 m

Tpbr Breccia with clasts of Conejos rhyolite lava-Small breccia lenses consisting of gray to tan crystal-poor rhyolite (Tcfr; $2-5 \% \mathrm{pl}$, bi). Best developed north of Archuleta Creek (CP) and in Myers Gulch (RD). Thickness, $0-100 \mathrm{~m}$

Tpbd Breccia with clasts of Conejos dacite lava - Small breccia lenses consisting of gray to tan porphyritic dacite (Tcd; $15-30 \% \mathrm{pl}, \mathrm{bi}, \mathrm{cpx} / \mathrm{bh}$ ). Best developed along northwest caldera margin, between Dry Gulch and Willow Creek (CS-ST boundary). Thickness, 0-60 m

Tpba Breccia with clasts of Conejos andesite lava-Breccia consisting of fragments of dark-gray to brown andesite; widespread along the northern caldera margin. Phenocrysts are typically sparse, and clasts closely resemble in-place andesite lavas and volcaniclastic rocks of the Conejos Formation (Tca) higher on the inner caldera wall. Deposits are typically massive, but crude stratification locally parallels inward-dipping caldera-wall slopes. In places, difficult to distinguish from in-place volcaniclastic breccia of the Conejos Formation (Tcv). Thickest and most massive downslope from present-day high points on the north caldera rim (Sawtooth Mountain, Razor Creek Dome; photo 23, CD-ROM). Thickness, 0 to $>100 \mathrm{~m}$

\section{Nelson Mountain Tuff}

Caldera-forming eruption of the Nelson Mountain Tuff generated a regional ignimbrite sheet and thick intracaldera fill; the tuff grades upward in composition from rhyolite to dacite (73-63\% $\mathrm{SiO}_{2}$ ). Typical sanidine compositions are $\mathrm{Or}_{62-67} \mathrm{Ab}_{30-34} \mathrm{An}_{1.1-1.3} \mathrm{Cn}_{1.6-2.5}$ (Lipman and Weston, 2001), becoming more potassic and less homogeneous upward in section as bulk compositions change from rhyolite to dacite. Map subunits are primarily compositional and welding zones, rather than strictly sequential stratigraphic units. 
Normal magnetic polarity, with relatively steep inclination becoming nearly vertical high in some sections (Lipman, 2000, fig. 10). Weighted mean of single-crystal ${ }^{40} \mathrm{Ar} /{ }^{39} \mathrm{Ar}$ ages (sn) from ten geographically diverse localities, 26.90 $\pm 0.03 \mathrm{Ma}$ (Lipman and McIntosh, 2008)

Tndn Nonwelded to partly welded dacite - Uppermost Nelson Mountain Tuff, both within and locally outside the Cochetopa Park caldera (photo 18, CD-ROM). Yellowish-tan to gray, porous, vapor-phase-crystallized to glassy. Grades down into more welded dacitic Nelson Mountain Tuff (Tnd). Crystal rich; phenocrysts similar to welded dacite (Tnd). Mostly poorly exposed; especially well preserved on low ridge (photo 16B, CD-ROM) between Mexican Joe Gulch and Monchego Creek (CP). Thickness, 0-30 m

Tnd Welded silicic dacite and transitional rhyolite-dacite-Transitional rhyolite-silicic dacite welded zone $\left(67-72 \% \mathrm{SiO}_{2} ; 15-25 \% \mathrm{pl}>\mathrm{sn}, \mathrm{bi}>\mathrm{cpx}\right.$, qz). Characterized by less potassic sanidine compositions $\left(\mathrm{Or}_{64-67}\right)$ than mafic dacite of the dominant intracaldera facies (San Luis caldera complex). Forms brownish-gray main cliff-forming welded caprock of outflow Nelson Mountain Tuff, commonly with black vitrophyre (3-5 m) near base. Contains pumice lenses of both crystal-poor rhyolite and crystal-rich dacite. Grades downward into rhyolite (Tnr). Particularly thick and well exposed in narrows of Cochetopa Creek (photos 14, 16A, CD-ROM) along southwest caldera wall (CS). Thickness, 20-100 m

Tnr Welded to partly welded rhyolite - Light-gray and tan to light-reddish-brown welded ignimbrite $\left(71-74 \% \mathrm{SiO}_{2} ; 5-15 \% \mathrm{pl}>\mathrm{sn}>\mathrm{bi}>>\mathrm{cpx}\right)$. Dark-gray pumice fiamme, characterized by flattening ratios $<10: 1$, are commonly glassy and set in orange-brown devitrified matrix, forming colorful "halloween" rock (glassy black pumice lenses in devitrified red-brown matrix). Locally intensely zeolitized or argillically altered. Grades into less welded ignimbrite (Tnn). Exceptionally thick and well exposed along distal tongue of Nelson Mountain Tuff that flowed down the Cochetopa Creek graben into Cochetopa Park caldera (CS). Thickness, $0-50 \mathrm{~m}$

Tnn Nonwelded to partly welded rhyolite and silicic dacite - Gray porous pumiceous tuff containing common small angular fragments of andesitic lava. In most sections, originally glassy; now widely argillized or zeolitized. Some thick accumulations are vapor-phase crystallized, even where nonwelded. Commonly poorly exposed due to weak induration and to cover by talus from welded caprock (Tnd). Flow-unit partings, locally marked by thin crystal-rich surge beds and accretionary lapilli, are present in some well-exposed sections. Phenocrysts (typically 5-10\% pl, sn>bi) are similar to welded rhyolite (Tnr). Thickness, 10-200 m; greatest where accumulated along west margin of Cochetopa Park caldera south of Los Pinos Creek (CS)

\section{Rocks Erupted from the Cebolla Creek Caldera}

Eruption of the compositionally distinctive Cebolla Creek Tuff (photo 15, CD-ROM) caused subsidence of a large caldera within the San Luis complex, now largely concealed beneath the Nelson Mountain caldera and flanking postcollapse volcanoes, all lying southeast of the map area (Lipman, 2006)

Cebolla Creek Tuff-Distinctive compositionally uniform ignimbrite sheet of mafic dacite (photo 15, CD-ROM), characterized by abundant phenocrystic hornblende relative to augite and by lack of sanidine. Basal crystal- and lithic-rich surge beds, about $1 \mathrm{~m}$ thick, are well exposed at Wheeler Monument (Wheeler Geologic Area) just south of map area (Lipman, 2006). Previously mapped as part of the Nelson Mountain or Rat Creek Tuffs (Steven, 1967; Steven and Ratté, 1973; Steven and Bieniewski, 1977). Weakly welded deposits were widely eroded prior to eruption of Nelson Mountain Tuff, which directly overlies older units in many places within the general distribution area of the Cebolla Creek. Distinctive normal magnetic direction (Lipman, 2000, fig. 10). Weighted mean of four ${ }^{40} \mathrm{Ar} /{ }^{39} \mathrm{Ar}$ ages (hbl, bio), $27.10 \pm 0.0 .07 \mathrm{Ma}$, is anomalously slightly older than ages on sanidine from underlying Rat Creek Tuff

Tcc Weakly welded mafic dacite - Gray to light-brown, glassy to weakly vapor-phase-devitrified ignimbrite $\left(62-66 \% \mathrm{SiO}_{2} ; 25-40 \% \mathrm{pl}>>\mathrm{bi}, \mathrm{hbl}>>\mathrm{cpx}\right)$ typical of proximal outflow sections. Contains orange-brown to black pumice fragments ( $2-5 \mathrm{~cm}$ across) and abundant small (1-3 $\mathrm{cm}$ across) andesitic lithics. Exposed only as small erosional remnants in southwest map area. Thickness, $0-25 \mathrm{~m}$ 
The earliest ignimbrite sheet of the San Luis assemblage, the Rat Creek Tuff (photo 15, CD-ROM), is the smallest in volume, the most restricted in known areal extent, and the least understood. Evidence for the Rat Creek caldera (Lipman, 2000, p. 32-33) is also limited, because of cover by younger rocks

Rat Creek Tuff - Compositionally zoned ignimbrite sheet $\left(65-73 \% \mathrm{SiO}_{2}\right)$ of relatively modest volume, generally poorly exposed beneath Nelson Mountain Tuff. Within study area, only exposures are nonwelded to partly welded ignimbrite along southwest map margin (RC). Weakly welded deposits were widely eroded prior to eruption of Cebolla Creek Tuff, which directly overlies older units in many places within general distribution area of the Rat Creek Tuff. Weighted mean ${ }^{40} \mathrm{Ar} /{ }^{39} \mathrm{Ar}$ age (sn) from eight sample sites, 26.91 $\pm 0.02 \mathrm{Ma}$ (Lipman and McIntosh, 2008). Remanent magnetic polarity, normal

Trdn Weakly welded dacite - Gray tuff $\left(68-72 \% \mathrm{SiO}_{2}\right.$, silicified; $\left.25 \% \mathrm{pl}>\mathrm{sn}>\mathrm{bi}>>\mathrm{cpx}\right)$, characterized by vapor-phase matrix crystallization. Preserved as float, without real outcrops, in a few small areas along Los Pinos Creek in vicinity of McDonough Reservoir Number 2 (CS). No direct stratigraphic relation to the regional ignimbrite sheets erupted from the San Luis complex is preserved; correlation with Rat Creek based largely on lithology, isotopic age, and topographic position, far below caprock rim of Nelson Mountain Tuff south of Los Pinos Creek. ${ }^{40} \mathrm{Ar} /{ }^{39} \mathrm{Ar}$ age, $26.88 \pm 0.06 \mathrm{Ma}$. Thickness, 0-25 m

Trr Nonwelded rhyolite-Poorly exposed light-gray to yellow pumiceous tuff (70-73\% $\mathrm{SiO}_{2}$; 5-20\% pl, sn $>$ bi), commonly containing several percent centimeter-size fragments of andesitic to rhyolitic rocks. Typical sanidine composition is $\mathrm{Or}_{62} \mathrm{Ab}_{34} \mathrm{An}_{1.5} \mathrm{Cn}_{2.5}$ (Lipman and Weston, 2001). Glassy, ranging to zeolitic or argillically altered tuff. Grades upward into silicic dacite. Difficult to distinguish from rhyolitic Nelson Mountain Tuff (Tnn) in absence of intervening Cebolla Creek Tuff (Tcc). Exposed only on small hill near southwest corner of map area (RC); more widespread to the southwest. Thickness, 0-50 m

\section{ROCKS ERUPTED FROM SOUTH RIVER CALDERA}

South River caldera (fig. 2), resulting from eruption of the Wason Park Tuff, is defined by a steep caldera-wall unconformity that juxtaposes the caldera-filling South River Volcanics against flat-lying regional ignimbrites, now exhumed along the arcuate drainages of Red Mountain and Goose Creeks (Lipman, 2000, 2006)

Tw Wason Park Tuff-Distinctive regional ignimbrite sheet of crystal-rich rhyolite, locally grading upward into silicic dacite $\left(68-74 \% \mathrm{SiO}_{2} ; 10-30 \% \mathrm{pl}, \mathrm{sn}>>\mathrm{bi}>\mathrm{cpx}\right.$ ) (Ratté and Steven, 1967; Webber, 1988). Red-brown devitrified interior of cooling unit is characterized by white collapsed pumice lenses as much as $0.3 \mathrm{~m}$ long, consisting of intergrown alkali feldspar and tridymite. More phenocryst rich and alkalic than other San Juan rhyolitic ignimbrite sheets (Lipman and others, 1978); characterized by distinct tabular morpholology and sodic composition $\left(\mathrm{Or}_{55-60}\right)$ of sanidine phenocrysts. Preserved within map area only as small erosional remnants: along Still Creek within Los Pinos graben (RC), as a sinuous paleovalley fill (photo 12, CD-ROM ) at the mouth of Saguache canyon (LM), and as scattered small patches along Sheep Creek (TM); in these areas, 70.0-70.3\% $\mathrm{SiO}_{2}$. Weighted mean ${ }^{40} \mathrm{Ar} /{ }^{39} \mathrm{Ar}$ age (sn) for five sample sites, 27.38 $\pm 0.05 \mathrm{Ma}$ (Lipman and McIntosh, 2008). Remanent magnetic polarity, reverse (D $\left.174.7^{\circ}, \mathrm{I}-16.0^{\circ}\right)$ in Sheep Creek. Thickness within map area, $0-30 \mathrm{~m}$

\section{YOUNGER INTERMEDIATE-COMPOSITION LAVA FLOWS}

Mesa-capping mafic flows that are compositionally similar to slightly older lavas of the Huerto Andesite (Thu) and are difficult to distinguish reliably at some sites. These younger lavas constitute a compositional transition between the dominantly andesitic Oligocene volcanism and more basaltic lavas of the Miocene Hinsdale Formation (Lipman and others, 1970; Lipman and Mehnert, 1975). The lavas mapped here as the andesite of Mountain Lion Creek were previously mapped with the Hinsdale Formation (Tweto and others, 1976; Tweto, 1979), but Hinsdale-age rocks are now known only at a single locality in the 
northeastern San Juan Mountains (Houghland Hill (LG), just east of the map area; Lipman and McIntosh, 2008; table 2)

Tal Andesite of Mountain Lion Creek-Mesa-capping erosional remnants of fine-grained dark-gray lava flows of silicic olivine andesite (trachyandesite, $61-62 \% \mathrm{SiO}_{2}$ ) that overlie Carpenter Ridge Tuff (Tcr) at the head of Mountain Lion Creek and on Hat Mountain (GG, LM). Small sparse olivine phenocrysts, partly altered to rusty brown iddingsite, are typical. ${ }^{40} \mathrm{Ar}{ }^{39} \mathrm{Ar}$ ages on groundmass separates from three sites at head of Mountain Lion Creek group tightly at 27.46-27.51 Ma, suggesting emplacement just prior to eruption of the Wason Park Tuff (Tw) at $27.38 \pm 0.05 \mathrm{Ma}$ (Lipman and McIntosh, 2008). These flows appear to occupy a stratigraphic position similar to the lava flows of McClelland Mountain, as mapped within the southern Bachelor caldera $40 \mathrm{~km}$ to the southwest (Lipman, 2006). An additional site of olivine-bearing lava (Round Park-Hat Mountain area) yielded an older groundmass age $(27.81 \pm 0.16 \mathrm{Ma})$, but this flow may predate the Carpenter Ridge Tuff and thus be part of the Huerto Formation (Thu). Thickness $20-30 \mathrm{~m}$

\section{ROCKS ERUPTED FROM BACHELOR CALDERA}

The Bachelor caldera, entirely enclosed within central parts of La Garita caldera (fig. 2), was the source of the Carpenter Ridge Tuff (photos 10A, 11, CD-ROM), the second largest eruptive unit ( 1,000 $\mathrm{km}^{3}$ ) from the central caldera cluster. Thick intracaldera Carpenter Ridge Tuff, which consists dominantly of phenocryst-poor rhyolite, forms the host rocks for the economically important vein mineralization of the Creede district, within the central caldera cluster (Steven and Ratté, 1965; Lipman and others, 1989)

Carpenter Ridge Tuff-Widespread caldera-forming ignimbrite sheet, containing complex welding and compositional zonation $\left(67-74 \% \mathrm{SiO}_{2}\right)$, especially within Bachelor caldera. Volumetrically dominant rhyolite, containing $3-5 \%$ phenocrysts ( $\mathrm{pl}>\mathrm{sn}>\mathrm{bi}$ ), grades locally upward to silicic dacite (Mammoth Mountain Member) containing as much as 30\% phenocrysts in proximal sites. In comparison to other crystal-poor rhyolites within the map area, Carpenter Ridge sanidine compositions (typically $\mathrm{Or}_{64-66} \mathrm{Ab}_{31-33} \mathrm{An}_{1.2-1.5} \mathrm{Cn}_{1.0-1.2}$ ) are much more potassic than in Saguache Creek Tuff and less barium-rich than in the Sapinero Mesa Tuff. Weighted mean ${ }^{40} \mathrm{Ar} /{ }^{39} \mathrm{Ar}$ age (sn) for four sample sites, $27.55 \pm 0.05 \mathrm{Ma}$ (Lipman and McIntosh, 2008). Remanent magnetic polarity, reverse

Tcrn Nonwelded to partly welded tuff-Light-tan cavernous-weathering upper part of unit, locally forming distinctive vuggy knob outcrops of vapor-phase crystallized tuff. Sufficiently thick and distinctive to map separately where preserved along the downthrown side of the Lake Mountain fault zone (TM). Compositionally and mineralogically similar to the welded rhyolite (Tcr). Thickness, $0-15 \mathrm{~m}$

Tcr Welded rhyolite tuff-Dominantly phenocryst-poor tan rhyolite (Lipman and others, 1970; Whitney and others, 1988), widely characterized by black basal vitrophyre and conspicuous central lithophysal zone (photo 11, CD ROM). Forms widespread thin outflow sheet east of the Cochetopa Hills, where ash flows crossed the northeast rim of La Garita caldera and spread out in the headwaters of present-day Saguache Creek, and smaller erosional remnants elsewhere. Exceptionally thick (as much as $150 \mathrm{~m}$ ), where ponded along Los Pinos graben (RC), which subsided during formation of La Garita caldera. In this area, the Carpenter Ridge Tuff was initially confused with similar-appearing Sapinero Mesa Tuff (Tws) because of its low depositional level, topographically below exposures of the Fish Canyon Tuff on shoulders of the graben. Thickness, commonly $25-50 \mathrm{~m}$, as much as $150 \mathrm{~m}$ where ponded in Los Pinos graben

\section{ROCKS OF LA GARITA CALDERA CYCLE}

The enormous La Garita caldera (35 x $75 \mathrm{~km}$ across; $100 \mathrm{~km}$ if additional subsidence occurred in the Cochetopa Park area) and its eruptive products define the overall geometry of the central San Juan caldera cluster (fig. 2), all later calderas having formed within La Garita structure (Lipman, 2000, 2006). Its associated ignimbrite sheet, the enormous Fish Canyon Tuff, which consists of monotonously uniform phenocryst-rich dacite (at least 5,000 $\mathrm{km}^{3}$ ), has long been recognized as among the world's largest ignimbrite units (Lipman and others, 1970; Steven and Lipman, 1976; Bachmann and others, 2002) 
Huerto Andesite-Andesitic lava flows and volcaniclastic rocks (Larsen and Cross, 1956; Askren and others, 1991; Parat and others, 2005) form remnants of large shield volcanoes and flanking erosional debris, mainly within and adjacent to La Garita caldera. Thickest and best developed around and within southern parts of the caldera. Compositionally similar high-level lava flows within the map area (photo 13, CD-ROM) are correlated with the Huerto, on the basis of similar composition, stratigraphic position, and isotopic age

Thu Olivine-bearing andesite and hornblende-bearing andesite-dacite, undivided - Gray sparsely porphyritic olivine-bearing lavas and breccias, in places containing resorbed xenocrysts of quartz and feldspar, are overlain by Carpenter Ridge Tuff on east slope of Lake Mountain (LM). Lavas on Mount Lion, which are probably continuous with the Lake Mountain flows across Houselog Creek to the southeast, include a lower flow $\left(56.7 \% \mathrm{SiO}_{2}\right.$; ${ }^{40} \mathrm{Ar} /{ }^{39} \mathrm{Ar}$ age $\left.27.96 \pm 0.11 \mathrm{Ma}\right)$ and a xenocrystic upper flow $\left(61.9 \% \mathrm{SiO}_{2} ;{ }^{40} \mathrm{Ar} /{ }^{39} \mathrm{Ar}\right.$ age $27.64 \pm 0.12 \mathrm{Ma})$. Lavas characterized by phenocrystic hornblende $\left(60-63 \% \mathrm{SiO}_{2} ; 15-20 \%\right.$ $\mathrm{pl}>\mathrm{hbl}, \mathrm{cpx}$ ), directly overlie Fish Canyon Tuff on some hills in eastern map area, without intervening Carpenter Ridge Tuff. Particularly conspicuous is the thick flow on Trickle Mountain $\left(62.4 \% \mathrm{SiO}_{2} ;{ }^{40} \mathrm{Ar} /{ }^{39} \mathrm{Ar}\right.$ age on hornblende, $\left.27.92 \pm 0.19 \mathrm{Ma}\right)$. Some of these flows alternatively might be correlative with the andesite of Mountain Lion Creek (Tal) that yielded slightly old ages (not uncommon for hornblende and groundmass ages), or even constitute early-erupted lavas of the Hinsdale Formation. Maximum thickness, $100 \mathrm{~m}$ on Trickle Mountain, $50 \mathrm{~m}$ on Lake Mountain

Fish Canyon Tuff-A single large cooling unit of nonwelded to densely welded gray to lightbrown ignimbrite of compositionally uniform silicic dacite $\left(66-68 \% \mathrm{SiO}_{2} ; 40-50 \% \mathrm{pl}>>\mathrm{sn}\right.$, qtz, bi $>\mathrm{hbl}$ ), preserved as much as $100 \mathrm{~km}$ beyond rims of La Garita caldera. Characterized by simple welding zonation except in thick proximal sections, where compound welding is locally developed. Pumice fragments are obscure in many exposures of devitrified tuff, and lithic fragments typically are sparse. Densely welded tuff is massive (photo 10, CD-ROM), but upper parts commonly have slabby jointing parallel to obscure compaction foliation. Rare dark pumice lenses, which lack large phenocrysts and resemble crystal-poor rhyolite in the field, contain abundant finely milled crystal fragments and are compositionally identical to the more common pumice fragments of crystal-rich dacite. Sparse resorbed pinkish quartz, accessory sphene, and hornblende without augite are distinctive phenocrysts (Lipman, 1975; Whitney and Stormer, 1985). Sanidine phenocrysts (typically $\left.\mathrm{Or}_{72-74} \mathrm{Ab}_{23-24} \mathrm{An}_{1} \mathrm{Cn}_{1.5}\right)$ are relatively potassic and conspicuously zoned, with barium $(\mathrm{Cn})$ varying 1-4 mol percent (Lipman and others, 1997; Bachman and others, 2002). ${ }^{40} \mathrm{Ar}{ }^{39} \mathrm{Ar}$ age, 28.02 Ma (currently accepted as geochronologic standard; Renne and others, 1998). Magnetic polarity, normal. Maximum thickness within map area, $100 \mathrm{~m}$

Tfcb Fault-scarp breccia, with clasts of Fish Canyon Tuff-Narrow zones of brecciated Fish Canyon Tuff, developed locally along intricate system of normal faults where the Los Pinos graben merges with the west margin of Cochetopa Park caldera (CS). Interpreted as having formed concurrently with eruption of the Fish Canyon Tuff and subsidence of La Garita caldera, because faults of the Los Pinos graben predate emplacement of the Carpenter Ridge Tuff (Tcr). May provide evidence for early subsidence (or at least volcano-tectonic processes) within the Cochetopa Park area during the Fish Canyon eruptions. Difficult to distinguish in some outcrops from younger landslide breccia with clasts of Fish Canyon Tuff (Tpbf) associated with late subsidence of the Cochetopa Park caldera during eruption of Nelson Mountain Tuff; some associated faults may have become reactivated during this later subsidence

TfC Widespread welded outflow ignimbrite sheet - Light-gray variably welded tuff, commonly forming massive rounded outcrops with columnar and sheet cooling joints. Continuously outcropping and exceptionally thick (to $300 \mathrm{~m}$ ) where ponded within southeast side of North Pass caldera. Similarly thick and banked abruptly against andesitic lavas of the Conejos Formation southeast of McDonough Park (RC), a feature which may record early subsidence in the Cochetopa Park area during eruption of the Fish Canyon Tuff. More discontinuously preserved and variable in thickness along northern parts of map area because of deposition along broad north-trending paleovalleys. Thickness, $0-300 \mathrm{~m}$

Tfen Nonwelded to partly welded tuff-Poorly exposed weakly indurated lower parts of distal ignimbrite sheet. Sufficiently thick and widespread to map separately only along lower Razor Creek and in Parlin Flats area (HG). Thickness, 0-25 m 


\section{OLDER TUFFS RELATED TO WESTERN SAN JUAN CALDERAS}

Distal facies of several regional ignimbrite sheets erupted from western San Juan sources (Lipman and others, 1973; Steven and Lipman, 1976; Bove and others, 2001) are exposed discontinuously north of the central caldera cluster (Olson, 1974; Steven and Hail, 1989). These include three lithologically similar phenocryst-poor rhyolite ignimbrites (Blue Mesa, Dillon Mesa, and Sapinero Mesa Tuffs). Only the Sapinero Mesa Tuff is present within the map area

Sapinero Mesa Tuff-Nonwelded to partly welded gray-brown to red-brown rhyolitic ignimbrite sheet $\left(72-74 \% \mathrm{SiO}_{2} ; 3-5 \% \mathrm{pl}>\mathrm{sn}>\right.$ bi), locally containing black basal vitrophyre, erupted from the composite Uncompahgre-San Juan caldera (Steven and Lipman, 1976). Typically thin and discontinuously preserved. Where thickest (west of map area), contains a well-developed central lithophysal zone (as much as 10-20 m thick), similar to that in the Carpenter Ridge Tuff. Most widespread of the three phenocryst-poor western ignimbrite sheets; only one present within map area. Difficult to distinguish from Carpenter Ridge Tuff (Tcr), except by stratigraphic position relative to Fish Canyon Tuff and by locally distinct welding and crystallization textures. Distinguished in field by presence of sparse biotite phenocrysts from otherwise similar-appearing Saguache Creek Tuff (Tsc); also contains more potassic and barium-rich sanidine (average, $\mathrm{Or}_{61} \mathrm{Ab}_{33} \mathrm{An}_{2} \mathrm{Cn}_{4}$ ). Partly welded distal outcrops distinguished in field from similar-appearing tuff of Big Dry Gulch (Tbg) by presence of sanidine. ${ }^{40} \mathrm{Ar} /{ }^{39} \mathrm{Ar}$ age (sn), $28.20 \pm 0.06 \mathrm{Ma}$ in Houselog Creek (LG). Magnetic polarity, reverse: D $116.1^{\circ}, \mathrm{I}-65.4^{\circ}$ in Houselog Creek. Maximum thickness, $25 \mathrm{~m}$

Twsb Fault-scarp breccia, with clasts of Sapinero Mesa Tuff-Narrow zone of breccia along south normal fault of the Los Pinos graben, where this fault crosses Blue Creek (CS). Clasts of densely welded tuff occupy zone 5-10 m wide, bounded to south by altered Conejos-age intrusive porphyry and to north by unaltered Fish Canyon Tuff

Tws Welded outflow tuff sheet-Red-brown to tan welded tuff, containing small flattened pumice lapilli. Best developed east of Monument Creek (SH) and north of upper Los Pinos Creek (RC, CS). Thickness, 0-75 m

Twsn Nonwelded to partly welded distal tuff-Weakly indurated gray to tan distal tuff, commonly vapor-phase crystallized, that is discontinuously preserved and exposed mostly as slopemantling clasts in northwestern areas along Gunnison valley (HG) and along Right Creek (SH), in southwest map area (GC), and east of the present map area in Houselog Creek (LG) Thickness, $0-25 \mathrm{~m}$

\section{CONEJOS FORMATION, UPPER UNITS}

Locally erupted lavas and tuffs that overlie the Saguache Creek Tuff and other units of the North Pass caldera cycle. These diverse rocks are stratigraphically equivalent to upper parts of the Conejos Formation farther west and south in the San Juan region, where early Oligocene ignimbrite sheets that provide regional stratigraphic marker horizons are absent. An unusual cluster of thick rhyolitic-dacitic lava flows and domes, about $6 \mathrm{~km}$ across in preserved areal extent and centered in Barret Creek (WB), may record a failed caldera system (Lipman and McIntosh, 2008). Several small areas of basaltic to andesitic lava flows and a thin dacitic ignimbrite, preserved within and adjacent to the North Pass caldera, are as much as $2 \mathrm{~m}$.y. younger than the main eruptive units of this caldera. These rocks may represent prolonged late activity of the caldera cycle or, alternatively, may be local expressions of continuing regional flux of intermediate-composition eruptions (upper units of the Conejos Formation), unrelated to any specific ignimbrite-caldera cycle

Tcuv Upper volcaniclastic rocks of the Conejos Formation - Crudely bedded to well-bedded conglomerates, sandstones, and mudflow breccias, containing rounded clasts of dark andesite and dacite in lighter-gray sandy matrix. Overlie Saguache Creek Tuff (Tsc) along canyon of Cochetopa Creek (IR). Stratigraphically equivalent to andesitic conglomerate in the volcanics of Cochetopa Hills (Tsa), volcaniclastic rocks on the andesite of Lone Tree Mesa (Tlav), and lithologically similar conglomerates (too thin to show at map scale) interleaved with the Saguache Creek and Sapinero Mesa Tuffs along Saguache Creek in the eastern map area. Thickness, as much as $50 \mathrm{~m}$ 
Rhyolite of Barret Creek-Flows and domes of aphyric to porphyritic rhyolite and silicic dacite clustered in upper Barret Creek and along the divide toward Razor Creek to the south (WB). Overall thickness, as much as $400 \mathrm{~m}$

Tbfc Coarsely porphyritic rhyolite - Massive light-gray flows and domes of low-silica rhyolite and dacite $\left(68-75 \% \mathrm{SiO}_{2}\right)$ containing $20-30 \%$ phenocrysts of plagioclase, sanidine, and biotite. Basal black vitrophyre zones are locally as much as $25 \mathrm{~m}$ thick; carapace breccia is preserved in places. ${ }^{40} \mathrm{Ar} /{ }^{39} \mathrm{Ar}$ ages (sn), 29.63-29.85 Ma (samples from three flows). Thickness of individual flows, $0-300 \mathrm{~m}$

Tbfa Aphyric to sparsely porphyritic rhyolite - Light-gray to tan flow-layered rhyolite (71-75\% $\mathrm{SiO}_{2}$ ) typically containing less than $5 \%$ phenocrysts of plagioclase and biotite. Devitrified and glassy rocks are interleaved along steeply dipping ramp structures at tops of some flows. ${ }^{40} \mathrm{Ar} /{ }^{39} \mathrm{Ar}$ age (sn), $29.79 \pm 0.05 \mathrm{Ma}$ (flow on Green Mountain, WB). Thickness of individual flows, $0-250 \mathrm{~m}$

Basalt of point Benny - Flow of fine-grained dark-gray silicic basalt $\left(52.0 \% \mathrm{SiO}_{2}\right)$ and an associated eroded vent dike and aggutinated vent scoria at point Benny (named hill top, NP), centrally located within the North Pass caldera (photo 4, CD-ROM). Basalt is finely olivinephyric and contains widely distributed sparse xenocrysts of quartz and feldspar, derived from disaggregated fragments of Precambrian granite. Despite the xenocrystic component, this flow is the most mafic Oligocene volcanic unit yet documented from anywhere in the San Juan region. Weighted mean ${ }^{40} \mathrm{Ar} /{ }^{39} \mathrm{Ar}$ age of $30.22 \pm 0.10 \mathrm{Ma}$ for groundmass determinations on five samples (Lipman and McIntosh, 2008) is consistent with stratigraphic position beneath Fish Canyon Tuff, also with eruption nearly concurrent with the late andesite of hill 9519 that ponded against the east wall of the North Pass caldera

Tbpf Lava flow-Several small erosional remnants of a single large basaltic lava flow. Fish Canyon Tuff fills paleovalleys eroded into the basalt, in places cropping out at levels below that of the lava flow. Thickness, $0-30 \mathrm{~m}$

Tbpv Cone scoria-Aggutinated dark-gray to red-brown scoria at point Benny, interpreted as marking eroded cone from which basalt flow erupted. Thickness, $0-50 \mathrm{~m}$

Tbpi Vent dike and lava pond-Basaltic dike and massive lava at crest of point Benny are interpreted as eroded vent deposits. The near-vertical dike, $10-20 \mathrm{~m}$ wide, cuts upward through scoria wall rock and flares into a broader mass of dense basalt interpreted as remnants of lava lake within a crater

Andesite of Lone Tree Gulch (Saguache valley) - Several andesitic lava flows and associated volcaniclastic rocks (photo 9, CD-ROM) lie between the tuff of Big Dry Gulch (Tbg) and overlying Fish Canyon Tuff (Tfc) along the axis of paleo-Saguache Creek, on the southeast flank of Trickle Mountain and adjacent areas (TM-LM boundary). A whole-rock ${ }^{40} \mathrm{Ar} /{ }^{39} \mathrm{Ar}$ age of $30.21 \pm 0.17 \mathrm{Ma}$ links this andesite closely to the slightly older andesite flows of hill 9519 that are ponded against the east wall of the North Pass caldera, but the location of these flows well to the east suggests that they represent continued regional flux of intermediatecomposition volcanism unrelated to any caldera cycle

Tla Lava flows - Dark-gray flows of sparsely porphyritic vesicular andesite-dacite $\left(59 \% \mathrm{SiO}_{2}\right)$. Most individual flows are 5-10 m thick; maximum total thickness, $50 \mathrm{~m}$

Tlav Volcaniclastic rocks - Thin locally exposed lenses of reworked crudely bedded to well-bedded laharic conglomerates, sandstones, and mudflow breccias, containing clasts of dark andesite in light-gray sandy matrix. Mainly preserved along mesa northwest of Trickle Mountain. Reliably distinguishable from older volcaniclastic units, such as distal debris-flow deposits of Buffalo Pass Campground (Tdc) or volcanics of Cochetopa Hills (Tsa), only where separated by interlayered tuff of Big Dry Gulch (Tbg). Thickness, 0-15 m

Tbg Tuff of Big Dry Gulch - Nonwelded to partly welded gray-brown to red-brown dacitic ignimbrite $\left(67 \% \mathrm{SiO}_{2} ; 3-5 \% \mathrm{pl}>\mathrm{bi}>>\mathrm{cpx}\right)$, locally containing black basal vitrophyre. Erupted from unknown source. Forms a distinctive local marker unit above the Saguache Creek Tuff (Tsc) and laharic debris-flow deposit with clasts of Luders Creek Tuff ( $\mathrm{Tdb}$ ) and below the andesite of Lone Tree Gulch (Tla). Distinguished from similar-appearing Sapinero Mesa Tuff (Tws) by absence of sanidine, presence of sparse clinopyroxene phenocrysts and more abundant biotite, isotopic age, and magnetic direction. Because this distinction was recognized only late during fieldwork, assignment of some isolated small exposures may be erroneous. ${ }^{40} \mathrm{Ar}{ }^{\beta 9} \mathrm{Ar}$ age (biotite plateau), $30.47 \pm 0.08 \mathrm{Ma}$; magnetic direction, D $175.8^{\circ}, \mathrm{I}-37.6^{\circ}$. Maximum thickness, $20 \mathrm{~m}$ 
Tab Andesite of Big Dry Gulch - Dark-gray crystal-poor andesite as chaotic breccia and some possibly intact lava flows. Forms rugged outcrops of massive monolithologic breccia in upper reaches of Big Dry Gulch (LM). Much of unit appears to have been emplaced as landslide material; parts may be primary eruptive deposits, perhaps on proximal flank of source eruptive edifice. Formed paleotopographic highs at time of eruption of the Fish Canyon Tuff. Age and emplacement relations are uncertain relative to the tuff of Big Dry Gulch (Tbg) or andesite of Lone Tree Gulch (Tla); these two andesite units may represent proximal and more distal portions of a single eruptive sequence. Thickness, $0-50 \mathrm{~m}$

Debris-flow deposits of Buffalo Pass Campground-Variable fragmented poorly sorted deposit, derived largely from Luders Creek Tuff exposed in the vicinity of the present-day Continental Divide. Clast size decreases, clast roundness increases, and proportion of Luders Creek Tuff decreases relative to andesitic clasts with distance eastward from source region, as transport in debris flows gives way to more fluidized mudflow and stream transport. Generation process, 2 m.y. after main phases of the North Pass caldera cycle, is uncertain; perhaps emplaced in response to some late structural events near concealed source for eruption of Luders Creek Tuff

Tdc Distal conglomerate - Thin locally exposed lenses of reworked crudely bedded to well-bedded stream conglomerate and sandstones, containing dominant clasts of dark andesite and sparse clasts derived from the Luders Creek Tuff in light-gray sandy matrix. In southeastern part of map area (LM) and farther to east. Reliably distinguishable from younger volcaniclastic rocks, such as those in the andesite of Lone Tree Gulch (Tlav), only where separated by interlayered tuff of Big Dry Gulch (Tbg). Thickness, $0-15 \mathrm{~m}$

$\mathrm{Tdb} \quad$ Mesobreccia and conglomerate - Poorly sorted mixed clasts dominated by light-tan rhyolite and dark-gray dacite fragments derived from the Luders Creek Tuff; clasts of andesitic lava increase in relative abundance eastward. In western parts of the unit, angular slabs of darkgray dacitic Luders Creek Tuff are as much as $10 \mathrm{~m}$ across; in places, distinction is difficult between essentially in-place Luders Creek Tuff and material that has suffered significant transport in secondary debris flows. Thickness, $0-75 \mathrm{~m}$

Tdbm Megabreccia blocks - Dense masses of healed breccia derived from Luders Creek Tuff (Tld) and perhaps some dacitic lava (dacite of East Pass Creek, Tnpd), forming rugged knobs within the fine-grained debris-flow deposit over a small area near the Buffalo Pass Campground (photo $8 \mathrm{C}, \mathrm{CD}-\mathrm{ROM}$ ). Coherent knobs defining individual megablocks within the debris-flow deposit are as much as $25 \mathrm{~m}$ across. Brecciation within the knobs is so severe that the original character of the rocks is widely obscured (photo $8 \mathrm{D}, \mathrm{CD}-\mathrm{ROM}$ ); the brecciation and rehealing predated debris-flow transport of the megablocks to their present sites Andesite of hill 9519 - Thick flow of porphyritic hornblende andesite on hill 9519 and overlying aphyric andesite, banked against the east wall of the North Pass caldera at Sheep Creek (TM), constitute late-erupted fill within this caldera (photo 6, CD-ROM)

Taha Aphyric andesite - A single dense dark-gray lava flow $\left(57 \% \mathrm{SiO}_{2}\right)$ that lacks phenocrysts. Conglomeratic sedimentary debris, including clasts of Precambrian rocks, is locally present as float, raveling out from between the aphyric flow and underlying hornblende andesite (Tahh). Age, 29.98 $\pm 0.31 \mathrm{Ma}$ (whole rock); thickness, 0-20 m

Tahh Hornblende andesite - Massive thick dark-gray lava flow of porphyritic andesite $(20 \% \mathrm{pl}$, hbl). Where banked along the caldera wall, the massive hornblende andesite $\left(58 \% \mathrm{SiO}_{2}\right)$ and its inclined columnar-jointed margin somewhat resemble an intrusive body. Emplacement as a ponded lava flow is indicated by presence of elliptical vesicles, even within the most massive interior of the unit, and by continuity with subhorizontal eastern parts of the flow that directly overlie Saguache Creek Tuff where the lava overflowed the caldera wall. ${ }^{40} \mathrm{Ar} /{ }^{39} \mathrm{Ar}$ age, $30.41 \pm 0.79 \mathrm{Ma}$ (hbl). Thickness, 0-250 m

\section{CALDERA-RELATED ROCKS PREDATING THE WESTERN AND CENTRAL CALDERA CLUSTERS}

Several ignimbrites, exposed widely in the map area, were erupted from northeastern sources and predate the large ignimbrite sheets erupted from the central and western caldera clusters. These ignimbrites include the Saguache Creek and Luders Creek Tuffs erupted from the North Pass caldera at 32.2 Ma, as well as the Bonanza Tuff erupted from the Bonanza caldera at 33.2 Ma. They have ages older than much 
of the precaldera Conejos Formation that has been dated farther south and west in the San Juan region, yet they overlie andesitic-dacitic lavas that are compositionally similar to the younger Conejos rocks to the south. Where interfingering relations with datable ignimbrites are absent, lower and upper components of the overall Conejos assemblage cannot readily be separated. The northeastern ignimbrite units also define an age and geographic progression toward caldera-related volcanism of early Oligocene age in central Colorado (McIntosh and Chapin, 2004; Lipman, 2007)

\section{North Pass Caldera Cycle}

The newly recognized North Pass caldera, source of the recently identified Saguache Creek Tuff (Lipman and Calvert, 2003; Lipman and McIntosh, 2008), is nearly concealed beneath caldera-filling lavas and tuffs, erupted from the same general area (volcanics of Cochetopa Hills, Luders Creek Tuff), and younger ignimbrites from central San Juan sources (Fish Canyon and Carpenter Ridge Tuffs). All rocks of this caldera cycle, including the precursor tuff of Spanish Creek, appear to have erupted during a brief interval at about $32 \mathrm{Ma}$. Thus, in age and geographic location, this caldera defines a transition between older ignimbrite calderas aligned north-south along the Sawatch Range, of which Bonanza at $33 \mathrm{Ma}$ is the youngest and most southerly, and younger caldera systems located more centrally within the San Juan volcanic field

Luders Creek Tuff-Compositionally zoned cooling unit, changing upward from weakly welded light-tan rhyolite ignimbrite to densely welded dark-gray dacite (named by Lipman and McIntosh, 2008). Previously described as the "tuff of Luders Creek" (Lipman, 2006). Exposed only in small areas along the Continental Divide (northeastern SP, NP), where it is underlain by the caldera-filling volcanics of Cochetopa Hills and overlain by Fish Canyon Tuff. Similar in appearance, phenocryst mineralogy, and chemical zoning to outflow Nelson Mountain Tuff, with which the Luders Creek Tuff had been correlated previously (Steven and Lipman, 1976, fig. 24). Presence of laharic debris, derived from Luders Creek Tuff, below the Fish Canyon Tuff and above the Saguache Creek Tuff, initially demonstrated that this tuff is a separate older ignimbrite, now confirmed by isotopic ages. Limited preserved distribution of this unit suggests probable eruption from within the North Pass caldera, beneath subsequent cover by Fish Canyon and Carpenter Ridge Tuffs, or from within the area of the younger Cochetopa Park caldera. Maximum thickness within map area, $75 \mathrm{~m}$

Tld Welded dacite - Upper dark-gray welded zone (66-68\% $\left.\mathrm{SiO}_{2} ; 20-30 \% \mathrm{pl}>\mathrm{sn}, \mathrm{bi}>\mathrm{cpx}\right)$. Sanidine phenocrysts $\left(\mathrm{Or}_{56} \mathrm{Ab}_{42} \mathrm{An}_{2.0} \mathrm{Cn}_{0.3}\right.$ ) commonly contain Ba-rich rims (to $\mathrm{Or}_{56} \mathrm{Ab}_{35}$ $\mathrm{An}_{2.6} \mathrm{Cn}_{6.4}$ ). Exposed only as small slumped and severely rotated outcrops of brownish-gray caprock, which closely resembles upper parts of outflow Nelson Mountain Tuff (Tnd). Contains pumice lenses of both crystal-poor rhyolite and crystal-rich dacite. Grades downward into rhyolite (TIr). Distributed widely as clasts in debris-flow deposits of Buffalo Peak Campground. ${ }^{40} \mathrm{Ar} /{ }^{39} \mathrm{Ar}$ ages (sn), $32.15 \pm 0.06 \mathrm{Ma}$ from outcrops at the head of Luders Creek, $32.15 \pm 0.05 \mathrm{Ma}$ from clast in laharic debris-flow deposit (Tdb). Thickness, $10-20 \mathrm{~m}$

TIr Nonwelded to partly welded rhyolite - Lower zone of weakly welded light-tan tuff ( $72-73 \%$ $\mathrm{SiO}_{2} ; 5-10 \% \mathrm{pl}, \mathrm{sn}>>$ bi), exposed only as float on hill slopes beneath welded dacite (Tld). Sanidine phenocrysts are more sodic and homogeneous $\left(\mathrm{Or}_{49} \mathrm{Ab}_{49} \mathrm{An}_{1.7} \mathrm{Cn}_{0.1}\right)$ than in overlying later-erupted dacite. ${ }^{40} \mathrm{Ar} /{ }^{39} \mathrm{Ar}$ ages (sn), 32.15 $\pm 0.06 \mathrm{Ma}$ and $32.22 \pm 0.05 \mathrm{Ma}$. Thickness, $0-75 \mathrm{~m}$

\section{Volcanics of Cochetopa Hills}

North Pass caldera-fill deposits. A diverse assemblage of volcaniclastic deposits and lava flows that accumulated largely within the North Pass caldera, soon after subsidence associated with eruption of the Saguache Creek Tuff (Tsc). Dacitic lava flows (Tnpd) constitute volumetric bulk of unit (photo 8, CD-ROM)

Volcaniclastic deposits - Sandstone, bedded tuff, and conglomerate that are interlayered with and underlie the lava flows within and near the North Pass caldera

Tst Bedded rhyolitic tuff-White to light-tan tuff deposited in shallow-lake or low-energy stream environments. Preserved discontinuously along west caldera margin, where overlies older caldera-fill units (volcanics of Cochetopa Hills). Deposits resemble tuffaceous sedimentary fill (Tct) of the young Cochetopa Park caldera to the west, but their higher topographic level and location along margins of the North Pass caldera suggest that they are most plausibly 
interpreted as late sedimentation during filling of this caldera, probably in conjunction with eruption of rhyolitic lava flows (Tnpr) or the Luders Creek Tuff. Preserved thickness, 0-30 m

Dacitic conglomerate - Reworked crudely bedded conglomerate and mudflow breccia, containing clasts of light-gray porphyritic dacite (Tnpd) in weakly indurated lighter-gray sandy matrix. Exposed only in small areas near the Continental Divide near the southwest caldera margin (NP). Typically present as loose cobbles on subdued slopes. Thickness, 0-20 m

Tsa Andesitic conglomerate - Mostly reworked crudely bedded to well-bedded conglomerate, sandstone, and mudflow breccia, containing clasts of dark andesite and sparse dacite in weakly indurated lighter-gray sandy matrix. Exposed mainly in upper Luders Creek and its tributaries (NP). Outcrops are rare; unit typically present as loose cobbles on subdued slopes. Closely resembles volcaniclastic sediments of Conejos Formation (Tcv) and difficult to distinguish in many localities. Critical to identification as a younger volcaniclastic assemblage is presence of rare clasts of Saguache Creek Tuff (Tsc), most prominently on north side of Luders Creek (NP) just west of overlying Fish Canyon Tuff. Sparse clasts of crystalrich dacitic ignimbrite (Tbc, or Tts?) are also present locally in unit along ridge between Luders and Cantonment Creeks. Beyond margins of the North Pass caldera, unit is difficult to distinguish from some younger volcaniclastic rocks of upper parts of the Conejos Formation (Tdc, Tlav), where intervening units are absent

Postcaldera lava flows - Andesitic, dacitic, and rhyolitic flows that filled the North Pass caldera and widely overflowed its rims

Tnpd Dacite of East Pass Creek-Massive flows of gray to tan crystal-rich dacite (62-66\% $\mathrm{SiO}_{2}$; $20-30 \% \mathrm{pl}>\mathrm{bi}>\mathrm{cpx}$ ). Dominant exposed fill of the North Pass caldera. Thickest and most widespread accumulations are north of North Pass, where multiple thick flows are marked by basal vitrophyre and upper carapace-breccia zones. ${ }^{40} \mathrm{Ar} /{ }^{39} \mathrm{Ar}$ age (bi) from three flows within main body of this unit, 32.07-32.31 Ma. Individual flows are as thick as $200 \mathrm{~m}$; total thickness, $0-500 \mathrm{~m}$

Tnpr Rhyolite of Taylor Canyon - Scattered lava domes of phenocryst-poor gray to light-tan rhyolite $\left(74-76 \% \mathrm{SiO}_{2} ; 1-5 \% \mathrm{sn}, \mathrm{pl}\right)$. Flow layering, glassy carapace breccia, and ramp structures near upper surfaces are typical. At least one flow, exposed along west caldera wall in Corduroy Creek (NP), is mineralogically and chemically distinctive, similar to the Saguache Creek Tuff (Tsc) in lacking biotite phenocrysts and containing elevated incompatible traceelement contents. ${ }^{40} \mathrm{Ar} /{ }^{39} \mathrm{Ar}$ age (sn) on flow in Corduroy Creek, 32.15 $\pm 0.10 \mathrm{Ma}$. Exposed thickness, $0-150 \mathrm{~m}$

Tnpa Andesite, undivided — Local flows of dark-gray phenocryst-poor andesite (1-10\% pl, cpx). Mainly exposed along west caldera margin. Thickness $0-50 \mathrm{~m}$

Saguache Creek Tuff-Crystal-poor rhyolite ignimbrite (named by Lipman and McIntosh, 2008), distributed discontinuously over much of the map area (photo 5, CD-ROM). Similar in appearance and phenocryst content to proximal Sapinero Mesa Tuff (Tws), to which this unit had been previously assigned in adjacent areas (Bruns and others, 1971; Steven and Lipman, 1976, fig. 10; Olson, 1988). More recently described as the "tuff of Saguache Creek" by Lipman and Calvert (2003) and Lipman (2006). The Saguache Creek lacks biotite, has more sodic low-barium sanidine $\left(\mathrm{Or}_{50-51.5} \mathrm{Ab}_{45-47} \mathrm{An}_{2.6-2.8} \mathrm{Cn}_{0.5}\right)$, has different trace-element bulk compositions, and is more densely welded than the distal Sapinero Mesa within the map area. Also resembles, but different in similar ways, the upper rhyolite of underlying Bonanza Tuff that is exposed just east of the map area (LG: Bruns and others, 1971; Varga and Smith, 1984). Weighted mean ${ }^{40} \mathrm{Ar} /{ }^{39} \mathrm{Ar}$ age (sn) for Saguache Creek Tuff is $32.25 \pm 0.05 \mathrm{Ma}$ for six determinations from separate localities, significantly younger than the Bonanza Tuff (33.2 Ma; McIntosh and Chapin, 2004). Eruption of the Saguache Creek Tuff from North Pass caldera is supported by the preserved distribution of this unit, semisymmetrically around the North Pass area where not hidden by younger rocks (to the south and west), and by stratigraphic relations with postcaldera lavas. Magnetic polarity, reverse; D $168^{\circ}, \mathrm{I}-55^{\circ}$ in Saguache and Salaya Creeks. Thickness, $0-75 \mathrm{~m}$

Tscl Landslide breccia of hill 9943-Weakly indurated monolithologic breccia consisting solely of clasts of welded Saguache Creek Tuff. In addition to exposure on hill 9943 (head of Muddy Creek, ST), exposures of similar breccia occupy paleovalleys along East Sheep Creek (TM) and Long Gulch (HG). In Long Gulch, Fish Canyon Tuff laps onto the slide breccia, demonstrating its Oligocene age. Thickness, $0-40 \mathrm{~m}$ 
Tscc Densely welded crystal-rich rhyolite - Local upper zone of densely welded dark-gray tuff $\left(73.5 \% \mathrm{SiO}_{2} ; 15-20 \% \mathrm{pl}, \mathrm{sn}\right)$, exposed as small outcrops along Mexican Joe Gulch (northern SP) and on hill 10,076 (ST). Thickness, 0-15 m

Tsc Nonwelded to densely welded crystal-poor rhyolite - Variably welded light-tan to red-brown tuff $\left(74-76 \% \mathrm{SiO}_{2} ; 5-10 \% \mathrm{pl}, \mathrm{sn}\right)$. Locally grades up into more densely welded crystal-rich rhyolite (Tscc). Thickness, $0-50 \mathrm{~m}$

Tscn Nonwelded crystal-poor rhyolite - Light-gray upper part of ignimbrite sheet (photo 5B, CD-ROM) that is locally sufficiently thick and distinctive to be mapped as separate zones. Thickness, $0-35 \mathrm{~m}$

Tbt Bedded tuff-White to light-gray weakly indurated bedded tuff and sandstone (photo 5C, CD-ROM). Includes reworked fluviatile and lake-bed deposits, as well as thin ash-fall and nonwelded ignimbrite deposits. Exposed below Saguache Creek Tuff mainly in basin (Alkali Spring) west of Trickle Mountain (TM) and locally farther east along Saguache Creek. Thickness, $0-75 \mathrm{~m}$

Tuff of Spanish Creek-Crystal-rich rhyolite ignimbrite exposed locally beneath the Saguache Creek Tuff (Tsc) and interpreted as possible precursor eruption of the North Pass cycle, based on distribution and similar ages

Tts Welded tuff-Nonwelded gray to densely welded pale-brown crystal-rich rhyolite ignimbrite (73-75\% $\mathrm{SiO}_{2} ; 20-30 \% \mathrm{pl}$, sn, qtz, bi, trace hbl), preserved only in small areas on north side of Spanish Creek (NP) and north of Samora Creek (WB). Thick vitrophyre and rheomorphic flow layering where banked against steep paleotopography north of Samora Creek. Clasts of this unit are present in breccias along the North Pass caldera margin, along the mouth of Pine Creek and in roadcuts along Colorado Highway 114 (NP). Broadly resembles Fish Canyon Tuff in welding appearance, crystallization textures, and phenocryst assemblage, but has modestly lower total phenocryst content, more abundant quartz and sanidine, and more silicic bulk composition. ${ }^{40} \mathrm{Ar} /{ }^{39} \mathrm{Ar}$ ages (sn) in Spanish Creek, 32.48 \pm 0.05 $\mathrm{Ma}$ (vitrophyre) and 32.55 $\pm 0.05 \mathrm{Ma}$ (overlying devitrified tuff); north of Samora Creek, $32.40 \pm 0.05 \mathrm{Ma}$; and in collapse breccia along the northwest margin of North Pass caldera, 32. $45 \pm 0.05 \mathrm{Ma}$

Ttsn Nonwelded tuff-White to light-gray nonwelded crystal-rich ignimbrite (15-25\% pl, sn, qtz, bi), exposed locally beneath Saguache Creek Tuff on both sides of Saguache Creek near mouth of Big Dry Gulch (TM-LM boundary). ${ }^{40} \mathrm{Ar} /{ }^{\beta 9} \mathrm{Ar}$ age (sn), $32.49 \pm 0.6 \mathrm{Ma}$ on nonwelded tuff in lower Squaw Creek (LM). Tentatively correlated with welded ignimbrite in Spanish Creek, based on similar stratigraphic position, phenocryst mineralogy, and age. Thickness, 0-25 m

\section{Intrusions of Uncertain Affinity}

Fine-grained intrusive rocks, mostly dikes, lacking definitive features of areal distribution or petrology that permit confident correlation with a stratigraphically constrained volcanic sequence. Many of these are probably associated with Conejos-age volcanoes, but some are likely younger

Tia Andesite - Dark-gray dikes and other small intrusive bodies, typically containing small phenocrysts $(\mathrm{pl}>\mathrm{cpx}, \mathrm{hbl})$

Tid Dacite - Gray dikes and larger intrusive bodies, typically phenocryst rich, containing $\mathrm{pl}>\mathrm{bi}>\mathrm{hbl}$, cpx. One large dacite intrusion with a near-horizontal roof is well exposed at the head of Long Branch (SM). An intrusion at Cochetopa Pass (NP) that is truncated by the southwest margin of North Pass caldera yielded an ${ }^{40} \mathrm{Ar} /{ }^{39} \mathrm{Ar}$ age (sn) of $32.19 \pm 0.13 \mathrm{Ma}$; its emplacement may have been a precursor event of the North Pass caldera cycle. Another probable dacite intrusion in upper Razor Creek (RD) may alternatively be a thick near-vent flow/ dome associated with the rhyolite of Barret Creek

Tir Rhyolite - Light-gray to tan dikes, containing $\mathrm{pl}>\mathrm{bi}$, qtz

\section{Bonanza Caldera Cycle}

The southwest rim of the Bonanza caldera, source of the 33-Ma Bonanza Tuff, lies only about $5 \mathrm{~km}$ northeast of the map area (BZ, KM; fig. 4), and rocks associated with this eruptive center constitute major volcanic accumulations in the eastern map area. Bonanza is the southernmost and youngest of a chain of four ignimbrite caldera centers (Grizzly Peak, Princeton, Aetna, Bonanza) aligned north-south along the 
Sawatch Range that marks the west shoulder of the present-day Rio Grande rift zone in central Colorado (fig. 1)

Postcaldera lavas and related rocks - A thick sequence of dominantly andesitic lava flows that accumulated within the Bonanza caldera after subsidence and spread across proximal outflow Bonanza Tuff (Varga and Smith, 1984). Preserved mainly east of the map area. Without intervening Bonanza Tuff, this lava assemblage is difficult to distinguish from underlying rocks of the Conejos Formation, and some of the Conejos in central and western parts of map area include units equivalent to the upper andesite of the Bonanza cycle

Tba Upper andesite - Dark-gray to brown andesite and dacite, containing sparse small phenocrysts (pl, hbl, cpx). Within map area, preserved only as a small erosional remnant of andesite that overlies Bonanza Tuff on a ridge spur east of junction, forks of Long Branch (SM ). Thickness, $25 \mathrm{~m}$

Bonanza Tuff - Outflow ignimbrite sheet displaying complexly gradational welding and compositional zonation: from densely welded lower rhyolite and dacite (photo 2, CD-ROM), upward into less welded rhyolite, and, locally, an upper welded dacite. Upper rhyolite and dacite are exposed only east of the map area. Weighted mean age for 14 samples throughout regional extent, 33.2 Ma (McIntosh and Chapin, 2004; W. McIntosh, written commun., 2007)

Tbd Lower dacite - Mainly densely welded dark-gray to brown crystal-rich dacite welded tuff (63-66\% $\mathrm{SiO}_{2} ; 25-35 \% \mathrm{pl}>>\mathrm{bi}$, sn, cpx, qtz). Preserved as discontinuous erosional remnants of paleovalley fills along east margin of map area; more widespread farther east. Sanidine

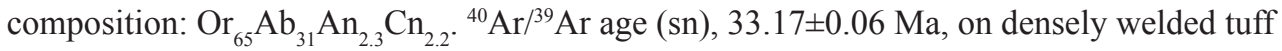
that may be a megabreccia block along the northwest margin of North Pass caldera (NP, along Hwy 114). Thickness, $0-100 \mathrm{~m}$

Tbrl Lower rhyolite, densely welded-Red-brown crystal-poor rhyolite $\left(72-74 \% \mathrm{SiO}_{2} ; 5-10 \%\right.$ $\mathrm{sn}>>\mathrm{pl}>>\mathrm{bi}, \mathrm{hbl}$ ). Compared to other crystal-poor biotite-bearing rhyolite tuffs in the map area (Tws, Tcr), rhyolitic Bonanza Tuff has a much higher sanidine:plagioclase phenocryst ratio and contains small phenocrysts of hornblende in addition to biotite. Sanidine composition $\mathrm{Or}_{53} \mathrm{Ab}_{45} \mathrm{An}_{1.9} \mathrm{Cn}_{0.03}$. Within map area, only a single small area of outcrops on ridge spur east of junction at forks of Long Branch (northern SM). Locally thick in lower part of intracaldera fill (BZ); probably correlates with widespread outflow rhyolitic Bonanza Tuff to east (Gribbles Park Tuff of McIntosh and Chapin, 2004). ${ }^{40} \mathrm{Ar} /{ }^{39} \mathrm{Ar}$ age (sn), $33.19 \pm 0.05 \mathrm{Ma}$ in Long Branch. Thickness, about $25 \mathrm{~m}$

\section{VOLCANIC ROCKS PREDATING BONANZA CALDERA}

\section{Conejos Formation, Lower Units}

Thick accumulations of dominantly andesite and dacite as lava flows and proximal breccias that were erupted from central volcanoes, surrounded by voluminous aprons of volcaniclastic debris (photo 3A, CD-ROM) emplaced as mudflow and stream-fan deposits (Lipman, 1975; Colucci and others, 1991). These intermediate-composition lavas, breccias, and associated intrusions, which underlie caldera-related ignimbrites throughout the San Juan region, constitute the volumetric bulk of the volcanic deposits. Subsequently deeply eroded, the early eruptive deposits are now discontinuously exposed as surviving topographic highs along margins of the ignimbrite calderas. In distal areas, locally difficult to distinguish from younger suites of compositionally similar intermediate-composition lavas, which were emplaced concurrently with the ignimbrite eruptions. Compositional subunits among Conejos lavas have been divided in varying detail, depending on degree of local diversity, quality of exposures, and mapping scale. In the northeastern San Juan Mountains proximal lavas tend to become more silicic upward, with biotite-bearing dacite and low-silica rhyolite especially abundant on the northeast side of Cochetopa Park caldera. Much of this unit, which underlies the Bonanza Tuff (33.2 Ma) in the eastern map area, is older than widespread Conejos rocks to the south and west, which appear to have erupted largely in the interval 33-30 Ma. In the vicinity of the Bonanza caldera, just east of the map area, lower parts of the Conejos Formation that are overlain by the Bonanza Tuff have long been designated the "Rawley Andesite" (Burbank, 1932; Varga and Smith, 1984), but compositionally similar pre-Bonanza lavas erupted from multiple centers are the dominant volume of the Conejos Formation across much of the map area. Maximum exposed thickness, about $800 \mathrm{~m}$ along the 
north flanks of Middle Baldy (WB) or Sawtooth Mountain (ST); sections as much as $2.3 \mathrm{~km}$ thick have been penetrated by petroleum exploration drilling just east of the map area (Gries, 1985; Brister and Gries, 1994)

Tci Intermediate-composition granitoid intrusions - Fine-grained equigranular to porphyritic monzonite and granodiorite $(\mathrm{pl}>>\mathrm{cpx}>>\mathrm{bi})$, grading irregularly into porphyritic andesite. Occurs as small stocks, dikes, and rare sills representing the intrusive cores of Conejos volcanoes. An intrusion exposed in Alkali Creek (ST) probably marks the core of a large stratovolcano; present-day topographic highs of Sawtooth Mountain and Razor Creek Dome represent the northwest and northeast flanks of this volcano, as indicated by primary dips of lavas and other proximal deposits along both sides of Cochetopa valley. A dike along Hwy $114(\mathrm{RD})$ probably associated with this center has a ${ }^{40} \mathrm{Ar} /{ }^{39} \mathrm{Ar}$ age $(\mathrm{hbl})$ of $34.81 \pm 0.16 \mathrm{Ma}$. The large elongate Needle Creek intrusion, a texturally diverse composite body including sill- and dike-like components (photo 3B, CD-ROM), probably represents the core of another large edifice, for which West Baldy constitutes the eroded southern flank. Hornblende ${ }^{40} \mathrm{Ar} /{ }^{39} \mathrm{Ar}$ determinations from three sites in this intrusion (WB) yielded ages of $34.28-34.42$ Ma

Lava flows and proximal breccias - Flows and flow breccias of aphanitic to porphyritic lava from many volcanic centers, some of which probably lie within subsided areas of calderas (photos 20, 27, CD-ROM). Primary dips preserved on flanks of volcanoes are as steep as $30^{\circ}$

Tca Andesite - Finely porphyritic to aphanitic dark-gray lava flows and breccia $\left(55-61 \% \mathrm{SiO}_{2}\right.$; $5-15 \% \mathrm{pl}>\mathrm{cpx}, \mathrm{hbl}$ ), constituting the most voluminous Conejos Formation lithology. Individual flows are 5-40 m thick; multiple-flow accumulations are as much as several hundred meters thick on volcano flanks

Tcsa Andesite scoria-Reddish-brown agglutinated scoria, marking a largely buried vent exposed on hill 10,943 (CS), along ridge crest $2 \mathrm{~km}$ south of Agency Peak. Similar unmapped scoria is present locally elsewhere in the Conejos Formation. Thickness, $50 \mathrm{~m}$

Tcap Plagioclase andesite-Distinctive porphyritic dark-gray lavas $\left(56-60 \% \mathrm{SiO}_{2} ; 15-30 \%\right.$ $\mathrm{pl} \gg>\mathrm{cpx}$ ), characterized by tabular phenocrysts of plagioclase as much as $1 \mathrm{~cm}$ across

Tcd Dacite - Gray porphyritic flow-layered lava and breccia, characterized by light color and conspicuous biotite phenocrysts $\left(62-68 \% \mathrm{SiO}_{2} ; 20-30 \% \mathrm{pl}>>\right.$ bi, cpx, hbl). Massive, locally with flow layering or basal vitrophyre. Widely distributed, but much less abundant than andesites of Conejos Formation. Commonly high in the Conejos lava sequence. In proximity to the North Pass caldera, locally difficult to distinguish reliably from younger dacite of the caldera fill (Tnpd). At the south boundary of the map area, near Carnero Pass, a petrologically unusual dacite flow, containing large sanidine phenocrysts (to $2 \mathrm{~cm}$ ), yielded an ${ }^{40} \mathrm{Ar} /{ }^{39} \mathrm{Ar}$ age (sn) of $32.71 \pm 0.10 \mathrm{Ma}$. In Needle Creek (WB), a thick sanidine-bearing dacite flow low in the Conejos lava sequence has ${ }^{40} \mathrm{Ar} /{ }^{39} \mathrm{Ar}$ ages (sn, two sites) of $34.10 \pm 0.05$ and $33.98 \pm 0.08 \mathrm{Ma}$, similar to the granodiorite intrusion (Tci) that cuts the lava sequence in this area. Farther west, a dacite flow, which caps Sawtooth Mountain (ST) and is interpreted to be an upper part of a volcanic construct that may postdate the Saguache Creek Tuff, has an

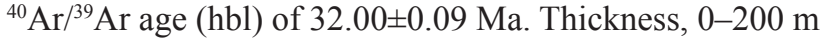

Tcfr Rhyolite - Light-gray to tan flow-layered lava and breccia $\left(70-76 \% \mathrm{SiO}_{2} ; 3-5 \% \mathrm{pl}>\mathrm{bi}\right)$. Rare crystal-rich flows (to $15-20 \%$ phenocrysts) contain sparse high-K sanidine $\left(\mathrm{Or}_{69-71} \mathrm{Ab}_{26-27} \mathrm{An}_{0.5-1.0} \mathrm{Cn}_{2-3}\right)$. Especially common high in the Conejos Formation northeast of North Pass caldera (SM-TM boundary). Overlain by Bonanza Tuff, so distinctly older than petrologically similar crystal-poor rhyolite of the Barret Creek assemblage (Tbfa). These flows may represent initial silicic magmatism precursor to explosive ignimbrite eruptions from Bonanza center. A large rhyolite dome along Archuleta Creek near the southwest rim of North Pass caldera (CP), which has an ${ }^{40} \mathrm{Ar} /{ }^{39} \mathrm{Ar}$ age (sn) of $32.17 \pm 0.06 \mathrm{Ma}$, may represent precursor volcanism of the North Pass caldera cycle. An isolated sanidine-bearing rhyolite flow, near the entry to Cochetopa Canyon (ST) yielded an age of $37.13 \pm 0.09 \mathrm{Ma}$. This is the oldest silicic volcanic rock thus far dated from the San Juan region, similar in age to the voluminous Wall Mountain Tuff (Twm) erupted farther north in the SRMVF. Thickness, 0-125 m

TcV Volcaniclastic rocks-Mostly reworked crudely bedded to well-bedded conglomerates, sandstones, and mudflow breccias, containing clasts of dark andesite and dacite in light-gray sandy matrix (photo $3 \mathrm{~A}, \mathrm{CD}-\mathrm{ROM}$ ). Primary dips are typically $<5^{\circ}$. Mainly distal deposits 
on lower slopes of volcanic constructs; most abundant in the northern map area. Volumetrically less abundant, relative to proximal lavas, than in preserved Conejos sequence farther west and south in the San Juan region. Maximum thickness, about $200 \mathrm{~m}$ on east flank of Sawtooth Mountain (ST)

Rhyolitic tuff-Small local units of nonwelded phenocryst-poor rhyolitic tuff (75-76\% $\mathrm{SiO}_{2}$; $1-3 \% \mathrm{pl}>>$ bi) are poorly exposed near base of the Conejos Formation in the northern map area and stratigraphically higher along the septum of Conejos rocks exposed between North Pass and Cochetopa Park calderas. Some of the rhyolitic tuff is areally associated with compositionally similar rhyolitic lava flows of Conejos age, but eruptive sources have not been identified

Tct Tan to light-gray rhyolitic tuff and tuffaceous sandstone-Weakly indurated and poorly exposed tuff, variably altered to clays and zeolites. Locally thick along inner east wall of Cochetopa Park caldera (CP-NP boundary) and in the northeastern map area, especially in vicinity of the Needle Creek intrusion (north WB). Maximum thickness, $\sim 125 \mathrm{~m}$ north of Archuleta Creek (east CP)

Tcht Pink tuff of Home Gulch-Distinctive nonwelded ignimbrite of nearly aphyric rhyolite exposed low in the Conejos Formation along north margin of Cochetopa Park caldera. Small angular fragments of andesite and sparse Precambrian rocks are conspicuous; in Home Gulch (RD), locally are as large as $0.5 \mathrm{~m}$. Sparse small crystal fragments are mostly xenocrysts. Overlain at mouth of Alkali Creek (ST) by rhyolitic lava flow with sanidine age of $37.13 \pm 0.09$ Ma. Maximum thickness, $100 \mathrm{~m}$

Tev Early volcaniclastic sedimentary deposits - Conglomerates and sandstones containing fragments of intermediate-composition lavas and some Precambrian clasts. Includes coarse boulder conglomerate (clasts to $1 \mathrm{~m}$ ) west of Long Branch (SM). Records erosion from paleohills of Precambrian rocks early during Tertiary volcanism. Thickness, $0-20 \mathrm{~m}$

\section{EARLY IGNIMBRITES ERUPTED FROM SAWATCH RANGE CALDERAS}

Tbc Badger Creek Tuff-Distinctive gray partly to densely welded ignimbrite (67-69\% $\mathrm{SiO}_{2}$; $25-35 \% \mathrm{pl}>\mathrm{bi},>\mathrm{sn}, \mathrm{hb}, \mathrm{qtz})$. Present as slump masses in northeast corner of map area (SS); larger outcrop areas are present farther east along Marshall Creek (PP). Resembles Fish Canyon Tuff ( $\mathrm{Tfc}$ ) in lithology, mineral composition (for example, potassic sanidine: $\mathrm{Or}_{72} \mathrm{Ab}_{25} \mathrm{An}_{0.8} \mathrm{Cn}_{2.8}$ ), and rock chemistry, but erupted at $34.1 \mathrm{Ma}$ (McIntosh and Chapin, 2004) from the Mount Aetna caldera in the Sawatch Range (fig. 1). Thickness, 0-40 m

Twm Wall Mountain Tuff-Distinctive red-brown densely welded ignimbrite (photo 1, CD-ROM), product of the oldest large pyroclastic eruption in the Southern Rocky Mountains. Crystalrich rhyolite $\left(70-75 \% \mathrm{SiO}_{2} ; 20-30 \% \mathrm{sn}, \mathrm{pl}>\right.$ bi), characterized by large tabular phenocrysts of unaltered sanidine (typically $\mathrm{Or}_{61-62} \mathrm{Ab}_{34-35} \mathrm{An}_{2-3} \mathrm{Cn}_{1-3}$ ) and widely argillized plagioclase. Large lenses of compacted pumices (to $0.5 \mathrm{~m}$ ) commonly weather as cavities that resemble gas cavities (photo 1B, CD-ROM); widespread rheomorphic flowage of this unit (Chapin and Lowell, 1979) produces ramp structures in upper parts, with dips of compaction foliation locally approaching vertical (photo $1 \mathrm{~A}, \mathrm{CD}-\mathrm{ROM}$ ). Unit is widespread in central Colorado, reaching the High Plains between Denver and Colorado Springs, but had not previously been recognized west of the Rio Grande rift zone. In the northern map area, scattered erosional remnants are preserved in paleovalleys, resting directly on pre-Tertiary rocks; some of these had previously been variably mapped as Sapinero Mesa Tuff (Olson and Steven, 1976a) and Cochetopa Park Tuff (Olson and others, 1975). Erupted in the Sawatch Range 70-90 km to the northeast, probably from a caldera that was above the Mount Princeton batholith (Johnson and others, 1989; Lipman, 2007). ${ }^{40} \mathrm{Ar}{ }^{39} \mathrm{Ar}$ age (sn) in

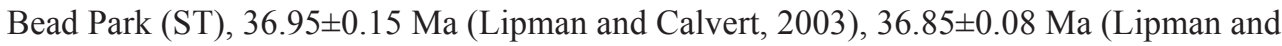
McIntosh, 2008). Magnetic polarity, normal (as determined in Bead Creek, with portable fluxgate magnetometer). Thickness, $0-100 \mathrm{~m}$

\section{PREVOLCANIC ROCKS}

Mesozoic and rare Tertiary sedimentary deposits are widely distributed along the north boundary of the map area, beneath the Oligocene volcanic rocks of the San Juan region; large areas are concealed 
beneath widespread landslide deposits. The sedimentary sequence is underlain by Proterozic granite that intrudes metasedimentary and metavolcanic rocks

\section{MESOZOIC SEDIMENTARY ROCKS}

$\mathrm{Km} \quad$ Mancos Shale (Cretaceous) - Dark-gray to brown silty shale, too poorly indurated to make good exposures. Widely covered by landslide deposits. Preserved thickness, 0-200 m

Kd Dakota Sandstone (Cretaceous) - Light-gray to brown sandstone, with interbeds of friable siltstone and platy sandstone in upper part. Medium to coarse grained, locally crossbedded, well indurated. Thickness, $15-70 \mathrm{~m}$

Jm Morrison Formation (Jurassic) — Varigated green-gray to red-brown mudstone, siltstone, andplaty sandstone. Thickness, 25-100 m

Jj Junction Creek Sandstone (Jurassic) - Light-yellow to gray eolian quartzose sandstone; fineto medium grained, locally crossbedded, and silicified. Thickness, 10-50 m

\section{PALEOZOIC SEDIMENTARY ROCKS}

Pzl Paleozoic limestone (lower Paleozoic) - Gray to tan limestone and limey sandstone, exposed as concentrated boulders in small area west of lower Long Branch (SS). Similar rocks crop out more widely along Marshall Creek, just northeast of map area (Olson, 1983)

\section{PRECAMBRIAN ROCKS}

p€g Granitic intrusive rocks, undivided-Medium-grained pink to tan, locally weakly gneissic intrusive rock of Proterozoic age (photo 28, CD-ROM), containing about $30-40 \%$ microcline, $25 \%$ plagioclase, $20-30 \%$ quartz, and 3-10\% biotite. Mapped and described in more detail by Olson (1976a,b, 1988). Published ages are in range 1,676-1,713 Ma (Bickford and others, 1988)

p€m Metamorphic rocks, undivided-Interlayered metasedimentary and metavolcanic rocks of Proterozoic age, including foliated schist, phyllite, quartzite, metabasalt, and metarhyolite. Mapped and described in more detail by Olson (1988) and maps referenced

\section{REFERENCES CITED}

Askren, D.R., 1992, Origin of andesites interlayered with large-volume ash-flow tuffs in the western United States: University of Georgia, Ph.D. dissertation, $281 \mathrm{p}$.

Askren, D.R., Whitney, J.A., and Roden, M.F., 1991, Petrology and geochemistry of the Huerto Andesite, San Juan volcanic field, Colorado: Contributions to Mineralogy and Petrology, v. 107, p. 373-386.

Askren, D.R., Whitney, J.A., and Roden, M.F., 1991, Petrology and geochemistry of the Huerto Andesite, San Juan volcanic field, Colorado: Contributions to Mineralogy and Petrology, v. 107, p. 373-386.

Bachmann, O., 1997, The Alboroto Group, San Juan volcanic field, Colorado-Insights into large caldera cycles: Switzerland, Universite de Geneve, Diplome.

Bachmann, Olivier, Dungan, M.A., Lipman, P.W., 2002, The Fish Canyon magma body, San Juan volcanic field, Colorado-Rejuvenation and eruption of an upper crustal batholithic magma chamber: Journal of Petrology, v. 43, p. 1469-1503.

Bachmann, O., Oberli, F., Dungan, M.A., and Fischer, H., 2007, ${ }^{40} \mathrm{Ar} /{ }^{39} \mathrm{Ar}$ and $\mathrm{U}-\mathrm{Pb}$ dating of the Fish Canyon magmatic system, San Juan volcanic field, Colorado-Evidence of an extended crystallization history: Chemical Geology, v. 236, p. 134-166.

Bailey, R.A., Dalrymple, G..B., and Lanphere, M.A., 1976, Volcanism, structure, and geochronology of Long Valley caldera, Mono County, California: Journal of Geophysical Research, v. 81, p. 725-744.

Bethke, P.M., and Hay, R.L., eds., 2000, Ancient Lake CreedeIts volcano-tectonic setting, history of sedimentation, and relation to mineralization in the Creede mining district: Geological Society of America Special Paper 346, 332 p.

Bickford, M.E., Shuster, R.D., Boardman, S.J., 1989, U-Pb geochronology of the Proterozoic volcano-plutonic terrane in the Gunnison and Salida areas, Colorado: Geological Society of America Special Paper 235, p. 33-48.

Bove, D.J., Hon, Ken, Budding, K.E., Slack, J.F., Snee, L.W., and Yeoman, R.A., 2001, Geochronology and geology of late Oligocene through Miocene volcanism and mineralization in the western San Juan Mountains, Colorado: U.S. Geological Survey Professional Paper $1642,30 \mathrm{p}$.

Brister, B.S., and Gries, R.R., 1994, Depth and geometry of the northern Rio Grande rift in the San Luis Basin, 
south-central Colorado, in Keller, G.R., and Cather, S.M., eds., Basins of the Rio Grande Rift-Structure, stratigraphy, and tectonic setting: Geological Society of America Special Paper 291, p. 39-58.

Bruns, D.L., Epis, R.C., Weimer, R.G., and Steven T.A., 1971, Stratigraphic relations between Bonanza center and adjacent parts of the San Juan volcanic field, south-central Colorado: New Mexico Geological Society Guidebook 22, p. 183-190.

Burbank, W., 1932, Geology and ore deposits of the Bonanza mining district: U.S. Geological Survey Professional Paper $169,166 \mathrm{p}$.

Chapin, C.E., and Lowell, G.R., 1979, Primary and secondary flow structures in ash-flow tuffs of the Gribbles Run paleovalley, central Colorado: Geological Society of America Special Paper 180, p. 137-153.

Colucci, M.T., Dungan, M.T., Ferguson, K.M., Lipman, P.W., and Moorbath, Steven, 1991, Precaldera lavas of the southeast San Juan volcanic field—Parent magmas and crustal interactions: Journal of Geophysical Research, v. 96, p. 13412-13434.

Cross, Whitman, and Larsen, E.S., Jr., 1935, A brief review of the geology of the San Juan region of southwestern Colorado: U.S. Geological Survey Bulletin 843, 138 p.

Diehl, J.F., Beck, M.E., and Lipman, P.W., 1974, Palaeomagnetism and magnetic-polarity zonation in some Oligocene volcanic rocks of the San Juan Mountains, southwestern Colorado: Geophysical Journal of the Royal Astronomical Society, v. 37, p. 323-332.

Dorais, M.J., Whitney, J.A., and Stormer, J.C., Jr, 1991, Mineralogical constraints on the petrogenesis of trachytic inclusions, Carpenter Ridge Tuff, central San Juan volcanic field, Colorado: Contributions to Mineralogy and Petrology, v. 107, p. 219-230.

Drenth, B.J., and Keller, G.R., 2004, New gravity and magnetic maps of the San Juan volcanic field, southwestern Colorado [abs.]: Eos, Transactions of the American Geophysical Union, v. 85, p. F623.

Dungan, M.A., Lipman P.W., Colucci, M.T., Ferguson, K.M., and Balsley, S.D., 1989, Southeastern (Platoro) caldera complex, in Chapin, C.E., and Zidek, J., eds., Field excursions to volcanic terranes in the western United States, Volume I-Southern Rocky Mountain region: New Mexico Bureau of Mines and Mineral Resources Memoir 46, p. 305-329.

Epis, R.C., and Chapin, C.E., 1974, Stratigraphic nomenclature of the Thirtynine Mile volcanic field: U.S. Geological Survey Bulletin 1395-C, 23 pp.

Fridrich, C.J., DeWitt, E., Bryant, B., Richard, S., and Smith, R.P., 1998, Geologic map of the Collegiate Peaks Wilderness area and the Grizzly Peak caldera, Sawatch Range, central Colorado: U.S. Geological Survey Miscellaneous Investigations Map I-2565.

Gravley, D.M., Wilson, C.J.N., Leonard, G.S., and Cole, J.W., 2007, Double trouble - Paired ignimbrite eruptions and collateral subsidence in the Taupo Volcanic Zone, New Zealand: Geological Society of America Bulletin, v. 119, p.
$18-30$.

Gregory, K.M., and McIntosh, W.C., 1996, Paleoclimate and paleo-elevation of the Oligocene Pitch-Pinnacle flora, Sawatch Range, Colorado: Geological Society of America Bulletin, v. 108, p. 545-561.

Gries, R.R., 1985, San Juan sag - Cretaceous rocks in a volcanic-covered basin, south-central Colorado: The Mountain Geologist, v. 22, p. 167-179.

Hedlund, D.C., and Olson J.C., 1974, Geologic map of the Iris NW quadrangle, Gunnison and Saguache Counties, Colorado: U.S. Geological Survey Geologic Quadrangle Map GQ-1134, scale 1:24,000.

Hildreth, W., and Fierstein, J., 2000, Katmai volcanic cluster and the great eruption of 1912: Geological Society of America Bulletin, v. 112, p. 1594-1620.

Hon, K., and Lipman, P.W., 1989, Western San Juan caldera complex, in Chapin, C.E., and Zidek, J., eds., Field excursions to volcanic terranes in the western United States-Volume I, Southern Rocky Mountain region: New Mexico Bureau of Mines and Mineral Resources Memoir 46, p. 350-378.

John, D.A., 1995, Tilted middle Tertiary ash-flow calderas and subjacent granitic plutons, southern Stillwater Range, Nevada - Cross sections of an Oligocene igneous center: Geological Society of America Bulletin, v. 107, p. 180-200.

John, D.A., Henry, C. and Colgan, J., 2008, Tectonic and magmatic evolution of the Caetano Caldera, north-central Nevada - A tilted mid-Tertiary eruptive center and source of the Caetano Tuff: Geosphere, v. 4, p. 75-106.

Johnson, C.M., Shannon, J.R., Fridrich, C.J., 1989, Roots of ignimbrite calderas-Batholithic plutonism, volcanism, and mineralization in the Southern Rocky Mountains, Colorado and New Mexico: New Mexico Bureau of Mines and Mineral Resources Memoir 46, p. 275-302.

Lanphere, M.A., 1988, High-resolution ${ }^{40} \mathrm{Ar} /{ }^{39} \mathrm{Ar}$ chronology of Oligocene volcanic rocks, San Juan Mountains, Colorado: Geochimica et Cosmochimica Acta, v. 52, p. 1425-1434.

Lanphere, M.A., 2000, Duration of sedimentation of the Creede Formation from ${ }^{40} \mathrm{Ar} /{ }^{39} \mathrm{Ar}$ ages, in Bethke, P.M., and Hay, R.L., eds., Ancient Lake Creede-Its volcanotectonic setting, history of sedimentation, and relation to mineralization in the Creede mining district: Geological Society of America Special Paper 346, p. 71-76.

Larsen, E.S., and Cross, Whitman, 1956, Geology and petrology of the San Juan region, southwestern Colorado: U.S. Geological Survey Professional Paper 258, 303 p.

Le Bas, M.J., Le Maitre, R.W., Streckeisen, A., and Zanetin, B., 1986, A chemical classification of volcanic rocks based on the total alkali-silica diagram: Journal of Petrology, v. 27, p. 745-750.

Lichte, F.E., Golightly, D.W., and Lamothe, P.J., 1987, Inductively coupled plasma-atomic emission spectrometry, in Baedecker, P.A., ed., Methods for geochemical analysis: U.S. Geological Survey Bulletin 1770, p. B1-B10.

Lipman, P.W., 1964, Chemical comparison of glassy and crystalline volcanic rocks: U.S. Geological Survey Bulletin 
1201-D, 24 p.

Lipman, P.W., 1975, Evolution of the Platoro caldera complex and related volcanic rocks, southeastern San Juan Mountains, Colorado: U.S. Geological Survey Professional Paper 852, $128 \mathrm{p}$.

Lipman, P.W., 1976, Geologic map of the Lake City caldera, western San Juan Mountains, Colorado: U.S. Geological Survey Miscellaneous Investigations Series Map I-962.

Lipman, P.W., 1984, The roots of ignimbrite calderasWindows into the tops of granitic batholiths: Journal of Geophysical Research, v. 89, p. 8801-8841.

Lipman, P.W., 1987, Rare-earth-element compositions of Cenozoic volcanic rocks in the southern Rocky Mountains and adjacent areas: U.S. Geological Survey Bulletin 1668, $23 \mathrm{p}$.

Lipman, P.W., 1993, Geologic map of the Tucson Mountains caldera, Arizona: U.S. Geological Survey Miscellaneous Investigations Map I-2205, scale 1:48,000.

Lipman, P.W., 1988, Evolution of silicic magma in the upper crust - The mid-Tertiary Latir volcanic field and its cogenetic granitic batholith, northern New Mexico, USA: Transactions of the Royal Society of Edinburgh, v. 79, p. 265-288.

Lipman, P.W., 1997, Subsidence of ignimbrite calderasRelation to caldera size and magma-chamber geometry: Bulletin of Volcanology, v. 59, p. 198-218.

Lipman, P.W., 2000, The central San Juan caldera clusterRegional geologic framework, in Bethke, P.M., and Hay, R.L., eds., Ancient Lake Creede-Its volcanotectonic setting, history of sedimentation, and relation to mineralization in the Creede mining district: Geological Society of America Special Paper 346, p. 9-70.

Lipman, P.W., 2004, Chemical analyses of Tertiary volcanic rocks, central San Juan caldera complex, southwestern Colorado: U.S. Geological Survey Open-File Report 2004-1194.

Lipman, P.W., 2006, Geologic map of the central San Juan caldera complex, Southwestern Colorado: U.S. Geological Survey Geologic Investigations Series I-2799, scale $1: 50,000$.

Lipman, P.W., 2007, Incremental assembly and prolonged consolidation of Cordilleran magma chambers-Evidence from the Southern Rocky Mountain Volcanic Field: Geosphere, v. 3, p. 42-70.

Lipman, P.W., and Calvert, A., 2003, Southward migration of mid-Tertiary volcanism-Relations in the Cochetopa area, north-central San Juan Mountains, Colorado [abs.]: Geological Society of America Abstracts with Programs, v. 35, no 5, p. 14.

Lipman, P.W., Doe, B.R., Hedge, C.E., and Steven, T.A., 1978, Petrologic evolution of the San Juan volcanic field, southwestern Colorado- $\mathrm{Pb}$ and $\mathrm{Sr}$ isotope evidence: Geological Society of America Bulletin, v. 89, p. 59-82.

Lipman, P.W., Dungan, M.A., and Bachmann, Olivier, 1997, Eruption of granophyric granite from a large ignimbrite magma chamber-Implications for emplacement of the Fish Canyon Tuff and collapse of the La Garita caldera,
San Juan Mountains, Colorado: Geology, v. 25, p. 915-918.

Lipman, P.W., Dungan, M.A., Brown, L.D., and Deino, Allen, 1996, Recurrent eruption and subsidence at the Platoro caldera complex, southeastern San Juan volcanic field, Colorado-New tales from old tuffs: Geological Society of America Bulletin, v. 108, p. 1039-1055.

Lipman, P.W., and McIntosh, W.C., 2008, Eruptive and noneruptive calderas, northeastern San Juan Mountains, Colorado-Where did the ignimbrites come from?: Geological Society of America Bulletin, v. 120, p. 771-795.

Lipman, P.W., and Mehnert, H.H., 1975, Late Cenozoic basaltic volcanism and development of the Rio Grande depression in the southern Rocky Mountains: Geological Society of America Memoir 144, p. 119-153.

Lipman, P.W., Sawyer, D.A., and Hon, K., 1989, Central San Juan caldera cluster: New Mexico Bureau of Mines and Mineral Resources Memoir 46, p. 330-350.

Lipman, P.W., Steven, T.A., Luedke, R.G., and Burbank, W.S., 1973, Revised history of the San Juan Uncompahgre, Silverton, and Lake City calderas in the Western San Juan Mountains: U.S. Geological Survey Journal of Research, v. 1, no. 6, p. 627-642.

Lipman, P.W., Steven, T.A., and Mehnert, H.H., 1970, Volcanic history of the San Juan Mountains, Colorado, as indicated by potassium-argon dating: Geological Society of America Bulletin, v. 81, p. 2327-2352.

Lipman, P.W., and Weston, P.E., 2001, Phenocryst compositions of late ignimbrites from the central San Juan caldera cluster-Results from Creede drill-hole samples and implications for regional stratigraphy, in Bethke, P.M., ed., Preliminary scientific results of the Creede caldera continental scientific drilling program: U.S. Geological Survey Open-File Report 94-260B, 43 p.

McIntosh, W.C., and Chapin, C.E., 2004, Geochronology of the central Colorado volcanic field: New Mexico Bureau of Geology and Mineral Resources Bulletin 160, p. 205-238.

O'Leary, W.J., 1981, The magmatic paragenesis of the Fish Canyon ash-flow tuff, central San Juan Mountains, Colorado: University of Georgia, M.S. thesis, 103 p.

Olson, J.C., 1974, Geologic map of the Rudolph Hill quadrangle, Gunnison, Hinsdale, and Saguache Counties, Colorado: U.S. Geological Survey Geologic Quadrangle Map GQ-1177, scale 1:24,000.

Olson, J.C., 1976a, Geologic map of the Houston Gulch quadrangle, Gunnison and Saguache Counties, Colorado: U.S. Geological Survey Geologic Quadrangle Map GQ-1287, scale 1:24,000.

Olson, J.C., 1976b, Geologic map of the Iris quadrangle, Gunnison and Saguache Counties, Colorado: U.S. Geological Survey Quadrangle Map GQ-1286, scale $1: 24,000$.

Olson, J.C., 1983, Geologic and structural maps and sections of the Marshall Pass Mining District, Saguache, Gunnison, and Chafee Counties, Colorado: U.S. Geological Survey Miscellaneous Investigations Series Map I-1425, scale 
$1: 24,000$.

Olson, J.C., 1988, Geology and ore deposits of the Cochetopa and Marshall Pass districts, Saguache and Gunnison Counties, Colorado: U.S. Geological Survey Professional Paper 1457, 44 p.

Olson, J.C., Steven T.A., and Hedlund, D.C., 1975, Geologic map of the Spring Hill Creek quadrangle, Saguache County, Colorado: U.S. Geological Survey Miscellaneous Field Studies Map MF-713, scale 1:24,000.

Olson, J.C., and Steven T.A., 1976a, Geologic map of the Sawtooth Mountain quadrangle, Saguache County, Colorado: U.S. Geological Survey Miscellaneous Field Studies Map MF-733, scale 1:24,000.

Olson, J.C., and Steven T.A., 1976b, Geologic map of the Razor Creek Dome quadrangle, Saguache County, Colorado: U.S. Geological Survey Miscellaneous Field Studies Map MF-748, scale 1:24,000.

Parat, F., 2001, Contemporaneous magmatic differentiation of S-rich trachyandesitic and high-K calc-alkaline andesite in an intracontinental setting, San Juan volcanic field, Colorado, U.S.A.: Switzerland, Universite de Geneve, Ph.D. thesis, $121 \mathrm{p}$.

Parat, F., Dungan M.A., and Lipman, P.W., 2005, Contemporaneous trachyandesitic and calc-alkaline volcanism of the Huerto Andesite, San Juan volcanic field, Colorado, USA: Journal of Petrology, v. 46, p. 859-891.

Plouff, D., and Pakiser, L.C., 1972, Gravity study in the San Juan Mountains, Colorado: U.S . Geological Survey Professional Paper 800, B183-B190.

Ratté, J.C., and Steven, T.A., 1967, Ash flows and related volcanic rocks associated with the Creede caldera, San Juan Mountains, Colorado: U.S. Geological Survey Professional Paper 524-H, 58 p.

Renne, P.R., Swisher, C.C., Deino, A.L., Karner, D.B., Owens, T.L., and DePaolo, D.J., 1998, Intercalibration of standards, absolute ages, and uncertainties in ${ }^{40} \mathrm{Ar} /{ }^{39} \mathrm{Ar}$ dating: Chemical Geology, v. 145, p. 117-152.

Riciputi, L.R., 1991, Petrology and $\mathrm{Nd}, \mathrm{Sr}$, and $\mathrm{Pb}$ isotopes of the central San Juan caldera cluster, Colorado: Madison, University of Wisconsin, PhD. dissertation.

Riciputi, L.R., Johnson, C.M., Sawyer, D.A., and Lipman, P.W., 1995, Crustal and magmatic evolution in a large multicyclic caldera complex-Isotopic evidence from the central San Juan volcanic field: Journal of Volcanology and Geothermal Research, v. 67, p. 1-28 .

Rosenbaum, J.G., Reynolds, R.L., Lipman, P.W., and Sawyer, D.A., 1987, Paleomagnetism of Oligocene ignimbrites, central San Juan Mountains, Colorado: Geological Society of America Abstracts with Programs, v. 19, p. 330.

Schmitz, M.D., and Bowring, S.A., 2001, U-Pb zircon and titanite systematics of the Fish Canyon Tuff-An assessment of high-precision $\mathrm{U}-\mathrm{Pb}$ geochronology and its application to young volcanic rocks: Geochimica et Cosmochimica Acta, v. 65, p. 2571-2587.

Seager, W.R., and McCurry, M., 1988, The cogenetic Organ cauldron and batholith, south central New MexicoEvolution of a large volume ash flow cauldron and its source magma chamber: Journal of Geophysical Research, v. 93, p. 4421-4433.

Shannon, J.R., 1988, Geology of the Mount Aetna Cauldron Complex: Golden, Colorado School of Mines, Ph.D. dissertation, $434 \mathrm{p}$.

Siems, D.F., 2000, The determination of 30 elements in geological materials by energy-dispersive X-ray fluorescence spectrometry: US. Geological Survey OpenFile Report 00-475, 13 p.

Simon, J., and Wendlandt, R.E., 1999, A petrogenetic study of the Sapinero Mesa Tuff, southwestern Colorado, USA [abs.]: Geological Society of America Abstracts with Programs, v. 31, no. 7, p. 180.

Smith, R.L., and Bailey, R.A., 1968, Resurgent cauldrons, in Coates, R.R., Hay, R.L., and Anderson, C.A., eds., Studies in volcanology: Geological Society of America Memoir 116, p. 613-662.

Steven, T.A., 1967, Geologic map of the Bristol Head quadrangle, Mineral and Hinsdale Counties, Colorado: U.S. Geological Survey Geologic Quadrangle Map GQ-631, scale 1:62,500.

Steven, T.A., 1975, Middle Tertiary volcanic field in the southern Rocky Mountains, in Curtis, B.F., ed., Cenozoic history of the southern Rocky Mountains: Geological Society of America Memoir 144, p. 75-94.

Steven, T.A., and Bieniewski, C.L., 1977, Mineral resources of the La Garita Wilderness, San Juan Mountains, southwestern Colorado: U.S. Geological Survey Bulletin $1420,65 \mathrm{p}$.

Steven, T.A., Hon, Ken, and Lanphere, M.A., 1995, Neogene geomorphic evolution of the central San Juan Mountains near Creede, Colorado: U.S. Geological Survey Miscellaneous Investigations Series Map I-2504, scale $1: 100,000$.

Steven, T.A., and Hail, W.J., 1989, Geologic map of the Montrose 30' x 60' quadrangle, southwestern Colorado: U.S. Geological Survey Miscellaneous Geologic Investigations Map I-1399, scale 1:100,000.

Steven, T.A., and Lipman, P.W., 1976, Calderas of the San Juan volcanic field, southwestern Colorado: U.S. Geological Survey Professional Paper 958, 35 p.

Steven, T.A., Lipman P.W., Hail, W.J., Jr., Barker, Fred, and Luedke, R.G., 1974, Geologic map of the Durango quadrangle, southwestern Colorado: U.S. Geological Survey Miscellaneous Geologic Investigations Map I-764, scale 1:250,000.

Steven, T.A., and Ratté, J.C., 1965, Geology and structural control of ore deposition in the Creede district, San Juan Mountains, Colorado: U.S. Geological Survey Professional Paper 487, 90 p.

Steven, T.A., and Ratté, J.C., 1973, Geologic map of the Creede quadrangle, Mineral and Saguache Counties, Colorado: U.S. Geology Survey Geologic Quadrangle Map GQ-1053, scale 1:62,500.

Stork, A., Coogan, J.C., Fillmore, R., Brunkal, H., Nicolette, J., and Payton, A., 2007, Geologic map of the Signal Peak quadrangle, Gunnison County, Colorado: Colorado 
Department of Natural Resources Open-File Report 07-03, scale 1:24,000.

Stork, A., Coogan, J.C., Fillmore, R., Csar, A., and Wentz, R., 2006, Geologic map of the Gunnison quadrangle, Gunnison County, Colorado: Colorado Department of Natural Resources Open-File Report 06-04, scale $1: 24,000$.

Taggart, Joseph E., Jr., Lindsey, J.R., Scott, B.A., Vivit, D.V., Bartel, A.J., and Stewart, K.C., 1987, Analysis of geologic materials by wavelength-dispersive X-ray fluorescence spectrometry, in Baedecker, P.A., ed., Methods for geochemical analyses: U.S. Geological Survey Professional Paper 1770, p. E1-E19.

Tanaka, H., and Kono, M., 1973, Paleomagnetism of the San Juan volcanic field, Colorado: Rock Magnetism and Paleophysics, v. 1, p. 71-76.

Turner, K.J., Young, M.D., and Wendlandt, R.F., 2003, Origin, age, and geochemistry of the tuff of Saguache Creek, southwestern Colorado [abs.]: Eos, Transactions of the American Geophysical Union, v. 84, no. 46, V51G-0365.

Tweto, O., 1979, Geologic map of Colorado: U.S. Geological Survey Special Map, 1:500,000.

Tweto, O., Steven, T.A., Hail, W.J., Jr., and Moench, R.H., 1976 , Preliminary geologic map of the Montrose $1^{\circ} \times 2^{\circ}$ quadrangle, southwestern Colorado: U.S. Geological Survey Miscellaneous Field Studies Map MF-761, scale 1:250,000.

Varga, R.J., and Smith, B.M., 1984, Evolution of the early Oligocene Bonanza caldera, northeast San Juan volcanic field, Colorado: Journal of Geophysical Research, v. 89, p. 8679-8694.

Webber, K.L., 1988, The Mammoth Mountain and Wason Park Tuffs - Magmatic evolution in the central San Juan volcanic field, southwestern Colorado: Houston, Texas, Rice University, Ph.D. dissertation, 244 p.

Whitney, J.A., Dorais, M.J., Stormer, J.C., Jr., Kline, S.W., and Matty, D.J., 1988, Magmatic conditions and development of chemical zonation in the Carpenter Ridge Tuff, central San Juan volcanic field, Colorado: American Journal of Science, v. 288-A, p. 16-44.

Whitney, J.A., and Stormer, J.C., Jr., 1985, Mineralogy, petrology, and magmatic conditions from the Fish Canyon Tuff, central San Juan volcanic field, Colorado: Journal of Petrology, v. 26, p. 726-762.

Yager, D.B., Lipman, P.W., and Sawyer, D.A., 1991, Calderarelated lava flows and intrusions of the south-central San Juan Mountains, Colorado-Analytical data: U.S. Geological Survey Open-File Report 91-313, 19 p. 
Table 1. Regional ignimbrites and calderas of the Southern Rocky Mountain Volcanic Field. (Updated and simplified from Lipman, 2007, table 1.)

\begin{tabular}{|c|c|c|c|c|c|c|}
\hline \multicolumn{5}{|c|}{ Ignimbrite } & \multicolumn{2}{|l|}{ Caldera } \\
\hline Tuff & Percent $\mathrm{SiO}_{2}$ & Rock, phenocrysts ${ }^{1}$ & $\operatorname{Vol}\left(\mathbf{k m}^{3}\right)$ & Age (Ma) & Name & Area (km) \\
\hline \multicolumn{7}{|c|}{ West San Juan Mountains } \\
\hline Sunshine Peak & Zoned, 76-68 & Qtz, sodic san & $200-500$ & 23.0 & Lake City & $15 \times 18$ \\
\hline \multicolumn{7}{|c|}{ Latir Mountains, New Mexico } \\
\hline Amalia & $76-77$ & Peralk: qtz, sodic san & 500 & 25.1 & Questa & $14 x>15$ \\
\hline \multicolumn{7}{|c|}{ Central San Juan Mountains } \\
\hline Snowshoe Mountain & $62-66$ & Xl-rich dacite & $>500$ & 26.9 & Creede & $20 \times 25$ \\
\hline \multicolumn{7}{|c|}{ Central San Juan Mountains: San Luis caldera complex } \\
\hline Nelson Mountain & Zoned, 74-63 & Xp rhy; $x l$ dacite & $>500$ & 26.9 & San Luis-Cochetopa & $9 \times 9,20 \times 25$ \\
\hline Cebolla Creek & $61-64$ & $\mathrm{Xl}$ dacite, hbl, no san & 250 & 26.9 & San Luis complex & $14 \times 16$ \\
\hline Rat Creek & Zoned, 74-65 & Xp rhy - xl dacite & 150 & 26.9 & San Luis complex & $9 \times 12$ \\
\hline Wason Park & Zoned, 72-63 & $\mathrm{Xl}$ rhyolite - dacite & $>500$ & 27.40 & South River & $20 \times 20$ \\
\hline \multicolumn{7}{|c|}{ Central San Juan Mountains } \\
\hline Blue Creek & $64-68$ & Xl dacite, no san & 250 & 27.45 & (concealed) & -- \\
\hline Carpenter Ridge & Zoned, 74-66 & Xp rhy - xl dacite & $>1,000$ & 27.55 & Bachelor & $25 \times 30$ \\
\hline \multicolumn{7}{|c|}{ West San Juan Mountains } \\
\hline Crystal Lake & $72-74$ & $\mathrm{Xp}$ rhyolite & $50-100$ & 27.6 & Silverton & $20 \times 20$ \\
\hline \multicolumn{7}{|c|}{ Central San Juan Mountains } \\
\hline Fish Canyon & $66-68$ & Xl dacite, hbl,qtz & 5000 & 28.0 & La Garita & $35 \times 75$ \\
\hline \multicolumn{7}{|c|}{ Southeast San Juan Mountains: Treasure Mountain Group } \\
\hline Chiquito Peak & $64-67$ & $\mathrm{Xl}$ dacite, sanidine & $500-1,000$ & 28.4 & Platoro & $18 \times 22$ \\
\hline \multicolumn{7}{|c|}{ Central San Juan Mountains } \\
\hline Masonic Park & $62-66$ & $\mathrm{Xl}$ dacite, no san & 500 & 28.4 & (concealed) & -- \\
\hline \multicolumn{7}{|c|}{ West San Juan Mountains } \\
\hline Sapinero Mesa & $72-75$ & Xp rhyolite & $>1,000$ & 28.3 & Uncompahgre-San Juan & $20 \times 45$ \\
\hline Dillon Mesa & $72-75$ & Xp rhyolite & $50-100$ & 28.5 & Uncompahgre? & $20 \times 20$ \\
\hline Blue Mesa & $72-74$ & Xp rhyolite & $200-500$ & 28.5 & Lost Lakes (buried) & $10 \times 10$ \\
\hline Ute Ridge & $66-68$ & $\mathrm{Xl}$ dacite, sanidine & $250-500$ & 28.6 & Ute Creek & $8 \times 8$ \\
\hline \multicolumn{7}{|c|}{ Southeast San Juan Mountains: Treasure Mountain Group } \\
\hline South Fork & $68-70$ & $\mathrm{Xl}$ dacite, sanidine & $50-100$ & 29.0 & Platoro/Summitville? & $8 \times 12 ?$ \\
\hline Ra Jadero & $64-66$ & $\mathrm{Xl}$ dacite, sanidine & 150 & 29.0 & Summitville? & $8 \times 12$ \\
\hline Ojito Creek & $67-70$ & $\mathrm{X} 1$ dacite, no san & 100 & 29.5 & Summitville? & $8 \times 12$ \\
\hline La Jara Canyon & $66-68$ & $\mathrm{X} 1$ dacite, no san & $500-1,000$ & 29.5 & Platoro & $20 \times 24$ \\
\hline Black Mountain & $67-69$ & $\mathrm{Xl}$ dacite, no san & $200-500$ & 29.9 & Platoro & -- \\
\hline \multicolumn{7}{|c|}{ Northeast San Juan Mountains } \\
\hline Saguache Creek & $73-75$ & Alkali rhyolite, no bio & $250-500$ & 32.2 & North Pass & $15 \times 17$ \\
\hline Bonanza & $74-63$ & Zoned: rhy-dac-rhy-dac & $1,000 ?$ & 33.2 & Bonanza-Gribbles & $15 \times 20$ \\
\hline \multicolumn{7}{|c|}{ North-South Sawatch Range Trend } \\
\hline Thorn Ranch & 77 & Xl rhyolite & $50-100 ?$ & 33.9 & Marshall & $10 \times 10 ?$ \\
\hline Badger Creek & $69-70$ & $\mathrm{Xl}$ dacite & $250 ?$ & 34.0 & Mount Aetna & $10 \times 15$ \\
\hline Grizzly Peak & Zoned, 77-57 & $\mathrm{X} 1$ rhy-dacite-andesite & $500 ?$ & 34.3 & Grizzly Peak & $15 \times 17$ \\
\hline Wall Mountain & $70-73$ & $\mathrm{Xl}$ rhyolite & $1,000+/-$ & 36.9 & Mount Princeton & $15 \times 30 ?$ \\
\hline
\end{tabular}

${ }^{1}$ Abbreviations: bio, biotite; dac, dacite; hbl, hornblende; qtz, quartz; rhy, rhyolite; san, sanidine; XL, crystal-rich; XP, crystal-poor 
Table 2. Summary of new ${ }^{40} \mathrm{Ar} /{ }^{39} \mathrm{Ar}$ age determinations, northeastern and central San Juan region. (See table 3 (CD-ROM) for full analytical data for individual samples. Ages were determined at New Mexico Institute of Mining and Technology, Socorro.)

\begin{tabular}{|c|c|c|c|c|c|c|}
\hline Unit $^{1,2}$ & $\begin{array}{c}\text { Material } \\
\text { Analyzed }^{2} \\
\end{array}$ & $\begin{array}{c}\text { Analysis } \\
\text { type }^{3}\end{array}$ & $\begin{array}{c}\text { No. } \\
\text { sites }\end{array}$ & Age $(\mathrm{Ma})^{4}$ & $\pm \mathrm{S}^{\mathrm{e}} / \mathbf{2 \mathbf { s } ^ { 5 }}$ & Comments \\
\hline Basalt flow & Groundmass & Plateau & 1 & 21.81 & \pm 0.21 & Overlies Carpenter Ridge Tuff \\
\hline Fisher Dacite & Sanidine & SCLF & 2 & 26.77 & 0.04 & Post-resurgence, Fisher Mountain \\
\hline Fisher Dacite & Sanidine & SCLF & 2 & 26.82 & \pm 0.05 & Pre-resurgence, west flank Snowshoe Mountain \\
\hline Snowshoe Mountain Tuff & Sanidine & SCLF & 4 & 26.87 & \pm 0.02 & Both intracaldera and outflow locations \\
\hline Baldy Cinco Dacite & Sanidine & SCLF & 4 & $25.89-26.16$ & & Section at Baldy Cinco \\
\hline Cochetopa Dome Rhyolite & Sanidine & SCLF & 8 & 26.86 & \pm 0.03 & Four lava flows and moat-tuff samples \\
\hline Intrusions of silicic rhyolite & Sanidine & SCLF & 3 & 27.10 & \pm 0.04 & Intrusions north of Cochetopa caldera \\
\hline Nelson Mountain Tuff, intracaldera & Sanidine & SCLF & 2 & 26.91 & \pm 0.04 & Small crystals \\
\hline Nelson Mountain Tuff, outflow & Sanidine & SCLF & 8 & 26.90 & \pm 0.02 & \\
\hline Dacite flow of McKenzie Mountain & Biotite & Plateau & 1 & 27.08 & \pm 0.08 & Probable precursor lava \\
\hline \multicolumn{7}{|c|}{ OLDER UNITS, INCLDUING IGNIMBRITES RELATED TO CENTRAL AND WESTERN SAN JUAN CALDERAS } \\
\hline $\begin{array}{l}\text { Wason Park Tuff } \\
\end{array}$ & Sanidine & SCLF & 5 & 27.38 & \pm 0.05 & \\
\hline Andesite of Mountain Lion Creek & Groundmass & Plateau & 3 & $27.46-27.51$ & & Overlies distal Carpenter Ridge Tuff \\
\hline Carpenter Ridge Tuff & Sanidine & SCLF & 4 & 27.55 & \pm 0.05 & \\
\hline Crystal Lake Tuff & Sanidine & SCLF & 1 & 27.41 & \pm 0.11 & Bove and others (2001): $27.62 \pm 0.07$ \\
\hline Huerto Andesite (lava flows) & $\mathrm{Hbl}$ and $\mathrm{gm}$ & Plateau & 5 & $27.64-28.32$ & & \\
\hline Fish Canyon Tuff & Sanidine & SCLF & & 28.02 & & Standard age: Renne and others (1998) \\
\hline Masonic Park Tuff & Biotite & Plateau & 1 & 28.89 & \pm 0.08 & From Lanphere (1998) \\
\hline Sapinero Mesa Tuff & Sanidine & SCLF & 4 & 28.27 & \pm 0.06 & Bove and others (2001): $28.38 \pm 0.03 \mathrm{Ma}$ \\
\hline Dillon Mesa Tuff & Sanidine & SCLF & 3 & 28.42 & \pm 0.08 & Bove and others (2001): $28.58 \pm 0.04 \mathrm{Ma}$ \\
\hline Blue Mesa Tuff & Sanidine & SCLF & 2 & 28.46 & \pm 0.04 & Bove and others (2001): $28.58 \pm 0.07 \mathrm{Ma}$ \\
\hline
\end{tabular}


Table 2. Summary of new ${ }^{40} \mathrm{Ar} /{ }^{39} \mathrm{Ar}$ age determinations.-Continued

\begin{tabular}{|c|c|c|c|c|c|c|}
\hline Unit $^{1,2}$ & $\begin{array}{c}\text { Material } \\
\text { Analyzed }^{2}\end{array}$ & $\begin{array}{c}\text { Analysis } \\
\text { type }^{3}\end{array}$ & $\begin{array}{l}\text { No. } \\
\text { sites }\end{array}$ & $\operatorname{Age~}(\mathrm{Ma})^{4}$ & $\pm \mathbf{S}^{\mathrm{e}} / \mathbf{2} \mathbf{s}^{5}$ & Comments \\
\hline \multicolumn{7}{|c|}{ LAVAS \& TUFF, EAST SIDE OF NORTH PASS CALDERA } \\
\hline Basalt of Point Benny & Groundmass & Plateau & 5 & 30.22 & \pm 0.10 & Most mafic early lava in San Juan region \\
\hline Andesite of Lone Tree Gulch & Groundmass & Plateau & 1 & 30.21 & \pm 0.17 & \\
\hline Tuff of Big Dry Gulch & Biotite & Plateau & 1 & 30.47 & \pm 0.08 & No sanidine, excess Ar biotite spectrum \\
\hline Aphanitic andesite, hill 9519 & Groundmass & Plateau & 1 & 29.98 & \pm 0.31 & \\
\hline Hornblende andesite flow, hill 9519 & Hornblende & Plateau & 1 & 30.41 & \pm 0.79 & Poor plateau \\
\hline \multicolumn{7}{|c|}{ NORTH PASS CALDERA CYCLE } \\
\hline Luders Creek Tuff & Sanidine & SCLF & 4 & 32.17 & \pm 0.04 & \\
\hline \multicolumn{7}{|l|}{ Volcanics of Cochetopa Hills } \\
\hline Dacite of East Pass Creek & Biotite & Plateau & 3 & $32.07-32.31$ & & Main area of caldera-fill flows \\
\hline Dacite of East Pass Creek (?) & Bio and hbl & Plateau & 1 & 32.82 & \pm 0.08 & At south caldera wall(?) \\
\hline Rhyolite of Taylor Canyon & Sanidine & SCLF & 1 & 32.15 & \pm 0.10 & \\
\hline Rhyolite breccia, Taylor Canyon & Sanidine & SCLF & 1 & 32.44 & \pm 0.08 & Possibly landslide breccia from a precursor flow? \\
\hline Saguache Creek Tuff & Sanidine & SCLF & 6 & 32.25 & \pm 0.05 & \\
\hline Precursor? lava flow and intrusion & Sanidine & SCLF & 2 & 32.18 & \pm 0.07 & At southeast margin of North Pass caldera \\
\hline Precursor? tuff of Spanish Creek & Sanidine & SCLF & 4 & 32.50 & \pm 0.03 & \\
\hline \multicolumn{7}{|c|}{ EARLY LAVAS, TUFFS, \& INTRUSIONS } \\
\hline Rhyolite flow, Cebolla Creek & Biotite & Plateau & 1 & 31.49 & \pm 0.14 & Below Blue Creek Tuff \\
\hline Dacite, Sawtooth Mountain & Biotite & Plateau & 1 & 32.00 & \pm 0.09 & Summit lava flow \\
\hline Porphryitic dacite, Carneros Pass & Sanidine & SCLF & 1 & 32.72 & \pm 0.09 & Highest flow (below Tfc) \\
\hline Long Branch Intrusion & Bio and hbl & Plateau & 1 & $32.98-33.01$ & & Roof zone of large pluton of porphyritic dacite \\
\hline Bonanza Tuff & Sanidine & SCLF & 1 & 33.17 & \pm 0.06 & Mean age, $33.2 \mathrm{Ma}$ (McIntosh and Chapin, 2004) \\
\hline Needle Creek Intrusion & Hornblende & Plateau & 3 & $34.28-34.42$ & & \\
\hline Hornblende-rich dike & Hornblende & Plateau & 1 & 34.61 & \pm 0.16 & Intrudes Cochetopa caldera-floor andesite \\
\hline Conejos xl dacite (san-bearing) & Sanidine & SCLF & 2 & 34.04 & \pm 0.06 & Beneath sequence of andesites \\
\hline Wall Mountain Tuff & Sanidine & SCLF & 1 & 36.85 & \pm 0.08 & Mean age, $36.9 \mathrm{Ma}$ (McIntosh and Chapin, 2004) \\
\hline
\end{tabular}

\section{${ }^{1}$ Bold type, regional ignimbrite sheets}

${ }^{2}$ Mineral abbreviations: bio, biotite; gm, groundmass separate; hbl, hornblende; san, sanidine

${ }^{3}$ Analysis type: Plateau, incremental-heating analysis; SCLF, single-crystal laser fusion

${ }^{4} \mathrm{Ages}$ for multiple samples are weighted means or ranges

${ }^{5}$ For SCLF, standard error of the weighted mean; for plateau ages, 2 s.d. ( $95 \%$ confidence level) 
Table 4. Representative chemical analyses for Tertiary volcanic rocks, northeastern San Juan Mountains, southwestern Colorado. determined by WDXRF (Taggart and others, 1987); minor elements were by EDXRF methods (Siems, 2000).

[Abbreviations: bio, biotite; hbl, hornblende; pl, plagioclase; san, sanidine; Cr, Creek; Hwy, Highway; Mtn, Mountain; Tfc, Fish Canyon Tuff]

\begin{tabular}{|c|c|c|c|c|c|c|c|c|c|c|c|c|c|}
\hline \multirow{2}{*}{ Lithology, location } & \multirow{2}{*}{$\begin{array}{l}\text { Unit } \\
\text { label }\end{array}$} & \multirow{2}{*}{$\begin{array}{c}\text { Sample } \\
\text { No. }\end{array}$} & \multicolumn{2}{|c|}{ Latitude } & \multicolumn{2}{|c|}{ Longitude } & \multicolumn{7}{|c|}{ X-ray fluorescence (WDXRF); weight \% (calculated to } \\
\hline & & & Deg & Min & Deg & Min & $\mathrm{SiO}_{2}$ & $\mathrm{TiO}_{2}$ & $\mathrm{Al}_{2} \mathrm{O}_{3}$ & $\mathrm{FeTO}_{3}$ & MgO & $\mathrm{CaO}$ & $\mathrm{Na}_{2} \mathrm{O}$ \\
\hline \multicolumn{14}{|l|}{ Hinsdale Formation (21.8-27.5 Ma) } \\
\hline Lava, Powderhorn trail & Thb & $98 \mathrm{~L}-22$ & 38 & 4.67 & 107 & 6.88 & 54.45 & 1.57 & 15.89 & 8.55 & 3.61 & 6.66 & 4.15 \\
\hline Basaltic andesite lava flow, Houghland Hill & Thb & $00 \mathrm{~L}-1$ & 38 & 7.43 & 106 & 17.68 & 50.14 & 1.86 & 14.83 & 11.53 & 7.30 & 8.03 & 2.99 \\
\hline \multicolumn{14}{|l|}{ Cochetopa Dome Rhyolite (26.9 Ma) } \\
\hline Apache tears, base, upper flow & Tcdu & 00L-31-A & 38 & 13.55 & 106 & 43.92 & 76.31 & 0.11 & 12.79 & 0.82 & $<0.10$ & 0.41 & 3.75 \\
\hline Fine-grain crystal-rich flow & Tcdc & $01 \mathrm{~L}-25$ & 38 & 12.92 & 106 & 42.88 & 76.48 & 0.09 & 13.00 & 0.71 & $<0.10$ & 0.32 & 4.27 \\
\hline Middle flow, lower part & Tcdm & $01 \mathrm{~L}-27$ & 38 & 12.60 & 106 & 43.00 & 76.44 & 0.11 & 12.89 & 0.83 & $<0.10$ & 0.46 & 4.08 \\
\hline Lower flow, east side & Tcdl & $00 \mathrm{~L}-33$ & 38 & 12.83 & 106 & 40.55 & 75.84 & 0.13 & 13.01 & 0.81 & $<0.10$ & 0.53 & 3.89 \\
\hline \multicolumn{14}{|l|}{ Andesite of Mountain Lion Creek } \\
\hline Basaltic andesite, Hat Mountain & Tal & 03L-10 & 38 & 1.57 & 106 & 31.70 & 61.28 & 0.86 & 15.37 & 5.63 & 2.24 & 4.74 & 4.27 \\
\hline \multicolumn{14}{|l|}{ Carpenter Ridge Tuff (27.5 Ma) } \\
\hline Devitrified interior, roadcut Hwy 114 & Tcr & 02L-20-A & 38 & 10.48 & 106 & 28.63 & 75.11 & 0.21 & 13.11 & 1.26 & 0.08 & 0.75 & 3.49 \\
\hline Clast landslide breccia, Samora Creek & Tcr & $02 \mathrm{~L}-3$ & 38 & 14.25 & 106 & 38.33 & 74.44 & 0.23 & 13.53 & 1.40 & 0.07 & 0.89 & 3.66 \\
\hline \multicolumn{14}{|l|}{ Huerto Formation } \\
\hline Dacite flow, Trickle Mtn & Thu & 02L-58 & 38 & 9.12 & 106 & 23.42 & 62.42 & 0.89 & 15.78 & 5.06 & 1.50 & 3.45 & 4.44 \\
\hline Dacite flow, south side Spruce Mtn & Thu & $05 \mathrm{~L}-46$ & 38 & 1.12 & 106 & 21.51 & 63.63 & 0.82 & 15.30 & 5.24 & 1.48 & 3.49 & 3.99 \\
\hline Andesite flow, lower, east Mount Lion & Thu & $03 \mathrm{~L}-44 \mathrm{~A}$ & 38 & 3.67 & 106 & 23.50 & 56.87 & 1.20 & 15.73 & 7.70 & 2.95 & 5.99 & 4.03 \\
\hline \multicolumn{14}{|l|}{ Sapinero Mesa Tuff (28.25 Ma) } \\
\hline Los Pinos Cr road, distal, most dense welded & Tws & 00L-21B & 38 & 11.87 & 106 & 50.87 & 75.14 & 0.26 & 12.66 & 1.46 & 0.22 & 1.07 & 3.13 \\
\hline Partly welded distal tuff, Houselog Creek & Tws & $03 \mathrm{~L}-45$ & 38 & 5.93 & 106 & 21.95 & 73.54 & 0.27 & 13.67 & 1.41 & 0.19 & 0.77 & 3.30 \\
\hline \multicolumn{14}{|l|}{ Pre-FCT flows and tuffs $(\sim 30 \mathrm{Ma})$} \\
\hline Andesite, dike, Point Benny & Tbpv & $03 \mathrm{~L}-42$ & 38 & 10.07 & 106 & 32.77 & 52.00 & 1.75 & 16.22 & 9.65 & 4.21 & 7.47 & 3.71 \\
\hline Andesite of Lone Tree Gulch & Tla & $05 \mathrm{~L}-40$ & 38 & 9.38 & 106 & 22.41 & 59.01 & 1.18 & 16.29 & 7.67 & 1.49 & 4.68 & 4.02 \\
\hline Tuff of Big Dry Gulch & Tbg & 03L-1 & 38 & 9.70 & 106 & 24.60 & 67.11 & 0.60 & 16.43 & 3.01 & 1.21 & 2.34 & 2.39 \\
\hline
\end{tabular}

\section{NORTH PASS CALDERA CYCLE}

\section{Luders Creek Tuff (32.2 Ma)}

Crystal-rich dense welded upper tuff, Luders $\mathrm{Cr} \quad \mathrm{T}$ Crystal-poor part welded lower tuff, Luders $\mathrm{Cr} \quad \mathrm{TI}$

\section{Volcanics of Cochetopa Hills \\ Dacite of East Pass Creek (32.2 Ma) \\ Dacite flow, North Pass \\ Dacite flow, Luders Creek \\ Bio-hbl dacite flow, Fourmile Creek \\ Caldera-related rhyolite lava flows \\ Crystal-poor rhyolite, Corduroy Creek \\ Crystal-poor rhyolite, Benny Creek}

\section{Saguache Creek Tuff (32.25 Ma)}

Upper welding zone, Pine Creek

Above Bonanza Tuff, Cross Creek

Densely welded rhyolite, Saguache Park

Lower crystal-rich dark phase, Bear Creek

Densely welded rhyolite tuff, Soldier Park

Precursor tuff of Spanish Creek(32.5 Ma)

Densely welded crystal-rich rhyolite, Spanish Creek Tts

Densely welded crystal-rich rhyolite, Spanish Creek Tts

Tnp
Tsc

Tsc

Tsc

Tsc

Tsc

Tld $\quad$ 02L-26 $\quad 38 \quad 10.15 \quad 106 \quad 34.93 \quad 66.93$

$\begin{array}{lllllll}\text { TIr } & 02 \mathrm{~L}-28 & 38 & 9.97 & 106 & 35.52 & 72.50\end{array}$

0.36

$0.57 \quad 1.74 \quad 4.59$

$02 \mathrm{~L}-28$

$\begin{array}{lllllll} & 03 \mathrm{~L}-26 & 38 & 11.80 & 106 & 32.28 & 61.40\end{array}$

$\begin{array}{llllllll}\text { Tnpd } & 03 \mathrm{~L}-41 & 38 & 14.38 & 106 & 35.15 & 65.95\end{array}$

$\begin{array}{llllllll}\text { Tnpd? } & 05 \mathrm{~L}-3 & 38 & 10.58 & 106 & 34.37 & 65.57\end{array}$

$0.74 \quad 17.11$

$0.51-16.03-2.96$

$0.49 \quad 17.57 \quad 3.69$

1.89

4.46

$\begin{array}{lllllll}\text { Tnpr } & \text { 04L-4 } & 38 & 10.57 & 106 & 36.52 & 76.95\end{array}$

$\begin{array}{llllll}0.18 & 12.42 & 0.46 & <0.10 & 0.46 & 3.42\end{array}$

$\begin{array}{lllllll}05 \mathrm{~L}-43 & 38 & 10.67 & 106 & 33.57 & 75.03\end{array}$

$0.19 \quad 12.89 \quad 1.05$

$<0.10$

$0.53 \quad 4.01$

$\begin{array}{llllll}00 \mathrm{~L}-24 & 38 & 12.40 & 106 & 36.42 & 72.41\end{array}$

$\begin{array}{lllllll}02 \mathrm{~L}-24 & 38 & 11.73 & 106 & 19.83 & 73.62\end{array}$

$\begin{array}{lllllll}02 \mathrm{~L}-32 & 38 & 2.12 & 106 & 38.38 & 74.45\end{array}$

$\begin{array}{llllll}02 \mathrm{~L}-11 & 38 & 13.48 & 106 & 29.25 & 73.72\end{array}$

$\begin{array}{llllll}02 \mathrm{~L}-33 & 38 & 22.47 & 106 & 52.82 & 72.98\end{array}$
$0.22 \quad 14.75$

$0.23 \quad 13.9$

0.21

0.21

0.23
4.75

13.94

13.78

13.90
$<0.10$

0.15

0.13

0.14

0.10 $\begin{array}{llllll}\text { 02L-34-A } & 38 & 14.50 & 106 & 32.55 & 73.00\end{array}$ $\begin{array}{llllll}\text { 02L-34-B } & 38 & 14.70 & 106 & 32.63 & 75.13\end{array}$
$0.24 \quad 14.37 \quad 1.79$

$0.31=1.10-3.46$ 


\begin{tabular}{|c|c|c|c|c|c|c|c|c|c|c|c|c|c|c|c|c|c|c|c|c|}
\hline \multicolumn{5}{|c|}{ reported total without $\mathrm{LOI}$ ) } & \multicolumn{16}{|c|}{ EDXRF, ppm } \\
\hline $\mathrm{K}_{2} \mathrm{O}$ & $\mathrm{P}_{2} \mathrm{O}_{5}$ & MnO & LOI & Total & $\mathbf{Z n}$ & $\mathbf{R b}$ & $\mathrm{Sr}$ & $\mathbf{Y}$ & $\mathbf{Z r}$ & Nb & $\mathbf{P b}$ & Th & $\mathbf{B a}$ & $\mathbf{L a}$ & $\mathrm{Ce}$ & Nd & $\mathbf{V}$ & $\mathrm{Cr}$ & Ga & Ni \\
\hline 3.45 & 0.71 & 0.12 & 1.94 & 99.16 & 112 & 84 & 996 & 24 & 283 & 27 & & & 1340 & & & & & & & 84 \\
\hline 2.68 & 0.49 & 0.14 & 2.87 & 99.99 & 101 & 53 & 653 & 21 & 160 & 21 & 5 & $<2$ & 686 & 23 & 54 & 26 & 220 & 225 & 22 & 140 \\
\hline 5.47 & $<0.05$ & 0.11 & 0.67 & 99.76 & 58 & 206 & $<2$ & 23 & 131 & 31 & 32 & 17 & 8 & 37 & 67 & 26 & 12 & 4 & 20 & $<2$ \\
\hline 4.61 & $<0.05$ & 0.22 & 0.75 & 299.50 & 52 & 251 & 10 & 19 & 111 & 36 & 34 & 22 & 127 & 38 & 63 & 24 & 6 & $<3$ & 19 & 3 \\
\hline 4.71 & $<0.05$ & 0.08 & 0.71 & 299.21 & 60 & 189 & 10 & 21 & 127 & 25 & 29 & 14 & 28 & 40 & 74 & 27 & 15 & 5 & 17 & 3 \\
\hline 5.09 & $<0.05$ & 0.05 & 0.84 & 99.36 & 32 & 178 & 26 & 17 & 133 & 23 & 31 & 12 & 105 & 56 & 103 & 33 & 7 & $<3$ & 19 & $<2$ \\
\hline 4.08 & 0.57 & 0.08 & 0.45 & 99.12 & 98 & 88 & 1130 & 17 & 317 & 20 & 19 & 8 & 2010 & 92 & 154 & 79 & 116 & 65 & 24 & 30 \\
\hline 5.40 & 0.19 & 0.08 & 0.81 & 99.68 & 42 & 156 & 80 & 25 & 201 & 19 & 23 & 19 & 470 & 59 & 102 & 42 & 18 & $<3$ & 15 & 7 \\
\hline 5.31 & 0.22 & 0.08 & 0.99 & 99.84 & 43 & 152 & 103 & 26 & 209 & 20 & 26 & 18 & 552 & 57 & 105 & 37 & 19 & $<3$ & 16 & 5 \\
\hline 4.66 & 0.65 & 0.07 & 0.50 & 98.92 & 97 & 112 & 1060 & 15 & 426 & 35 & 21 & 8 & 2180 & 111 & 182 & 88 & 88 & 10 & 24 & 14 \\
\hline 4.35 & 0.44 & 0.09 & 0.67 & 98.83 & 82 & 105 & 767 & 13 & 292 & 20 & 14 & $<4$ & 1860 & 97 & 158 & 102 & 96 & 41 & 16 & 5 \\
\hline 4.12 & 0.70 & 0.11 & 0.82 & 99.41 & 98 & 85 & 1210 & 18 & 265 & 23 & 14 & 6 & 1810 & 74 & 130 & 65 & 148 & 155 & 22 & 56 \\
\hline 5.11 & 0.08 & 0.05 & 2.03 & 99.19 & 41 & 123 & 190 & 24 & 230 & 20 & 22 & 22 & 1130 & 62 & 106 & 47 & 24 & 3 & 14 & 3 \\
\hline 6.05 & 0.07 & 0.05 & 1.27 & 99.33 & 35 & 144 & 142 & 24 & 247 & 22 & 26 & 26 & 1050 & 70 & 105 & 39 & 25 & 5 & 15 & 4 \\
\hline 3.45 & 0.75 & 0.13 & 1.33 & 99.33 & 108 & 64 & 1190 & 24 & 204 & 24 & 11 & $<4$ & 1420 & 51 & 96 & 56 & 236 & 85 & 23 & 45 \\
\hline 3.45 & 0.58 & 0.18 & 2.35 & 98.55 & 92 & 67 & 1010 & 17 & 255 & 18 & 10 & $<4$ & 1860 & 67 & 125 & 75 & 153 & 47 & 18 & 20 \\
\hline 6.07 & 0.15 & 0.10 & 6.23 & 99.39 & 65 & 143 & 332 & 32 & 365 & 19 & 20 & 15 & 979 & 54 & 101 & 48 & 36 & $<5$ & 17 & 5 \\
\hline
\end{tabular}

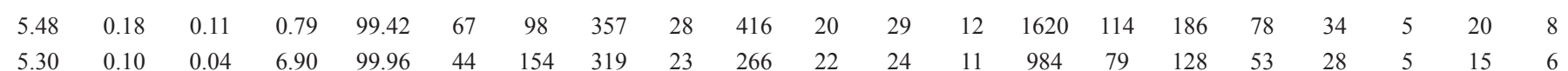

\begin{tabular}{|c|c|c|c|c|c|c|c|c|c|c|c|c|c|c|c|c|c|c|c|}
\hline 4.09 & 0.38 & 0.10 & 1.79 & 99.54 & 74 & 87 & 875 & 24 & 267 & 18 & 24 & 10 & 1540 & 66 & 106 & 54 & 101 & 8 & 19 \\
\hline 4.57 & 0.22 & 0.07 & 0.81 & 97.77 & 57 & 99 & 609 & 26 & 264 & 20 & 27 & 12 & 1620 & 82 & 121 & 62 & 61 & 5 & 19 \\
\hline 4.96 & 0.09 & 0.08 & 0.70 & 98.83 & 39 & 123 & 32 & 22 & 201 & 25 & 26 & 10 & 309 & 85 & 146 & 65 & 29 & $<5$ & 11 \\
\hline 5.34 & 0.09 & 0.04 & 1.28 & 100.14 & 73 & 124 & 43 & 28 & 272 & 24 & 28 & 12 & 365 & 88 & 147 & 51 & 14 & $<3$ & 17 \\
\hline 5.32 & 0.09 & 0.06 & 0.70 & 99.53 & 70 & 124 & 42 & 33 & 292 & 27 & 30 & 14 & 307 & 90 & 158 & 71 & 18 & $<3$ & 17 \\
\hline 5.38 & 0.08 & 0.04 & 1.07 & 99.77 & 48 & 123 & 64 & 39 & 295 & 27 & 21 & 14 & 459 & 107 & 151 & 77 & 16 & $<3$ & 16 \\
\hline
\end{tabular}


Table 4. Representative chemical analyses for Tertiary volcanic rocks.-Continued

\begin{tabular}{|c|c|c|c|c|c|c|c|c|c|c|c|c|c|}
\hline \multirow{2}{*}{ Lithology, location } & \multirow{2}{*}{$\begin{array}{l}\text { Unit } \\
\text { label }\end{array}$} & \multirow{2}{*}{$\begin{array}{c}\text { Sample } \\
\text { No. }\end{array}$} & \multicolumn{2}{|c|}{ Latitude } & \multicolumn{2}{|c|}{ Longitude } & \multicolumn{7}{|c|}{ X-Ray Fluorescence (WDXRF); weight \% (calculated to } \\
\hline & & & Deg & Min & Deg & Min & $\mathrm{SiO}_{2}$ & $\mathrm{TiO}_{2}$ & $\mathrm{Al}_{2} \mathrm{O}_{3}$ & $\mathrm{FeTO}_{3}$ & MgO & $\mathrm{CaO}$ & $\mathrm{Na}_{2} \mathrm{O}$ \\
\hline \multicolumn{14}{|l|}{ OLDER NORTHEASTERN TUFFS \& LAVAS } \\
\hline \multicolumn{14}{|l|}{ Bonanza Tuff (33.2 ma) } \\
\hline Densely welded interior "upper" tuff, Poison Gulch & Tbd & 02L-21-B & 38 & 9.30 & 106 & 16.33 & 73.73 & 0.22 & 12.70 & 1.34 & 0.19 & 2.89 & 3.78 \\
\hline Vitrophyric lower dacite, Findley ridge area & Tbd & 02L-22-B & 38 & 9.23 & 106 & 16.30 & 64.28 & 0.74 & 17.31 & 3.87 & 1.03 & 2.95 & 3.83 \\
\hline \multicolumn{14}{|l|}{ Conejos Formantion (including Rawley Andesite) } \\
\hline \multicolumn{14}{|l|}{ Cebolla-Los Pinos Creeks } \\
\hline Flow-laminated interior, large flow, Cebolla Creek & Tcfr & $95 \mathrm{~L}-5$ & 38 & 6.63 & 107 & 1.88 & 73.47 & 0.20 & 14.15 & 0.83 & 0.24 & 1.22 & 3.81 \\
\hline Flow-laminated dacite lava, Los Pinos Pass & Tcd & 99L-3 & 38 & 6.58 & 106 & 58.17 & 65.68 & 0.74 & 16.90 & 3.71 & 0.61 & 3.16 & 4.23 \\
\hline \multicolumn{14}{|l|}{ Cochetopa Park area } \\
\hline \multicolumn{14}{|l|}{$\underline{\text { Intrusions }}$} \\
\hline Hornblende-rich dike (Conejos), Hwy 114 & Tci & 03L-31 & 38 & 17.25 & 106 & 45.00 & 56.94 & 1.06 & 16.37 & 8.35 & 3.61 & 5.95 & 3.63 \\
\hline Granodiorite intrusion, upper Needle Creek & Tci & 03L-17 & 38 & 19.70 & 106 & 34.12 & 59.97 & 0.78 & 16.52 & 6.52 & 2.67 & 5.39 & 3.90 \\
\hline Bio-hbl intrusion, Left Hand Needle Creek & Tci & $05 \mathrm{~L}-12$ & 38 & 20.62 & 106 & 31.78 & 61.98 & 0.69 & 16.51 & 5.43 & 1.68 & 4.19 & 4.02 \\
\hline Dike, Needle Rock & Tci & 03L-20A & 38 & 21.53 & 106 & 33.17 & 60.06 & 0.87 & 16.31 & 6.85 & 2.69 & 4.95 & 3.91 \\
\hline Hbl-bio-pl dike, Barret Creek & Tci & $05 \mathrm{~L}-15$ & 38 & 22.69 & 106 & 35.40 & 59.19 & 0.85 & 16.56 & 6.88 & 2.92 & 5.16 & 3.71 \\
\hline \multicolumn{14}{|l|}{$\underline{\text { Lava flows }}$} \\
\hline Crystal-poor rhyolite, Green Mountain & Tbfa & 04L-21 & 38 & 8.33 & 106 & 21.15 & 76.13 & 0.12 & 12.69 & 0.90 & $<0.10$ & 0.93 & 3.48 \\
\hline Crystal-rich rhyolite flow, Barret Creek & Tbfc & 04L-5 & 38 & 10.57 & 106 & 36.52 & 74.28 & 0.24 & 13.45 & 1.56 & 0.43 & 1.23 & 2.89 \\
\hline Quartz-rich rhyolite, south of Spanish Creek & Tcfr & $02 \mathrm{~L}-13$ & 38 & 13.45 & 106 & 31.42 & 73.15 & 0.25 & 14.11 & 1.77 & 0.39 & 1.43 & 3.84 \\
\hline Dacite flow, Luhan Creek (Tfc mineralogy) & Tcd & 01L-10 & 38 & 15.05 & 106 & 34.10 & 70.96 & 0.29 & 15.32 & 2.12 & 0.38 & 1.59 & 4.06 \\
\hline Coarse porph dacite (san), south of Carnero Pass & Tcd & $05 \mathrm{~L}-45$ & 37 & 59.73 & 106 & 25.99 & 65.57 & 0.70 & 15.30 & 4.60 & 1.13 & 2.93 & 3.59 \\
\hline Dacite lava, Sawtooth Mtn, top flow & Tcd & 01L-29 & 38 & 16.43 & 106 & 51.90 & 63.20 & 0.72 & 16.21 & 5.67 & 2.00 & 4.20 & 3.56 \\
\hline Fine-grain andesite, summit Razor Creek Dome & Tca & 01L-19 & 38 & 18.97 & 106 & 42.95 & 60.59 & 0.84 & 16.63 & 6.79 & 2.08 & 5.08 & 4.04 \\
\hline Dense aphyric mafic lava, Middle Baldy & Tca & 02L-38 & 38 & 18.88 & 106 & 29.88 & 57.11 & 1.10 & 15.89 & 8.00 & 3.71 & 6.28 & 3.60 \\
\hline Olivine-rich mafic lava, Middle Baldy & Tca & 02L-39 & 38 & 18.87 & 106 & 30.30 & 53.12 & 1.06 & 15.08 & 9.44 & 7.36 & 8.16 & 3.13 \\
\hline \multicolumn{14}{|l|}{ Wall Mountain Tuff (36.9 Ma) } \\
\hline Rheomorphic tuff, Alkali Creek & Twn & 01L-22 & 38 & 17.72 & 106 & 46.63 & 74.68 & 0.41 & 13.71 & 1.57 & 0.31 & 0.53 & 2.22 \\
\hline Rheomorphic tuff, Bead Creek & Twn & 01L-30 & 38 & 20.12 & 106 & 50.30 & 69.90 & 0.50 & 15.48 & 2.19 & 0.30 & 1.25 & 3.68 \\
\hline
\end{tabular}




\begin{tabular}{|c|c|c|c|c|c|c|c|c|c|c|c|c|c|c|c|c|c|c|c|c|}
\hline \multicolumn{5}{|c|}{ reported total without $\mathrm{LOI}$ ) } & \multicolumn{16}{|c|}{ EDXRF, ppm } \\
\hline $\mathrm{K}_{2} \mathrm{O}$ & $\mathbf{P}_{2} \mathbf{O}_{5}$ & MnO & LOI & Total & $\mathbf{Z n}$ & $\mathbf{R b}$ & $\mathrm{Sr}$ & $\mathbf{Y}$ & $\mathbf{Z r}$ & $\mathrm{Nb}$ & $\mathbf{P b}$ & Th & $\mathbf{B a}$ & La & $\mathrm{Ce}$ & Nd & $\mathbf{V}$ & $\mathrm{Cr}$ & Ga & $\mathbf{N i}$ \\
\hline 5.10 & 0.09 & 0.03 & 3.16 & 100.07 & 39 & 237 & 82 & 26 & 202 & 46 & 24 & 52 & 106 & 68 & 108 & 30 & 16 & 4 & 16 & 7 \\
\hline 5.16 & 0.31 & 0.05 & 1.21 & 99.53 & 77 & 126 & 659 & 30 & 528 & 25 & 25 & 21 & 1720 & 101 & 183 & 92 & 76 & 6 & 21 & 9 \\
\hline 4.59 & 0.08 & 0.06 & 0.71 & 98.66 & & & & & & & & & & & & & & & & \\
\hline 4.23 & 0.30 & 0.07 & 1.19 & 99.64 & & & & & & & & & & & & & & & & \\
\hline 3.00 & 0.52 & 0.11 & 1.65 & 99.54 & 95 & 58 & 958 & 23 & 216 & 13 & 18 & 7 & 1260 & 46 & 81 & 43 & 163 & 47 & 22 & 26 \\
\hline 3.19 & 0.36 & 0.12 & 1.94 & 99.41 & 77 & 61 & 865 & 22 & 221 & 19 & 21 & 5 & 1540 & 58 & 97 & 56 & 109 & 26 & 22 & 14 \\
\hline 3.67 & 0.44 & 0.11 & 1.24 & 98.71 & 80 & 67 & 985 & 22 & 264 & 12 & 17 & $<4$ & 2250 & 68 & 114 & 82 & 88 & 18 & 17 & 3 \\
\hline 3.22 & 0.41 & 0.08 & 1.26 & 99.35 & 84 & 56 & 918 & 23 & 212 & 11 & 20 & 6 & 1620 & 48 & 85 & 49 & 131 & 36 & 21 & 20 \\
\hline 3.08 & 0.49 & 0.20 & 2.16 & 99.05 & 75 & 56 & 882 & 25 & 281 & 14 & 14 & $<4$ & 1710 & 47 & 97 & 68 & 112 & 19 & 16 & 3 \\
\hline 4.47 & 0.05 & 0.04 & 0.69 & 98.81 & 32 & 98 & 203 & 15 & 111 & 27 & 29 & $<4$ & 1300 & 62 & 89 & 61 & 13 & $<1.1$ & 16 & $<0.6$ \\
\hline 4.95 & 0.08 & 0.04 & 1.84 & 99.12 & 21 & 117 & 29 & 30 & 248 & 56 & 24 & 11 & 289 & 86 & 149 & 5 & 14 & inf & 15 & 24 \\
\hline 4.60 & 0.14 & 0.05 & 0.75 & 99.74 & 39 & 102 & 301 & 15 & 183 & 15 & 26 & 9 & 972 & 52 & 87 & 45 & 21 & 9 & 17 & 6 \\
\hline 4.74 & 0.12 & 0.05 & 0.79 & 99.64 & 79 & 104 & 363 & 15 & 193 & 17 & 26 & 8 & 1110 & 49 & 79 & 34 & 26 & 9 & 18 & 3 \\
\hline 4.79 & 0.27 & 0.08 & 1.32 & 98.96 & 51 & 126 & 478 & 33 & 317 & 22 & 17 & 8 & 1210 & 74 & 137 & 68 & 99 & 87 & 14 & 3 \\
\hline 3.93 & 0.33 & 0.10 & 1.89 & 99.91 & 72 & 96 & 775 & 23 & 223 & 15 & 24 & 12 & 1390 & 49 & 91 & 51 & 86 & 19 & 19 & 12 \\
\hline 2.97 & 0.40 & 0.10 & 0.80 & 99.53 & 84 & 58 & 980 & 22 & 214 & 12 & 16 & 7 & 1540 & 49 & 90 & 57 & 107 & 42 & 21 & 18 \\
\hline 3.28 & 0.64 & 0.12 & 0.54 & 99.73 & 101 & 73 & 1180 & 28 & 318 & 24 & 20 & 15 & 1420 & 75 & 136 & 66 & 167 & 56 & 24 & 44 \\
\hline 1.94 & 0.41 & 0.14 & 1.16 & 99.84 & 92 & 34 & 769 & 24 & 155 & 12 & 8 & $<2$ & 954 & 25 & 55 & 46 & 197 & 610 & 18 & 211 \\
\hline 6.15 & 0.07 & 0.03 & 2.24 & 99.67 & 32 & 184 & 158 & 29 & 383 & 22 & 29 & 35 & 1580 & 100 & 161 & 77 & 30 & 7 & 15 & 5 \\
\hline 6.08 & 0.10 & 0.04 & 1.13 & 99.53 & 53 & 195 & 250 & 41 & 482 & 31 & 40 & 42 & 1520 & 135 & 197 & 108 & 32 & 5 & 19 & 5 \\
\hline
\end{tabular}


Table 6. Megascopic characteristic features, major ignimbrite sheets in the central and northeastern San Juan region.

\begin{tabular}{|c|c|c|}
\hline Ignmbrite sheet $^{1}$ & Composition ${ }^{2}$ & Textures and phenocrysts ${ }^{3}$ \\
\hline Snowshoe Mountain Tuff & Mafic dacite & Phenocryst rich; densely welded within caldera, weakly welded outflow \\
\hline Nelson Mountain Tuff & Low-Si rhyolite $\Rightarrow$ dacite & Compositionally zoned; weakly welded crystal-poor to dense crystal-rich \\
\hline Cebolla Creek Tuff & Mafic dacite & Typically weakly welded; abundant hornblende $>>$ augite is distinctive \\
\hline Rat Creek Tuff & Low-Si rhyolite $\Rightarrow$ dacite & Compositionally zoned; weakly welded rhyolite to dense dacite \\
\hline Wason Park Tuff & Rhyolite & Phenocryst-rich rhyolite; tabular sanidine phenocrysts \\
\hline Blue Creek Tuff & Dacite & Phenocryst rich; sanidine is absent (contrast with Mammoth Mountain Member) \\
\hline \multicolumn{3}{|l|}{ Carpenter Ridge Tuff } \\
\hline Mammoth Mountain Member (upper) & Dacite & Phenocryst rich; sanidine is common (contrast with Blue Creek Tuff) \\
\hline Outflow and lower intracaldera tuff & Low-Si rhyolite & Phenocryst-poor; common basal vitrophyre, central lithophysal zone \\
\hline Crystal Lake Tuff & Low-Si rhyolite & Similar to rhyolitic Carpenter Ridge Tuff, but less welded within map area \\
\hline Fish Canyon Tuff & Dacite & Distinctive light-gray, phenocryst-rich; resorbed quartz, hornblende, absence of augite \\
\hline Sapinero Mesa Tuff & Low-Si rhyolite & Similar to rhyolitic Carpenter Ridge Tuff, but generally less welded within map area \\
\hline Dillon Mesa Tuff & Low-Si rhyolite & Similar to rhyolitic Carpenter Ridge Tuff, but generally less welded within map area \\
\hline Blue Mesa Tuff & Low-Si rhyolite & Similar to rhyolitic Carpenter Ridge Tuff, but generally less welded within map area \\
\hline Ute Ridge Tuff & Dacite & Phenocryst-rich; contains sparse sanidine (in contrast to Masonic Park Tuff) \\
\hline Masonic Park Tuff & Dacite & Phenocrysts similar to Blue Creek Tuff; typically less welded \\
\hline Luders Creek Tuff & Low-Si rhyolite $\Rightarrow$ dacite & Compositionally zoned; resembles Nelson Mountain Tuff \\
\hline Saguache Creek Tuff & Low-Si rhyolite & Resembles Carpenter Ridge and Sapinero Mesa Tuffs, but lacks phenocrystic biotite \\
\hline Bonanza Tuff & Zoned complexly & Local basal xl-poor rhyolite, lower $\mathrm{xl}$ dacite, upper rhyolite, local upper xl dacite \\
\hline Badger Creek Tuff & Dacite & Crystal rich; resembles Fish Canyon Tuff \\
\hline Wall Mountain Tuff & Rhyolite & Crystal-rich, large blocky sanidine; locally complexly rheomorphic \\
\hline
\end{tabular}

${ }^{1}$ Bold type, ignimbrite sheets of Cochetopa-North Pass area

${ }^{2} \mathrm{Si}, \mathrm{SiO}_{2}$

${ }^{3} \mathrm{xl}$, crystal 